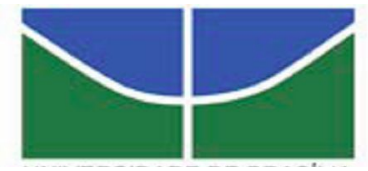

UNIVERSIDADE DE BRASÍLIA

Centro de Excelência em Turismo

Pós-graduação Lato Sensu

Curso de Especialização em Gestão de Negócios em Turismo

\title{
ESTUDO DE CASO: PERCEPÇÃO DOS COLABORADORES DA EMBRATUR EM RELAÇÃO AOS PROGRAMAS DE QUALIDADE DE VIDA NO TRABALHO.
}

Juliana Loreto Carvalheira 
UNIVERSIDADE DE BRASÍLIA

Centro de Excelência em Turismo

Pós-graduação Lato Sensu

Curso de Especialização em Gestão de Negócios em Turismo

\section{ESTUDO DE CASO: PERCEPÇÃO DOS COLABORADORES DA EMBRATUR EM RELAÇÃO AOS PROGRAMAS DE QUALIDADE DE VIDA NO TRABALHO.}

\section{Juliana Loreto Carvalheira}

Prof ${ }^{a}$ Shirley Pontes, Msc.

Orientador

Monografia apresentada ao Centro de Excelência em turismo - CET, da Universidade de Brasília - UnB, como requisito parcial à obtenção do grau de Especialista em Gestão de Negócios em Turismo. 
Carvalheira, Juliana Loreto.

Estudo de Caso: Percepção dos colaboradores da Embratur em relação aos programas de Qualidade de Vida no Trabalho / Juliana Loreto Carvalheira

x; 83 fls: il.

Trabalho de Conclusão do Curso de Pós-graduação lato sensu em Gestão de Negócios em Turismo

Brasília - DF, julho de 2007.

Orientador(a): Shirley Pontes, Msc.

1. Gestão de pessoas 2. Qualidade de vida no trabalho 3. Funcionários 4. EMBRATUR, 5. Título 


\section{UNIVERSIDADE DE BRASÍLIA}

Centro de Excelência em Turismo

Pós-graduação Lato Sensu

Curso de Especialização em Gestão de Negócios em Turismo

Monografia apresentada ao Centro de Excelência em turismo - CET, da Universidade de Brasília - UnB, como requisito parcial à obtenção do grau de Especialista em Gestão de Negócios em Turismo.

Juliana Loreto Carvalheira

Aprovado por:

Professor(a) Shirley Pontes, Msc Orientadora.

Professor (a) Domingos Spézia, Msc.

Professor (a) Gilson Borda, Dr.

Brasília, junho de 2007 


\section{DEDICATÓRIA}

Dedico esta nova conquista à toda minha família, e, especialmente, à minha mãe, Rosa Helena, por todo apoio e força que me ofereceu ao longo deste período. 


\section{AGRADECIMENTOS}

Agradeço aos professores, orientadores, minha família, amigos e a todos os funcionários da EMBRATUR, que, mesmo com os seus afazeres me ajudaram a realizar esta pesquisa. 


\section{RESUMO}

Atualmente, a avaliação dos resultados de Gestão de Pessoas é um dos temas mais desafiadores para esta área, e vem recebendo investimentos cada vez maiores. Nas questões relacionadas à Gestão dos Programas de Qualidade de Vida no Trabalho (QVT), muitas expectativas de resultados são levantadas quando se trata de melhorar o bem-estar das pessoas em seu ambiente profissional, o que influencia, direta ou indiretamente, a produtividade e os resultados financeiros da organização. Nesta pesquisa estuda-se a percepção dos colaboradores sobre os benefícios deste na EMBRATUR, levando-se em conta o lado positivo trazido para a empresa, e o lado positivo trazido para os funcionários. A metodologia utilizada neste estudo foi uma pesquisa, quantitativa, qualitativa intencional, exploratória, descritiva dirigida para 3 grupos diferentes dentro da empresa, quem planejou e implantou o QVT, os gerentes de área e os colaboradores os quais compõem a amostra - universo da pesquisa. Descrevendo-se a percepção dos funcionários em relação a os programas de qualidade de vida na EMBRATUR. Quanto aos meios de pesquisa foi de campo, bibliográfica e estudo de caso. Foi utilizado tabulação em SPSS e gráficos da analise para a melhor visualização dos resultados.

Palavras-chave: 1. Gestão de pessoas 2. Qualidade de vida no trabalho 3. Colaboradores, 4. EMBRATUR. 


\begin{abstract}
The assessment of the results of People's Administration is nowadays one of the most challenging themes on this field and it's been receiving more and more funds. With respect to the issues related to the Administration of the Life Quality at Work Programs (LQW), too many expectations about the results are brought up when the subject is improving people's well being in their work environment, which influences directly or indirectly at the productivity and the financial result of the organization. This research studies the perception of the employees, this Program benefits at EMBRATUR. It was taken into consideration both the positive aspects brought to the enterprise and the positive aspects brought to the employees. The methodology used on this research was quantitative - fieldwork with TABULAÇÃO in SPSS and the analysis graphics for better view of the results - , intentional qualitative, exploratory enterprise - the one who planned and established the LQW, the field managers and the employees - that comprise the selection, research universe. Finally, is describe the perceptions of all the employees towards the LQW at EMBRATUR.
\end{abstract}

Key-words: 1. People's administration management, 2. Quality of life at work program, 3. Employee, 4. EMBRATUR 


\section{LISTA DE ORGANOGRAMAS}

$\begin{array}{ll}\text { Organograma } 1 \text { - Fatores de estresse } & 21\end{array}$

Organograma 2 - Estrutura organizacional da EMBRATUR 31 


\section{LISTA DE QUADROS}

Quadro 1 - Pessoas como recursos humanos ou parceiros

Quadro 2 - Categorias para avaliação do QVT 


\section{SUMÁRIO}

1. INTRODUÇÃO

2. REFERENCIAL TEÓRICO 5

2.1 GESTÃO DE PESSOAS

2.2 RECURSOS HUMANOS NAS ORGANIZAÇÕES- RELAÇÕES HUMANAS 8

2.3 RESPONSABILIDADE SOCIAL 9

2.4 MOTIVAÇÃO NAS ORGANIZAÇÕES 10

2.4.1 Impactos da motivação na organização 11

2.5 ESTRESSE E CUSTO HUMANO NO TRABALHO 12

2.5.1 Segurança 14

2.5.2 Complexo de Burnout $\quad 15$

2.6 QUALIDADE DE VIDA 18

2.7 QUALIDADE DE VIDA NO TRABALHO 19

2.7.1 Programas de qualidade de vida no trabalho 25

3. METODOLOGIA 26

3.1 UNIVERSO E AMOSTRA $\quad 27$

3.2 COLETA DE DADOS 28

4. A ORGANIZAÇÃO PESQUISADA: A EMBRATUR 29

4.1 A HISTÓRIA DA EMBRATUR $\quad 29$

4.2 ORGANOGRAMA DA EMBRATUR 31

4.3 O QVT DA EMBRATUR 33

5. ANÁLISE DOS DADOS 33

5.1 ANÁLISE QUALITATIVA 33

5.2 ANÁLISE QUANTITATIVA 36

5.2.1 Tabulações e Gráficos 36

5.2.2 Cruzamentos 48

5.3 SUGESTÕES DOS COLABORADORES 59

6. CONSIDERAÇÕES FINAIS $\quad 60$

REFERÊNCIAS BIBLIOGRÁFICAS $\quad 65$

APÊNDICE $1 \quad 66$

APÊNDICE 2

APÊNDICE $3 \quad 70$

APÊNDICE $4 \quad 76$

$\begin{array}{ll}\text { ANEXO } 1 & 77\end{array}$

ANEXO 2

ANEXO $3 \quad 86$

$\begin{array}{ll}\text { ANEXO } 4 & 87\end{array}$

$\begin{array}{ll}\text { ANEXO } 5 & 88\end{array}$ 


\section{INTRODUÇÃO}

Para combater o desgaste e o cansaço gerados pelo estresse no ambiente profissional, algumas organizações utilizam programas de qualidade de vida no seu cotidiano, visando facilitar e satisfazer às necessidades do trabalhador. O desenvolvimento de novas tecnologias tem provocado mudanças profundas em relação à produção, à intensidade e ao ritmo do trabalho, produzindo impactos consideráveis sobre os fatores produtivos, os indivíduos, as organizações, a cultura e o ambiente, refletindo-se, enfim, na qualidade de vida dos funcionários. Esse choque é ainda mais visível quando essas novidades tecnológicas transformam completamente a estrutura organizacional da empresa.

Diariamente, o funcionário lida com vários fatores que influenciam a sua performance: ritmo acelerado, aumento do absenteísmo, alta rotatividade das empresas, falta de infra-estrutura, más condições de trabalho, entre outros. Isso resulta, para ele, em estresse, sobrecarga de tarefas, acidentes laborais, depressão, doenças, uso de drogas, alcoolismo e tabagismo. Devido à estas questões, as organizações enfrentam muitos problemas, como aposentadoria por invalidez, doenças ocupacionais - LER (Lesões por Esforços Repetitivos) e DORT (Distúrbios Osteomusculares Relacionados ao Trabalho), disfunções psicossomáticas obesidade, hipertensão, depressão e síndrome do pânico -, e muitas outras ligadas ao ambiente corporativo.

A preocupação com a qualidade de vida é um assunto em ascensão no âmbito organizacional. Os empreendedores compreenderam que o ativo mais importante de uma instituição é o seu capital intelectual, ou seja, o homem, representado pelo talento, criatividade, conhecimentos e habilidades das pessoas que constituem seu corpo funcional. As organizações podem proporcionar qualidade de vida por intermédio de um ambiente favorável para 0 atendimento do desenvolvimento integral e das necessidades do ser humano. Sob uma perspectiva atual, vale considerar que esse tipo de qualidade consiste em priorizar-se a satisfação de necessidades e desejos, baseando-se na idéia de humanização do trabalho e de responsabilidade social das empresas. 
Diante deste cenário, empresas públicas e privadas perceberam a importância da melhoria das condições laborais, e implementaram programas que se propõem a otimizar a vivência, a convivência, a auto-estima e o moral dos seus funcionários. Dentre esses está o Programa de Qualidade de Vida no Trabalho (QVT), que é um conjunto de métodos para a satisfação do trabalhador no nível organizacional, onde se almeja o contentamento deste em relação à empresa, garantindo maior produtividade em seu cotidiano, e gerando benesses para a empresa, estabelecendo, assim, um relacionamento de reciprocidade entre as duas partes. Porém, notou-se que alguns funcionários não valorizavam ou não percebiam as melhorias aplicadas nas empresas que aplicaram a QVT, tornando-se necessária uma coleta de informações sobre como eles percebem esses programas, objetivando otimizar a sua implementação.

De acordo com esse contexto, esta pesquisa justifica-se pela necessidade de apresentar, em específico, a percepção dos empregados do Instituto Brasileiro de Turismo (EMBRATUR) em relação ao plano QVT em uso na instituição, mostrando que podem haver divergências nas visões dos benefícios deste programa dentro de uma empresa. A Qualidade de Vida no Trabalho visa equalizar os interesses dos indivíduos e das corporações, e tem como idéia básica o fato de as pessoas serem mais produtivas quanto mais estiverem satisfeitas e envolvidas com a sua atividade profissional. Ao melhorar a satisfação, melhora-se a produtividade da empresa, sendo que o comprometimento com o trabalho ocorre de forma mais natural, em um ambiente onde os funcionários sentem-se realizados.

A EMBRATUR é uma empresa que tem como proposta a promoção do Brasil como roteiro turístico no Exterior, é importante que os seus colaboradores sintam-se satisfeitos com a organização, pois seu estado de espírito implicará diretamente no seu desempenho, refletindo sobre a qualidade do seu trabalho, e mais a diante levando impactos positivos ou negativos para o sistema turístico. Os colaboradores quando motivados e satisfeitos com a organização exercerão seus cargos com mais empenho e aptidão, apresentando um produto/serviço com maior qualidade o que refletirá no aumento das vendas. 
Diante problemática exposta, o objetivo geral desta pesquisa é realizar um estudo de caso analisando o Programa de Qualidade de Vida no Trabalho da EMBRATUR segundo a visão dos seus colaboradores. Consequentemente, os objetivos específicos são:

- Fazer a analise de 3 visões dentro da organização estudada: a visão dos criadores do programa, a visão dos gerentes e supervisores; e a visão dos colaboradores em geral.

- Identificar os pontos de melhorias no Programa

- Apontar sugestões para o Programa.

A metodologia utilizada neste estudo foi baseada em uma pesquisa quantitativa dirigida para os colaboradores da Embratur, foram usados questionários estruturados com 12 questões fechadas e uma questão aberta. Após a coleta do material, os dados foram tabulados no software SPSS, e analisados segundo estatística descritiva e correlacional, para melhor visualização dos resultados. Com relação ao tamanho da amostra a Embratur possui um quadro de empregados composto por 201 colaboradores, a pesquisa quantitativa foi encaminhada aos setores, de forma a abranger todo o universo, houve um retorno de 80 questionários - representando uma amostragem de $40,9 \%$ do total dos empregados.

Também foi feita uma pesquisa qualitativa intencional, exploratória, descritiva dirigida para 3 grupos diferentes dentro da empresa, quem planejou e implantou o QVT, os gerentes de área e os colaboradores. Foram utilizados questionários semi-estruturados aplicados por meio de entrevistas, posteriormente tentou-se descrever a percepção dos funcionários em relação a os programas de qualidade de vida na EMBRATUR. Quanto aos meios de pesquisa foi de campo, bibliográfica e estudo de caso.

A estrutura do trabalho é composta por cinco capítulos, sendo este o primeiro, onde se pode ver uma rápida contextualização da pesquisa. No segundo capítulo é apresentado o referencial teórico, onde se especifica a atividade turística como um todo. Segue-se uma abordagem sobre o tema da gestão de pessoas, e um breve texto sobre relações humanas nas organizações e responsabilidade social. 
Nesta parte, ainda são abordados os temas Estresse e Custo Humano no Trabalho, O Complexo de Burnout, seguidos de Qualidade de Vida, Qualidade de Vida no Trabalho e Práticas da Qualidade de vida no Trabalho. Finalizando o referencial teórico, o último tópico versa sobre algumas características do objeto de estudo: a EMBRATUR. No terceiro capítulo é explicada a metodologia utilizada para a elaboração e pesquisa do presente estudo, e, no quarto, faz-se uma contextualização na análise dos dados coletados na EMBRATUR, culminando-se na última parte desta reflexão, onde são mostradas as conclusões desta pesquisa. 


\section{REFERENCIAL TEÓRICO}

\subsection{GESTÃO DE PESSOAS}

Segundo Dutra (2002), a gestão de pessoas é um conjunto de políticas e práticas que permitem a conciliação de expectativas entre a organização e as pessoas, para que ambas possam realizá-las ao longo do tempo. Já Chiavenato (2005) afirma que essa é uma área muito sensível à mentalidade que predomina nas empresas. Ela é contingencial e situacional, pois depende de vários aspectos, como a cultura que existe em cada uma delas, a estrutura organizacional adotada, as características do contexto ambiental, dos seus negócios, da tecnologia utilizada, dos processos internos, e de uma infinidade de outras variáveis importantes.

As empresas podem tratar as pessoas como seus recursos ou parceiros. Como recursos, elas precisam ser administradas, o que envolve planejamento, organização, direção e controle de suas atividades, já que são considerados sujeitos passivos da ação organizacional - daí o departamento de Recursos Humanos. Assim, é importante que exista uma administração eficaz desse componente para se abstrair o máximo de rendimento. As pessoas são fornecedoras de conhecimento, habilidades, competências e, principalmente, inteligência, e, quando são tratadas como parceiras, elas constituem parte integrante do capital intelectual das companhias, permitindo, com as suas qualidades, a tomada de decisões racionais, imprimindo significado e rumo aos objetivos globais. 
Quadro 1 - Pessoas como recursos humanos ou parceiros

\begin{tabular}{|l|l|}
\hline PESSOAS COMO RECURSOS & PESSOAS COMO PARCEIROS \\
\hline Empregados isolados nos cargos & Colaboradores agrupados em equipes \\
\hline Horário rigidamente estabelecido & Metas negociadas e compartilhadas \\
\hline Preocupação com normas e regras & Preocupação com os resultados \\
\hline Subordinação ao chefe & Atendimento e satisfação ao cliente \\
\hline Fidelidade à organização & Vinculação à missão e à visão \\
\hline Dependência da chefia & Interdependência com colegas de equipes \\
\hline Alienação a organização & Participação e comprometimento \\
\hline Ênfase na especialização & Ênfase na ética e na responsabilidade \\
\hline Executor de tarefas & Fornecedor de atividades \\
\hline Ênfase nas destrezas manuais & Ênfase no conhecimento \\
\hline Mão-de-obra & Inteligência e talento \\
\hline
\end{tabular}

Fonte: Chiavenato ( 2002)

A gestão de pessoas baseia-se em três aspectos fundamentais:

- As pessoas como seres humanos:

As pessoas são consideradas não como meros recursos, mas como seres humanos, dotados de personalidade, e profundamente diferentes entre si, cada qual com uma trajetória particular e diferenciada, possuidoras de conhecimentos, habilidades e competências indispensáveis à adequada gestão dos recursos organizacionais;

- As pessoas como ativadores inteligentes de recursos organizacionais:

Elas são consideradas elementos impulsionadores da instituição, capazes de dotá-la de inteligência, talento e aprendizagem, fatores estes indispensáveis à sua constante renovação e competitividade em um mundo cheio de desafios. As 
pessoas, dessa forma, são tidas como fonte de um impulso próprio que dinamiza a organização, e não como agentes passivos, inertes e estáticos;

- As pessoas como parceiras da organização:

Como parceiras, as pessoas investem na empresa seu esforço, dedicação, responsabilidade, comprometimento, riscos, etc., na expectativa de colherem resultados financeiros e/ou profissionais. Qualquer investimento somente se justifica quando traz um retorno razoável, e, na medida em que este se mostra bom e sustentável, a tendência certamente será de mantê-lo ou aumentá-lo - daí o caráter recíproco da interação entre a pessoa e a firma, e também o caráter das atividades e da autonomia dos empregados. Destarte, os funcionários são tratados como parceiros ativos da organização, e não como meros sujeitos passivos dela.

Os funcionários consistem no principal ativo das organizações, e surge a necessidade de torná-las mais atentas e conscientes quanto a eles. Aquelas mais bem sucedidas estão percebendo que apenas poderão crescer, prosperar, e se manter, se forem capazes de otimizar o retorno sobre os investimentos de todos os parceiros, incluindo os seus funcionários. Quando nos deparamos com uma companhia voltada para as pessoas, a sua filosofia global e sua cultura organizacional passam a refletir essa crença.

Então, a Gestão Pessoal passa a ser a função que permite a cooperação entre as pessoas - empregados, colaboradores, funcionários, recursos humanos, talentos, ou qualquer outra denominação utilizada para alcançar os objetivos organizacionais e individuais -, e o Departamento de Pessoal-Relações Industriais, Recursos Humanos, Desenvolvimento de Talentos, Capital Humano ou Capital Intelectual, que também são os utilizados para descrever a unidade, setor ou equipe relacionada com a gestão de pessoas. Estes componentes podem aumentar ou diminuir as forças e fraquezas de uma empresa, dependendo da maneira como são tratadas, podendo ser tanto a fonte de sucesso quanto de problemas para as corporações.

Podemos dizer que o procedimento de Gestão de Pessoas consiste de várias atividades integradas. É o conjunto de processos dinâmicos e interativos, e existem 6 pontos básicos para a sua efetivação: 
1) Processo de agregar pessoas: Pode ser chamado de processo de provisão, suprimento, ou, até mesmo, de recrutamento ou seleção de pessoas. São utilizados para incluir novos funcionários na empresas;

2) Processo de aplicar pessoas: São eles: desenho organizacional e de cargos, análise e descrição de cargos, orientação das pessoas e avaliação do desempenho. Utilizado para desenhar as atividades que as pessoas irão realizar na empresa, e para orientar e acompanhar sua performance;

3) Processo de recompensar pessoas: Utilizado para incentivar pessoas e satisfazer suas necessidades individuais mais elevadas, são eles: remuneração, recompensas, benefícios e serviços sociais;

4) Processo de desenvolver pessoas: Serve para capacitar e incrementar o desenvolvimento profissional e pessoal das pessoas. Inclui seu treinamento e desenvolvimento, a gestão do conhecimento e de competências, programa de mudanças e desenvolvimento de carreiras, e programas de comunicação e consonância;

5) Processo de manter pessoas: Cria condições ambientais e psicológicas satisfatórias para as atividades das pessoas. São elas: administração da cultura organizacional, clima, disciplina, higiene, segurança, qualidade de vida e manutenção de relações sindicais.

6) Processo de monitorar as pessoas: É usado para acompanhar e controlar as atividades das pessoas, e verificar resultados. Inclui banco de dados e sistema de informações gerenciais.

\subsection{RECURSOS HUMANOS NAS ORGANIZAÇÕES - RELAÇÕES HUMANAS}

As corporações têm enfrentado nos últimos tempos várias crises que se refletem tanto numa nova definição de seu papel social, quanto na profunda reflexão da importância de seus recursos humanos para a construção dos objetivos organizacionais. Chiavenato (1999) afirma que esta preocupação com os indivíduos tem-se revelado nas políticas adotadas pelas firmas, que cada vez mais tentam 
contemplar a globalidade do desenvolvimento humano. Esta preocupação com os indivíduos nas companhias tem-se observado nas diretrizes implementadas por elas mesmas, visando o desenvolvimento profissional e existencial das pessoas em relação às suas atividades produtivas. Ainda segundo o autor, as exigências, cada vez mais crescentes do meio ambiente, e de melhores condições de trabalho, têm obrigado os dirigentes das organizações a buscarem alternativas para definição de estratégias institucionais que tenham como meta o crescimento global dos indivíduos em seus empregos.

Chiavenato (1999, p. 171) nos diz também que as políticas de Recursos Humanos "constituem orientação administrativa para impedir que empregados desempenhem funções indesejadas ou ponham em risco o sucesso de funções específicas". Elas definem o modo de atrair, filtrar, manter e avaliar as pessoas que atuam nas empresas, servindo de guias ou referências aos componentes de seleção, treinamento, desenvolvimento e avaliação, dentre outras práticas que visem o aprimoramento das pessoas. Estes componentes, que variam de acordo com os interesses das instituições, têm como função direcionar a ação dos indivíduos para as metas fixadas por elas.

Ao estudarem o vínculo do funcionário com o trabalho, SIQUEIRA e GOMILDE JÚNIOR (2004) concluem que "se forem avaliados os níveis de satisfação, envolvimento e comprometimento dos empregados, será possível encontrar entre eles pessoas que estão satisfeitas e envolvidas com o trabalho e comprometidas com a organização onde trabalham".

\subsection{RESPONSABILIDADE SOCIAL}

Responsabilidade social empresarial é a forma de gestão que se define pela relação ética e transparente da empresa com todos os públicos com os quais ela mantém contato, e pelo estabelecimento de metas empresariais compatíveis com o desenvolvimento sustentável da sociedade, preservando-se, assim, os recursos ambientais e culturais para as gerações futuras, respeitando-se a diversidade e promovendo a redução das desigualdades sociais. A ética é a sua base, expressada nos princípios e valores adotados pela organização. 
A responsabilidade social se traduz na forma como uma instituição conduz suas atividades, de maneira a se tornar co-responsável pelo desenvolvimento da sociedade. Quando realmente aplicada, permeia a pesquisa científica, a gestão responsável, e também a extensão, sendo muito mais que a pura filantropia.

\subsection{MOTIVAÇÃO NA ORGANIZAÇÃO}

A motivação é um dos mais importantes processos que indica a conduta humana, especialmente no ambiente de trabalho. (ZANELLI,BORGES-ANDRADE, E BASTOS, 2004, p.145). As empresas anseiam por ter empregados motivados com o seu trabalho e com sua equipe e acima de tudo com a organização a qual perecem. Segundo os autores acima, a premissa é a de que altos níveis de motivação são capazes de melhorar o desempenho e garantir ganhos de produtividade.

"A motivação pode ser definida como uma ação dirigida a objetivos, sendo auto-regulada, biológica ou cognitivamente, persistente no tempo e ativada por um conjunto de necessidades, emoções, valores, metas e expectativas" (Salanova, Hontangas e Peiró, 1996, p.16)

Os autores explicam que a motivação esta associada a vários outros conceitos e destaca a satisfação, o envolvimento e o comprometimento. No caso da organização a satisfação se refere ao nível de contentamento com o sistema de recompensas e remuneração, contentamento com as relações entre chefes e colegas, o entrosamento com os demais funcionários, e contentamento com o trabalho realizado. O Envolvimento na organização diz respeito ao nível de identificação e de afinidade com o trabalho realizado. E o comprometimento organizacional se refere aos afetivos dirigidos a empresa, ao trabalho exercido ou a carreira.

Maslow (1943) afirma por meio da sua teoria da motivação, que as necessidades dos seres humanos obedecem a uma hierarquia, ou seja, uma escala de valores a serem transpostos. Isto significa que no momento em que o indivíduo realiza uma necessidade, surge outra em seu lugar, exigindo sempre que as pessoas busquem meios para satisfazê-la. Poucas pessoas procuram reconhecimento pessoal e status quando suas necessidades básicas estiverem 
insatisfeitas. De acordo com o autor, as necessidades fisiológicas constituem a sobrevivência do indivíduo e a preservação da espécie: alimentação, sono, repouso, abrigo. As necessidades de segurança constituem a busca de proteção contra a ameaça ou privação, a fuga e o perigo. As necessidades sociais incluem a necessidade de associação, de participação, de aceitação por parte dos companheiros, de troca de amizade, de afeto e amor. A necessidade de estima envolvem a auto apreciação, a autoconfiança, a necessidade de aprovação social e de respeito, de status, prestígio e consideração, além de desejo de força e de adequação, de confiança perante o mundo, independência e autonomia. As necessidades de auto realização são as mais elevadas, de cada pessoa realizar o seu próprio potencial e de auto desenvolver-se continuamente.

\subsubsection{Impactos da motivação organizacional}

Como visto anteriormente, a motivação é uma das grandes forças impulsionadoras do comportamento humano, ela é quem irá determinar os níveis de desempenho pessoal e profissional obtidos. Na empresa, está diretamente relacionada com sentimento satisfação, envolvimento e comprometimento.

Para Bekin (1995, P. 21)

"O público interno é um público primordial para o sucesso, ou seja, funcionários satisfeitos são sinônimos de lucros para os investidores. O sucesso de qualquer negócio depende mais do interesse interno dos funcionários do que da infra-estrutura existente na empresa. Para que isso aconteça estes devem estar satisfeitos com o que fazem, ter melhor remuneração compatível com a função e receber treinamentos continuados."

Sendo assim, a motivação é a maneira de trazer a interação e a satisfação entre o publico interno e o publico externo e consequentemente o lucro para a empresa, ou seja, é o marketing voltado para dentro da organização. A baixa motivação dos funcionários, sobretudo daqueles em contato direto com o cliente, pode constitui uma ameaça ao desempenho da empresa, e a comunicação deste com o consumidor. 
Uma das principais ferramentas para a motivação organizacional é o Endomarketing.

Segundo Brum (1998), "é um esforço feito por uma empresa para melhorar o nível de informação e, com isso estabelecer uma maior aproximação com o seu funcionário".

É fundamental que o Endomarketing proporcione aos funcionários educação e atenção, tornando-o preparado e bem informando para que possa tornar-se um vendedor digno de dignidade, responsabilidade e liberdade de iniciativa, capaz de atender ou superar os desejos do cliente. Ainda BRUM (1998) "a qualidade é alcançada através de resultados de pessoas felizes fazendo seu trabalho"

Dentro deste contexto, entende-se que a motivação e satisfação do colaborador propicia melhor qualidade dos produtos/serviços, melhora a comunicação, realiza melhor comunicação interna e externa, sendo fundamental para atender os desejos e alçando assim a satisfação dos clientes externos.

Os clientes, normalmente, escolhem a oferta que maximiza o valor do produto entregue. Consumidores satisfeitos permanecem leais por mais tempo, podendo aumentar o volume e a freqüência de aquisições, tornando-se menos sensíveis a preço e divulgam favoravelmente a empresa.

\subsection{ESTRESSE E CUSTO HUMANO NO TRABALHO}

O estresse é reconhecido como um dos riscos mais sérios ao bem estar psicossocial do indivíduo (ROSSI, PERREWÉ e SAUTER apud BATERMAN e STRASSER, 1983, p.09), e o trabalho associado a ele pode colocar em risco a saúde dos membros das empresas. Estudos indicam que a estrutura corporativa, o ambiente profissional, e diversos outros fatores presentes entre o empregado e a sua ocupação, contribuem para as respostas individuais de estresse e tensão, resultando em problemas de desempenho ruim, baixo moral, alta rotatividade, absenteísmo e violência dentro da companhia.

O estresse já recebeu muitas definições. Dentre elas, pode-se destacar a de Chiavenato (2005), que afirma ser este um conjunto de reações físicas, químicas e mentais de um indivíduo, decorrente de algum estímulo ou agente estressante que 
possa existir no ambiente. É uma condição dinâmica, a qual uma pessoa é confrontada com uma oportunidade, restrição ou demanda relacionada com o que ela deseja. Entretanto, mesmo não havendo um consenso sobre sua definição embora tenha-se escolhido a do autor acima para esta pesquisa - pelo menos compartilha-se a posição sobre a existência de dois tipos - um funcional e um disfuncional (burnout) -, e que, em demasia ou em baixas doses, ele pode ser prejudicial. Autoritarismo do chefe, desconfiança, pressão das exigências e cobranças, cumprimento de horários, monotonia de certas tarefas, baixo astral do colega, falta de perspectiva de progresso profissional e insatisfação pessoal não somente derrubam o bom humor, como também provocam o estresse no serviço, causando efeitos negativos como ansiedade, depressão, e baixa auto-estima

Ainda para Chiavenato (2005, p.433), o estresse não é, necessariamente, disfuncional. Algumas pessoas trabalham bem sob pequena pressão, e são mais produtivas em uma abordagem de cobranças de metas, enquanto outras buscam, por si só e incessantemente, mais produtividade e qualidade. Um nível modesto de estresse conduz a uma maior criatividade, quando uma situação competitiva conduz a novas idéias e soluções. Na maioria das vezes, muitos empregados não se preocupam com uma pequena pressão, desde que ela possa conduzir a conseqüências positivas, pois observa-se que, partindo-se de um ponto inicial de nenhuma tensão, o desempenho do indivíduo tende a aumentar na medida em que o estresse aumenta, até alcançar um patamar o qual pode-se averiguar um nível ótimo de rendimento. Deste ponto em diante, o desempenho tende a cair, em um contexto o qual o indivíduo se sente sobrecarregado, não conseguindo corresponder de maneira eficaz às exigências profissionais.

Pode-se dizer, então, que o estresse é a soma das perturbações orgânicas e psíquicas provocadas por diversos agentes agressores, como traumas, emoções fortes, fadiga, exposição a situações problemáticas e de conflito. Certos fatores relacionados ao serviço, como sobrecarga de atividade, pressão de tempo e urgência, relações conturbadas com chefes ou clientes, provocam reações como nervosismo, inquietude, tensão, etc., desdobrando-se em outros, como a dependência do álcool e o abuso de drogas. Existem duas fontes principais de estresse no trabalho: a ambiental e a pessoal. A primeira diz respeito a uma variedade de fatores externos que podem conduzir às tensões, como a programação 
das tarefas, a segurança, o fluxo, o número e a natureza de clientes internos e/ou externos a serem atendidos. Além disso, pesquisas revelam que o ruído ambiental decorrente de máquinas funcionando, conversas, e telefones tocando, contribuem em $54 \%$ para o aumento desse problemático componente emocional.

Em relação à segunda fonte, cada indivíduo apresenta uma reação específica para cada situação. Personalidades do tipo A, aquelas que são viciadas em trabalho (workaholics), e que são impulsionadas para alcançar metas, geralmente estão mais sujeitas ao estresse do que outras. Sua tolerância para ambigüidade, paciência, auto-estima, saúde e exercícios físicos, hábitos profissionais e sono afetam a maneira com a qual elas reagem às pressões. Além do serviço, problemas pessoais, familiares, conjugais, financeiros e legais, contribuem para aumentar o estresse do funcionário, provocando sérias conseqüências tanto para o empregado quanto para a organização, gerando, para aquele, ansiedade, depressão, angústia e várias conseqüências físicas, como: distúrbios gástricos e cardiovasculares, dores de cabeça, nervosismo e acidentes.

\subsubsection{Segurança}

Segundo Chiavenato (2005, p.438), "segurança no trabalho é o conjunto de medidas técnicas, educacionais, médicas e psicológicas utilizadas para prevenir acidentes, quer eliminando condições inseguras no ambiente, quer instruindo ou convencendo as pessoas da implantação de praticas preventivas".

Ela envolve três áreas principais: prevenção de acidentes, incêndios e roubos, sendo a principal delas a primeira, relativa à prevenção de acidentes e administração de riscos ocupacionais. Os acidentes no ambiente de trabalho constituem um fator negativo, e suas causas e custos devem ser analisados para remover eventuais condições ou atos que tragam risco.

O seguro, nesse caso, cobre apenas as despesas com tratamentos e indenização aos acidentados, mas não repõe a capacidade laboral, nem a integridade física do acidentado, constituindo-se o fator da segurança, dessa maneira, como deveras importante para a manutenção dos talentos e sua respectiva produtividade na instituição. 
Organograma 1 - Fatores de estresse

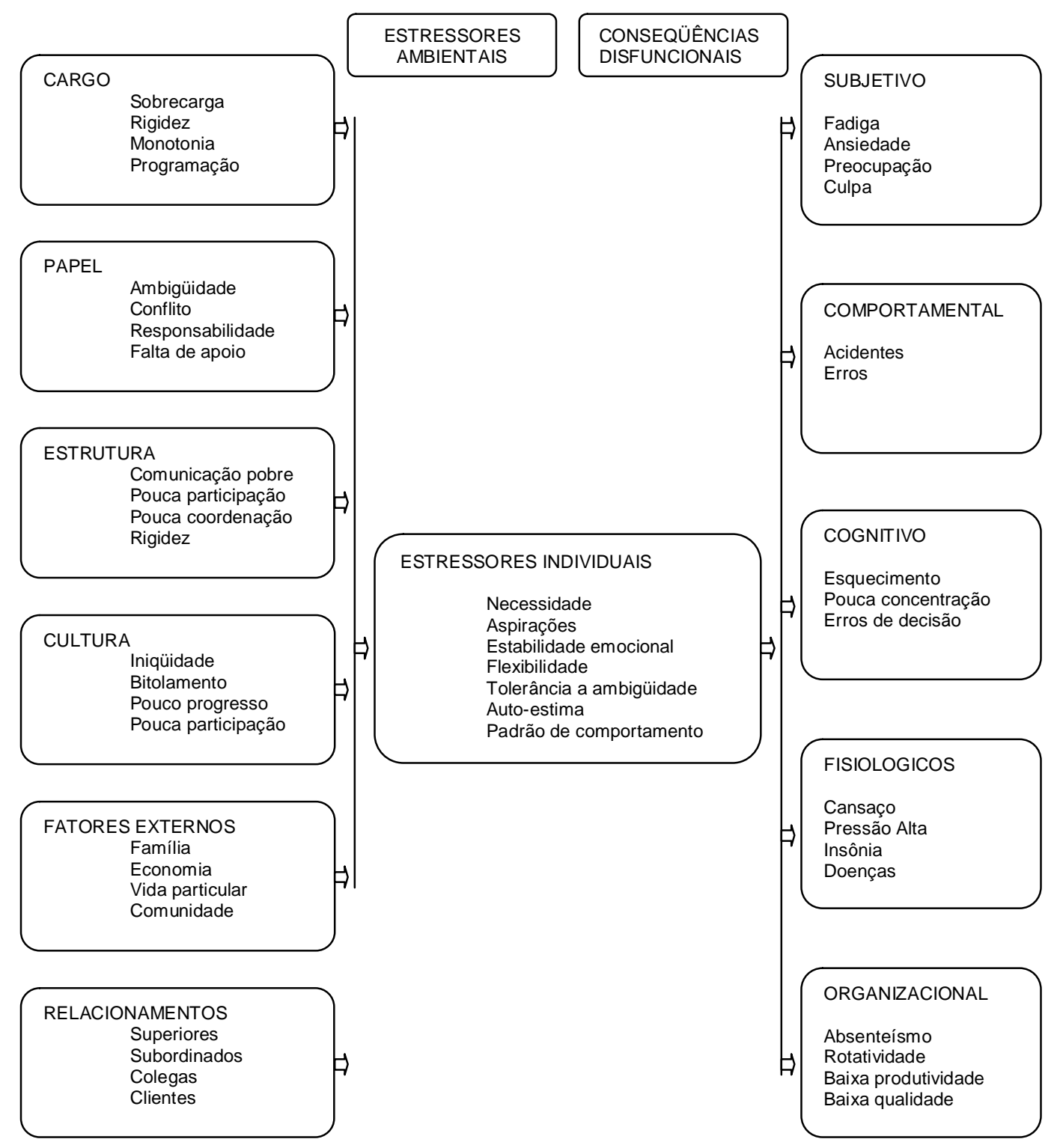

\subsubsection{Complexo de Burnout}

Burnout é uma síndrome que corresponde ao estresse ocupacional crônico, e pode ser caracterizada pela desmotivação, desinteresse, mal estar interno ou insatisfação ocupacional que parece afetar, em maior ou menor grau, alguma categoria ou grupo profissional. Segundo Maslach (apud ROSSI, PERREWÉ e SAUTER, 2005, p.41), as três principais dimensões desta reação são a exaustão 
avassaladora, a sensação de ceticismo e desligamento do trabalho, e uma sensação de ineficácia e falta de realização.

A palavra Burnout vem da junção entre burn (queima) e out (exterior), sugerindo, assim, que a pessoa possuidora desse tipo de estresse consome-se física e emocionalmente, e desenvolve um comportamento agressivo e irritadiço. Seus principais indicadores são, inicialmente, uma exaustão emocional onde o indivíduo sente que não pode mais dar nada de si, seguido de sentimentos e atitudes muito negativas, como, por exemplo, cinismo na relação com os colegas da empresa, e aparente insensibilidade afetiva. Finalmente, o paciente manifesta sentimentos de falta de realização profissional, afetando sobremaneira a eficiência e a habilidade para a realização de tarefas, e a adequação à organização.

Muitos autores explicam a diferença entre Burnout e estresse como sendo o primeiro envolvendo atitudes e condutas negativas com relação aos usuários, clientes, organização e trabalho, enquanto o outro aparece mais como um tipo de esgotamento pessoal, com interferência na vida do sujeito e, não necessariamente, na sua relação com o trabalho. O Burnout seria a conseqüência mais depressiva do estresse desencadeado pela atividade profissional.

A síndrome é causada por variáveis situacionais, e os seus fatores de risco devem-se mais à natureza do serviço do que às características do indivíduo. As situações que causam o Burnout são:

- Sobrecarga de tarefas: É o desequilíbrio entre as exigências do trabalho e a capacidade de indivíduo em atendê-las, como, por exemplo, empregados com várias tarefas para executar que sentem não possuírem tempo nem recursos suficientes para realizá-las bem, podendo levá-los a sacrificarem seu tempo fora do expediente para concluí-las;

- Falta do controle: Este fator pode elevar o nível de estresse no individuo, quando empregados não podem, por exemplo, usar da sua própria sabedoria e experiência para tomar decisões, ou possuem uma vida profissional caótica, sendo que suas tarefas não dependem da sua 
experiência e sabedoria, ou mesmo são solicitados para trabalhar fora do expediente sem serem informados com antecedência;

- Recompensas Insuficientes: Funcionários que não são recompensados ou não o são satisfatoriamente - por seu desempenho, tanto através das formas usuais, como salário, benefícios e vantagens, quanto pelo reconhecimento da tarefa efetuada. Funcionários podem sentirem-se não recompensados quando acham que não estão sendo reconhecidos pelo seu serviço, acarretando o desenvolvimento da sindrome;

- Ruptura da comunidade: É a quebra da harmonia nas relações entre pessoas na empresa devido a uma falta de confiança, de apoio, ou a um conflito não resolvido. Empregados lidam regularmente com indivíduos para quem prestam serviço, com colegas, chefes, fornecedores, ou outros de fora da organização, mas, quando essa comunidade apresenta atritos, pode haver um sentimento de hostilidade e concorrência, o que dificultará a resolução dos problemas.

- Falta de justiça: Reflete-se em injustiça e desigualdade no local de trabalho. Pessoas que sentem uma desigualdade no seu ambiente profissional podem tomar diversas medidas para tentar recuperá-la. Exemplo disso é o empregado que prejudica o colega por achar que ele não recebe o mesmo tratamento, pensando que isso vai favorecê-lo de alguma forma.

- Conflitos de valor: Valores conflitantes relacionados ao ambiente organizacional, como embates internos na empresa e atritos entre os valores pessoais e os da companhia, como é o caso de empregados que divergem das suas obrigações e fazem o serviço que bem entendem.

Dentre os outros fatores associados ao desenvolvimento da Síndrome de Burnout estão: a pouca autonomia no desempenho profissional, problemas de relacionamento com as chefias, de relacionamento com colegas e/ou clientes, conflito entre trabalho e família, sentimento de desqualificação, e falta de cooperação da equipe. Geralmente essa síndrome incorpora sentimentos de fracasso. 


\subsection{QUALIDADE DE VIDA}

Qualidade de vida é mais do que ter uma boa saúde física ou mental. O próprio conceito de saúde é reformulado nessa concepção, o qual passa a ser não a mera ausência de doença, mas sim, uma série de fatores que levam ao bem-estar humano.

Podemos dizer que ela compreende as condições gerais de vida, tanto individual como coletiva. Uma boa habitação, saúde, educação, cultura, lazer e alimentação referem-se aos aspectos de bem-estar social. As condições para uma existência agradável englobam uma série de variáveis a serem atendidas, excluindose, aqui, as restritas às histórias individuais, como doenças ou tendências hereditárias: satisfação adequada das necessidades biológicas e a conservação de seu equilíbrio, manutenção de um ambiente propício à segurança pessoal, a possibilidade de desenvolvimento cultural, e um contexto social que estimule a comunicação entre os seres humanos, como base para a estabilidade psicológica e criativa. Daí que desdobra-se o conceito de saúde, com já mencionado, não mais tida como a simples ausência de doenças, mas significando uma série de fatores que levam ao bem-estar humano. Assim, uma boa vida

É a resultante da saúde de uma pessoa (avaliada objetiva ou intersubjetivamente) e do sentimento (subjetivo) da satisfação. A saúde depende dos processos internos de uma pessoa e do grau de cobertura de suas necessidades, e a satisfação depende dos processos internos e do grau de cobertura dos desejos e aspirações. (GALLOPIN, 1981, p.18)

Para garantir uma boa qualidade de vida é necessário estar de bem consigo mesmo, com as pessoas queridas, buscando-se sempre o equilíbrio. Para alcançar esses resultados é preciso administrar a existência de forma saudável, e isso pressupõe certos cuidados com o corpo, com a alimentação, a prática de bons hábitos, atenção para a qualidade dos seus relacionamentos, equilíbrio entre o pessoal e o profissional, tempo para lazer, saúde espiritual, saber lidar com momentos de estresse, definir objetivos de vida, e sempre sentir que se tem controle sobre ela. Ser competente na gestão da própria saúde e do comportamento deveria ser uma prioridades de todos. 


\subsection{QUALIDADE DE VIDA NO TRABALHO}

A qualidade de vida no trabalho diz respeito ao bem estar geral e à saúde dos funcionários no desempenho de suas tarefas. Hoje em dia, este conceito se refere tanto ao lado físico quanto psicológico do local de serviço, e engloba dois aspectos: o empregado e a organização. Conclui-se que a empresa, ao aderir aos programas de melhoria da qualidade de vida, se compromete a fornecer bem-estar e satisfação geral aos seus colaboradores, mostrando a importância destes na organização, enquanto a sua satisfação torna-se um elemento potencializador para a produtividade e a qualidade no trabalho.

A QVT pode ser entendida como um programa que visa facilitar e satisfazer as necessidades do trabalhador ao desenvolver suas atividades na empresa, tendo como idéia básica o fato de que as pessoas são mais produtivas quanto mais estiverem satisfeitas e envolvidas com o próprio serviço.

A prática da QVT eleva o sentimento de satisfação do empregado para com a empresa, garantindo maior produtividade nas suas tarefas, e gerando satisfação para o empreendimento, estabelecendo um relacionamento de reciprocidade com o trabalhador, em níveis organizacionais. Funcionários que se sintam motivados, capacitados e bem remunerados provavelmente passarão a ter um melhor desempenho.

Para Chiavenato (2005,p. 448) a QVT envolve dois aspectos. Ela:

assimila duas posições antagônicas: de um lado, a reivindicação dos empregados quanto ao bem estar e a satisfação no trabalho; e, de outro, o interesse das organizações quanto aos seus efeitos potencializadores sobre a produtividade e a qualidade.

A QVT deve ser considerada como uma gestão dinâmica, porque as organizações e as pessoas mudam constantemente, e contingencial, porque sua implementação e adaptação dependem da realidade de cada empresa no contexto o qual está inserida. Além disso, pouco resolve atentar-se apenas para fatores físicos, pois aspectos sociológicos e psicológicos interferem igualmente na satisfação dos 
indivíduos em situação de trabalho, assim como os aspectos tecnológicos da coordenação das tarefas, que, em conjunto, afetam a cultura e interferem no clima organizacional, refletindo na produtividade e na satisfação dos empregados. Como meta principal do programa de QVT, pode-se considerar a conciliação dos interesses dos indivíduos e das companhias, ou seja, ao melhorar-se a satisfação do funcionário, melhora-se a produtividade da empresa. Como sintetiza Limongi-França (2004,p.24), "QVT é uma competência gerencial para o administrador e uma competência estratégica para a organização".

O conceito de Qualidade de Vida no Trabalho é bem mais amplo do que aquele que normalmente se procura delimitar. As ações do programa vão muito além do lazer - sob as mais diferentes formas -, ou preocupações com aspectos da saúde ocupacional - ergonomia e ambientes físicos da ocupação. A QVT corresponde à remuneração, em seus aspectos de eqüidade ou justiça interna ou externa, às condições de saúde e segurança laboral, e também às oportunidades para utilização, desenvolvimento de capacidade e crescimento profissional, assim como segurança, integração social no ambiente profissional, direitos e deveres formalmente estabelecidos e cumpridos pela organização, imparcialidade nas decisões, e influência do serviço em outras esferas de vida do funcionário. Ainda para Limongi-França (2004,p.24)

As definições de QVT vão desde cuidados médicos estabelecidos pela legislação de saúde e segurança até atividades voluntárias dos empregados e empregadores nas áreas de lazer, motivação, entre inúmeras outras.

Walton (1973) propõe oito categorias para se avaliar QVT, conforme apresentado no quadro abaixo, e explicado a seguir. 
Quadro 2 - Categorias para avaliação do QVT

\begin{tabular}{|l|l|}
\hline CATEGORIAS & PRINCIPAIS INDICADORES \\
\hline $\begin{array}{l}\text { Compensação Justa e } \\
\text { Adequada }\end{array}$ & $\begin{array}{l}\text { A equidade interna e externa, a justiça na compensação e partilha de } \\
\text { ganhos de produtividade e proporcionalidade entre salários. }\end{array}$ \\
\hline Condições de Trabalho & A jornada de trabalho e a qualidade e segurança do ambiente físico. \\
\hline $\begin{array}{l}\text { Uso e desenvolvimento } \\
\text { de capacidades }\end{array}$ & $\begin{array}{l}\text { A autonomia do funcionário, o auto-controle relativo às qualidades } \\
\text { múltiplas e as informações sobre o processo total do trabalho. }\end{array}$ \\
\hline $\begin{array}{l}\text { Oportunidade de } \\
\text { Crescimento e } \\
\text { Segurança }\end{array}$ & $\begin{array}{l}\text { A possibilidade de carreira e crescimento pessoal, as perspectivas de } \\
\text { avanço salarial e segurança de emprego. }\end{array}$ \\
\hline $\begin{array}{l}\text { Integração Social na } \\
\text { Organização }\end{array}$ & $\begin{array}{l}\text { A ausência de preconceitos, a igualdade, o relacionamento e o senso } \\
\text { comunitário. }\end{array}$ \\
\hline $\begin{array}{l}\text { Constitucionalismo } \\
\text { Os direitos de proteção do trabalhador, a privacidade pessoal, a } \\
\text { liberdade de expressão, o tratamento imparcial e os direitos } \\
\text { trabalhistas. }\end{array}$ \\
\hline $\begin{array}{l}\text { Trabalho e Espaço } \\
\text { Total de Vida }\end{array}$ & $\begin{array}{l}\text { O papel balanceado no trabalho, a estabilidade de horário, as } \\
\text { mudanças geográficas, o tempo para lazer da família. }\end{array}$ \\
\hline $\begin{array}{l}\text { Relevância Social da } \\
\text { Vida no Trabalho }\end{array}$ & $\begin{array}{l}\text { A imagem da empresa na comunidade, a responsabilidade social da } \\
\text { empresa, a responsabilidade pelos produtos e as práticas da empresa. }\end{array}$ \\
\hline
\end{tabular}

Fonte: Chiavenato (2005, p. 451)

a) Compensação justa e adequada: Caracteriza pela remuneração recebida por um trabalho realizado, dividindo-se, esta, em dois critérios:

- Remuneração adequada: é o suficiente para o empregado viver dignamente dentro das necessidades pessoais e dos padrões culturais, sociais e econômicos da sociedade em que vive;

- Equidade interna: Equidade na remuneração entre outros membros de uma mesma organização;

- Equidade externa: Equidade na remuneração em relação a outros profissionais no mercado de trabalho. 
b) Condições de trabalho: Caracteriza pelas condições existentes no local de serviço, e que apresenta os seguintes parâmetros:

- Jornada de trabalho: Número de horas trabalhadas, previstas ou não pela legislação, e sua relação com as tarefas desempenhadas;

- Carga de trabalho: Quantidade de tarefas executadas dentro do expediente;

- Ambiente físico: Local de trabalho em relações às condições de bem estar (conforto) e organização para o desempenho profissional;

- Material e equipamento: Quantidade e qualidade de material disponível para execução do serviço;

- Ambiente saudável: Local de trabalho em relação às suas condições de segurança e de saúde em relação aos riscos de injúria ou doenças.

- Estresse: Quantidade percebida de estresse a que o profissional é submetido na sua laboriosa jornada.

c) Uso e desenvolvimento de capacidade: É a mensuração da qualidade de vida no trabalho em relação às oportunidades que o empregado tem de aplicar, no seu dia a dia, seus saberes e suas aptidões profissionais. Entre os critérios, destacam-se:

- Autonomia: Medida permitida ao indivíduo para o uso de uma liberdade substancial, de independência e discrição na programação e execução do trabalho;

- Significado da tarefa: Relevância da tarefa desempenhada na vida e no trabalho de outras pessoas, dentro ou fora das instituições;

- Identidade da tarefa: Medida de tarefa na sua integridade e na avaliação do resultado; 
- Variedade de habilidades: Possibilidade de utilização de uma grande quantidade de capacidades do individuo;

- Retro-informação: Informação ao indivíduo acerca da avaliação do seu serviço e de suas ações com um todo.

d) Oportunidade de crescimento e segurança: Caracteriza-se pelas oportunidades que a instituição estabelece para o crescimento pessoal de seus empregados e para segurança do emprego. Os critérios que expressam a importância do desenvolvimento e a perspectiva de sua aplicação são os seguintes:

- Possibilidade de carreira: Viabilidade de oportunizar avanços na instituição e na carreira, reconhecidos por colegas, membros da família, comunidade;

- Crescimento pessoal: Processo de educação continuada para o desenvolvimento das potencialidades do indivíduo e aplicação das mesmas no cotidiano;

- Segurança de seu emprego: Grau de segurança dos empregados quanto à manutenção de suas ocupações.

e) Integração social na organização: É o grau de integração social existente na instituição. Compreende:

- Igualdade de oportunidades: Grau de ausência de estratificações na organização de trabalho em termos de "status" ou estruturas hierárquicas íngremes, e de discriminação quanto à etnia, sexo, credo, origens, estilos de vida e aparência;

- Relacionamento: É o nível de relacionamento, marcado por auxílio recíproco, apoio sócio-emocional, abertura inter-pessoal e respeito às individualidades;

- Senso comunitário: Grau de senso de comunidade existente na instituição. 
f) Institucionalismo: Caracteriza-se pelos direitos dos empregados cumpridos na instituição, e diz respeito a:

- Direitos trabalhistas: Observância quanto ao cumprimento dos direitos do trabalhador, inclusive do acesso à apelação;

- Privacidade social: Grau de privacidade que o empregado possui dentro da instituição;

- Liberdade de expressão: Forma de como o empregado pode expressar seus pontos de vista aos superiores, sem medo de represálias;

- Normas e rotinas: Maneiras e regras específicas que influenciam o desenvolvimento da tarefa.

g) Trabalho e espaço total de vida: É o equilíbrio entre a vida social e a vida profissional do empregado. É expresso por um:

- Papel balanceado no trabalho: Equilíbrio entre o expediente na firma, as exigências da carreira, viagens e convívio familiar.

- Horário de entrada e saída do trabalho: Equilíbrio entre horários de entrada e saída da companhia e convívio familiar.

h) Relevância social da vida no trabalho: Percepção do empregado em relação à responsabilidade social da instituição na comunidade, à qualidade da prestação dos serviços, e ao atendimento de seus funcionários: Divide-se em:

- Imagem da instituição: Visão do empregado em relação à empresa que o contrata, à importância desta para comunidade, e também o sentimento de orgulho e satisfação por pertencer ao quadro profissional da instituição;

- Responsabilidade social da instituição : Percepção do empregado quanto à responsabilidade social da companhia para com a 
comunidade, refletida na preocupação não só de resolver os seus problemas, mas também de não causá-la danos;

- Responsabilidade social pelos serviços: Percepção do empregado quanto à responsabilidade da instituição com a qualidade dos serviços postos à disposição da comunidade;

- Responsabilidade social para com os empregados: Percepção do empregado quanto à sua valorização e participação na instituição à partir da política de recursos humanos.

A QVT pode ser vista como uma gestão dinâmica e contingencial de fatores físicos, tecnológicos e sócio-psicológicos que afetam a cultura e renovam o clima organizacional, refletindo-se no bem-estar do empregado e na produtividade das empresas.

\subsubsection{Programas de qualidade de vida no trabalho}

Os programas normalmente são adotados por empresas que procuram prevenir problemas de saúde em seus funcionários, e são utilizados para buscar integrar o bem-estar destes com a produtividade da corporação. Essas experiências incentivam a participação dos gestores e dos servidores, a criação de grupos de trabalho representativos das diferentes áreas da empresa, e visam, principalmente, mudanças na cultura organizacional. A implementação de ginástica laboral, a preocupação com a ergonomia e a melhoria do ambiente físico ocupado pelo empregado, o estímulo à realização de check-ups periódicos e o combate ao tabagismo e ao alcoolismo no meio profissional, o incentivo à prática de esportes e outras modalidades físicas e sociais, como aulas de dança de salão, coral, confraternizações e festas comemorativas, são exemplos de medidas de QVT que uma firma pode operacionalizar. 


\section{METODOLOGIA}

A metodologia utilizada neste estudo foi a pesquisa descritiva exploratória, mostrando-se as diferentes percepções dos funcionários em relação aos programas de qualidade de vida da EMBRATUR. Quanto aos meios, ela foi de campo, bibliográfica e estudo de caso, sendo que o estudo foi feito através de dois tipos de investigação: uma quantitativa, que englobou uma amostra de 80 colaboradores respondentes aleatórios, e outra qualitativa, respondida pelo Gerente de $\mathrm{RH}$, por dois Gerentes de Áreas e 10 funcionários julgados formadores de opinião. A pesquisa foi realizada na EMBRATUR, onde os indivíduos que compõem a amostra atuam.

A pesquisa qualitativa possui realidade que não pode ser quantificada, enquanto a quantitativa tem como suporte medidas e cálculos mensuráveis.

Por sua vez, a pesquisa qualitativa possui perguntas abertas e respostas pessoais e espontâneas, agregando dados importantes, pois estas últimas não são previstas. O mesmo autor acima caracteriza estudo de caso como sendo uma forma de abranger as características mais importantes do tema que se está pesquisando, e do seu processo de desenvolvimento. O caso se constrói no processo de investigação conforme se identificam os fatores que o compõem.

Ao realizar o estudo sobre o Instituto Brasileiro de Turismo, classifica-se a pesquisa, segundo o tratamento dos dados, como qualitativa, onde procura-se conhecer, em maior profundidade, a reação psicológica do entrevistado e seu envolvimento emocional, buscando qualificar os indivíduos por meio de abordagens que envolvam análise de atitude, comportamento e motivação. Segundo Dencker (2001, p.98), "... a maioria das pesquisas qualitativas se propõe a preencher lacunas do conhecimento, tendo caráter descritivo exploratório e poucas se originam no campo teórico".

De acordo os critérios apresentados por Spézia (2006), a metodologia de investigação deve ser classificada quanto ao objetivo, à técnica e à classificação do estudo. Assim, o método de abordagem, de acordo com os objetivos desta monografia, foi o inquérito descritivo exploratório, onde fez-se uma pesquisa 
bibliográfica abordando os temas necessários para a compreensão do estudo como gestão de pessoas, qualidade de vida no trabalho, estresse, entre outros -, aplicou-se um questionário com funcionários da firma estudada, e procedeu-se uma descrição da organização e das suas práticas de qualidade de vida no trabalho.

O método de abordagem foi o da realização da avaliação dos resultados, onde as respostas dos funcionários atribuíram valor à pesquisa, sendo também o momento da avaliação de diferentes pontos de vista, dentro da mesma empresa, em relação ao QVT.

O método de abordagem, segundo o procedimento técnico, foi uma pesquisa bibliográfica e um estudo de caso. A primeira foi dada pela busca em materiais já existentes - livros, artigos científicos, livros de referência, publicações periódicas e impressos diversos. O estudo de caso justifica-se pela reunião de uma série de dados coletados na organização pesquisada, e que descrevem, em parte ou totalmente, o processo social de uma unidade em suas relações internas e sociais.

\subsection{UNIVERSO E AMOSTRA}

A EMBRATUR localiza-se em Brasília, sendo o seu quadro de funcionários composto por 201 colaboradores, sendo 127 servidores, 32 terceirizados e 42 estagiários. A pesquisa quantitativa foi encaminhada aos setores, de forma a abranger todo o universo, tendo sido o período de coleta entre 27/06/2007 e 29/06/2007, com um retorno de 80 questionários - representando uma amostragem de $40,9 \%$ do total dos empregados. Porém 9 questionários foram desconsiderados por haver muitas respostas em branco, não possuindo assim, validez para analise. As listas de perguntas foram aplicadas individualmente, sem identificação pessoal, e com o maior número possível de entrevistados de cada área da empresa, na tentativa de tornar os dados reais e precisos. Após a coleta do material, tabularamse os dados com o auxilio do software SPSS, e analisou-se segundo estatística descritiva e correlacional, diagnosticando-se, assim, o programa de QVT da instituição segundo a percepção dos colaboradores. 
A pesquisa qualitativa foi aplicada por de meio de entrevistas semiestruturadas realizadas com 13 funcionários, representando as pessoas formadoras de opinião que têm mais tempo de casa ou grande influência na organização, e o responsável pela criação do programa QVT EMBRATUR. Essas corresponderam a um questionário para o gerente de $\mathrm{RH}$, dois para os gerentes de áreas, e dez para os funcionários, tendo sido realizadas entre 01/03/2007 e 20/03/2007.

\subsection{COLETA DE DADOS}

Os instrumentos de pesquisa quantitativa utilizados foram os questionários estruturados com 12 perguntas fechadas de múltipla escolha e uma pergunta aberta (vide Apêndice 4), deixando-os mais adequados à quantificação, e mais fáceis de codificar e tabular, permitindo correlacionar com outros dados do mesmo questionário.

$\mathrm{Na}$ pesquisa qualitativa foram utilizadas entrevistas feitas por meio de questionários semi-estruturados, elaborados com perguntas abertas, que versavam sobre temas que permitissem diagnosticar a percepção do programa QVT na instituição segundo a visão dos colaboradores, dos gerentes e do responsável pelo esquema de qualidade (vide Apêndices 1, 2 e 3). Os questionários foram aplicados individualmente, e não foi solicitada a identificação pessoal.

Cervo e Bervian (2000,p.46) afirmam que a entrevista "é uma conversa orientada para um objeto definido: recolher, por meio do interrogatório do informante, dados para a pesquisa (...) [, e] fornecem dados que não podem ser encontrados em registros e fontes documentais".

Vale ressaltar que ocorreram algumas limitações na coleta de dados, pois o período da mesma coincidiu com férias e licenças médicas de alguns colaboradores, e, também, porque alguns dos colaboradores se recusaram a participar. Contudo, o objetivo deste estudo foi atingido, pois puderam-se obter impressões sobre as percepções dos funcionários, dos gerentes e do responsável pelo programa. 


\section{A ORGANIZAÇÃO PESQUISADA: A EMBRATUR}

O Instituto Brasileiro de Turismo - EMBRATUR -, sediado em Brasília, DF, foi criada pelo decreto - Lei $\mathrm{N}^{\circ} 55$, de 18 de novembro de 1966 pelo então presidente da República General Humberto de Alencar Castelo Branco, como Empresa Brasileira de Turismo, vinculada ao Ministério da Indústria e Comércio, em substituição à Divisão de Turismo e ao CERTAMES, do Departamento Nacional do Comércio, sendo a primeira empresa pública do Brasil.

A EMBRATUR é regida pelo Conselho Nacional de Turismo (CNTUR, criado pelo decreto $N^{\circ} 55$, de 18 de novembro de 1966, juntamente com a criação da Empresa Brasileira de Turismo), e suas competências dizem respeito ao incremento da indústria de turismo, o financiamento de programas e projetos, o estudo do mercado turístico, a fiscalização e a regulamentação das empresas do setor, e a organização de todas as atividades ligadas ao turismo.

\subsection{A história da EMBRATUR}

Em 28 de março de 1991, pela lei $N^{\circ} 8.181$, no governo de Fernando Affonso Collor de Mello, a EMBRATUR passou a ser considerada Autarquia Especial, e ganhou a condição de Instituto em 28 de março de 1991. Na ocasião, adotou-se a denominação atual - Instituto Brasileiro de Turismo - e foi vinculada à Secretaria de Desenvolvimento Regional da Presidência da República, responsável pela coordenação e execução da Política Nacional de Turismo, competência do extinto CNTUR. Acumula funções de regulamentar o uso e a ocupação de áreas, estimulando o aproveitamento e preservação dos recursos turísticos naturais e culturais do país, e, em 19 de novembro de 1992, a empresa teve a sua sede transferida para Brasília, quando passou a ser vinculada ao Ministério da Indústria, do Comércio e do Turismo.

O Decreto № 2.079, de 26 de novembro de 1996, aprova a primeira Estrutura Regimental, as competências das unidades organizacionais, e o Quadro Demonstrativo dos Cargos, em Comissões Gratificadas do Instituto (vide Anexos 2, 3 e 4). Ele remaneja os cargos comissionados e funções gratificadas do Ministério da 
Administração Federal e Reforma do Estado para a EMBRATUR, e dela para o ministério referido.

Em 1999, a EMBRATUR foi vinculada ao Ministério do Esporte e Turismo, que era responsável integral pela Política Nacional do Turismo, e representou: "atividade decorrente de todas as iniciativas ligadas à indústria do turismo, seja, originárias de setor privado ou público, isolados ou coordenadas entre si” (Dec. Lei $n^{\circ}$ 55/66). Com a criação do Ministério do Turismo, em janeiro de 2003, partes da competência do Instituto são transferidas para esse ministério e distribuídas a quatro órgãos específicos, a saber: a Secretaria de Políticas de Turismo - respondendo pela política nacional e desenvolvimento da área -, a Secretaria de Programas e Desenvolvimento do Turismo - estimulando as iniciativas públicas e privadas de incentivo às atividades turísticas -, o Conselho Nacional do Turismo - que propõe diretrizes e oferece subsídios técnicos para a formulação e acompanhamento da política nacional de turismo - e o Instituto Brasileiro de Turismo - o qual cabe o papel de promover e divulgar o turismo nacional no exterior.

A EMBRATUR hoje corresponde às especificações do decreto $N^{\circ} 4.672$, de 16 de abril de 2003 (vide Anexo 1).

O quadro de empregados da EMBRATUR é composto por 201 colaboradores, desses que 127 são servidores ou funcionários, que entram na empresa por meio de concurso ou ocupam cargo de confiança; 32 são terceirizados e 42 estagiários. A Embratur realiza ações de promoção, marketing e apoio à comercialização dos produtos, serviços e destinos turísticos brasileiros no exterior, com o objetivo de gerar o desenvolvimento social e econômico para o país. 


\subsection{Organograma da EMBRATUR}

\section{Organograma 2 - Estrutura organizacional da EMBRATUR}

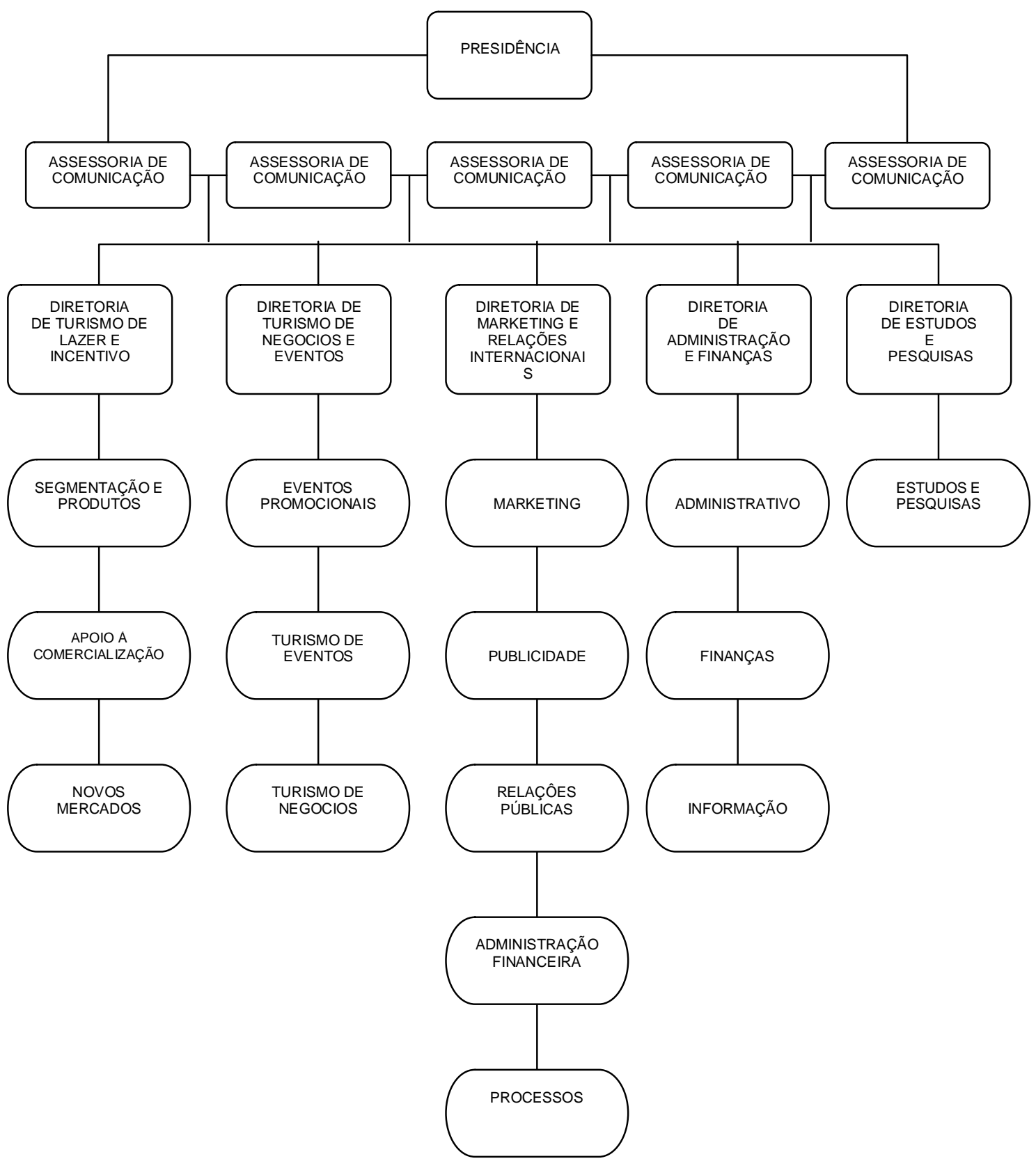




\subsection{O QVT da EMBRATUR}

O programa de Qualidade de Vida no Trabalho da EMBRATUR visa a melhoria da saúde física e mental dos profissionais ligados à ela, com o objetivo de reduzir e prevenir problemas ocupacionais a partir da prática regular das ações dispostas pela empresa. Podem participar do programa todos os servidores, profissionais terceirizados e estagiários da empresa, sendo esse composto por:

- Aula de ginástica laboral,

- Curso de idioma (Inglês e espanhol),

- Confraternização dos aniversariantes do mês,

- Consulta com fisioterapeuta,

- Massagens,

- Confraternização de datas comemorativas (dia das mães, pais, natal),

- Palestras.

- Boletins mensais.

Vale a pena ressaltar que existem ações ainda não colocadas em prática por falta de verbas. 


\section{ANÁLISE DOS DADOS}

\subsection{QUALITATIVA}

Esta pesquisa foi aplicada por meio de instrumento semi-estruturado entregue ao Gerente de $\mathrm{RH}$, a oito gerentes de área, e a vinte outros colaboradores, sendo que retornaram 13 questionários dentre os distribuídos, cujos foram respondidos entre os dias 01/03/2007 e 20/03/2007. Segue, abaixo, a análise das respostas e a transcrição se encontra no apêndice.

De acordo com a entrevista do gerente de Recursos Humanos, percebe-se a importância dada aos programas de QVT da EMBRATUR. Eles são construídos internamente pelo próprio departamento de Recursos Humanos da empresa, e, em alguns casos, contam com ajuda externa, como no caso da aula laboral, que foi um projeto construído juntamente com uma equipe da UnB.

Segundo o próprio $\mathrm{RH}$, o departamento procura sempre acompanhar todas as atividades da QVT e por meio dessa ação, verifica-se a necessidade de possíveis mudanças. O departamento afirma que os programas são de suma importância e considerados uma obrigação para a organização, o que demonstra que a empresa percebe que seu valor é decorrente do valor de seus funcionários e que estes cada vez mais capacitados e valorizados, se tornarão cada vez mais produtivos.

O projeto visa a participação de todos os funcionários da empresa, com o intuito de ajudar no relaxamento, motivação, interatividade, valorização e diminuição de riscos físicos, apostando num retorno de uma maior produção por meios saudáveis.

De acordo com a entrevista, os gerentes de área afirmam que a grande maioria dos funcionários das suas respectivas áreas participam das ações da QVT. Eles consideram que o convite é convincente, mas que alguns empregados ainda resistem em participar. Estes ausentes não vêem ligação entre as ações da QVT, a motivação e a produtividade, e não se interessam em conhecer o acompanhamento do projeto. Os gerentes não conseguem perceber a diferença entre os funcionários praticantes das atividades do programa de qualidade, dos que não as praticam, acreditando assim que estas atividades apenas contribuem para o relaxamento dos 
envolvidos. Os mesmos também afirmam que só frequentam quando têm tempo, mas acham importante investir financeiramente, desde que os funcionários realmente participem.

Em relação as entrevistas com os colaboradores, estes afirmam a participação nas atividades oferecidas pela QVT da Embratur, a maioria mostra preferência pela a aula laboral e as aulas de idiomas. Os respondentes, em geral, reconhecem como benéficas a prática da QVT. Os principais benefícios considerados foram a prevenção de LER/DORT, melhoria do humor, do entrosamento, da disposição, além de sentirem-se relaxados e melhor informados quanto à ergonomia.

A grande maioria dos entrevistados - concordou que as ações ajudam nas relações interpessoais no ambiente profissional, como a união dos departamentos e a interação entre os setores e funcionários, serventes e colaboradores em geral. Eles afirmam, também, perceber diferenças comportamentais - física e mental - dos funcionários que praticam as atividades de QVT para os que não praticam.

Quanto a Produtividade, alguns respondentes acham que a produtividade é resultado de outros fatores, e que os programas da QVT não influenciam nessa área. Porem a maior parte dos entrevistados concorda que as práticas dos programas da QVT resultam numa maior produtividade. Eles consideram que tais programas deixam os funcionários fisicamente e psicologicamente mais relaxados, e que proporcionam um ambiente mais harmonioso, com empregados mais motivados, reduzindo, inclusive, a carga de estresse causado por limites e prazos inerentes ao trabalho.

Os colaboradores se mostram satisfeitos com os programas oferecidos pela EMBRATUR. No entanto algumas respostas indicam a existência de alguns indiferentes: funcionários que não chegam a desgostar, mas que não acreditam que a QVT faça diferença. Alguns dos entrevistados também afirmaram a insatisfação com o programa.

Vale a pena ressaltar que diversas vezes os respondentes reclamam da falta de participação dos diretores e/ou coordenadores da empresa no programa, e afirmam que a participação dos diretores poderia ajudar bem mais nessa interação. 
Outro ponto negativo citado em grande parte das entrevistas foi a falta de acompanhamento do $\mathrm{RH}$. Os funcionários concordam com o investimento financeiro nos programas de QVT, e afirmam que tais programas influenciam no ambiente de forma positiva, contribuindo com a melhoria do humor, interatividade, descontração, valorização do funcionário e produtividade geral da empresa. 


\subsection{PESQUISA QUANTITATIVA}

Com relação ao perfil demográfico dos entrevistados foram consideradas as seguintes informações: sexo, idade, vínculo com a empresa, departamento onde trabalha, hierarquia e o tempo de serviço na empresa. Através dessas informações pode-se chegar a um perfil predominante dos respondentes: $59,7 \%$ são do sexo masculino, 59,8\% possui de 21 anos a 30 anos, 55,6\% são funcionários, 23,6\% trabalham no departamento de eventos, $58,3 \%$ ocupam cargos operacionais e $61,1 \%$ possuem ate 3 anos de trabalho na empresa.

\subsubsection{Tabulações e gráficos}

\section{Questão 1:}

\begin{tabular}{|l|r|rrr|}
\hline \multicolumn{5}{|c|}{ Você conhece o programa QVT da Embratur } \\
\hline & \multicolumn{1}{|c|}{ Freqüência } & Percentual & Percentual Valido & Percentual \\
\hline Sim & 33 & 45,8 & 45,8 & 45,8 \\
Mais ou Menos & 28 & 38,9 & 38,9 & 84,7 \\
Não & 11 & 15,3 & 15,3 & 100,0 \\
\hline Total & 72 & 100,0 & 100,0 & \\
\hline
\end{tabular}
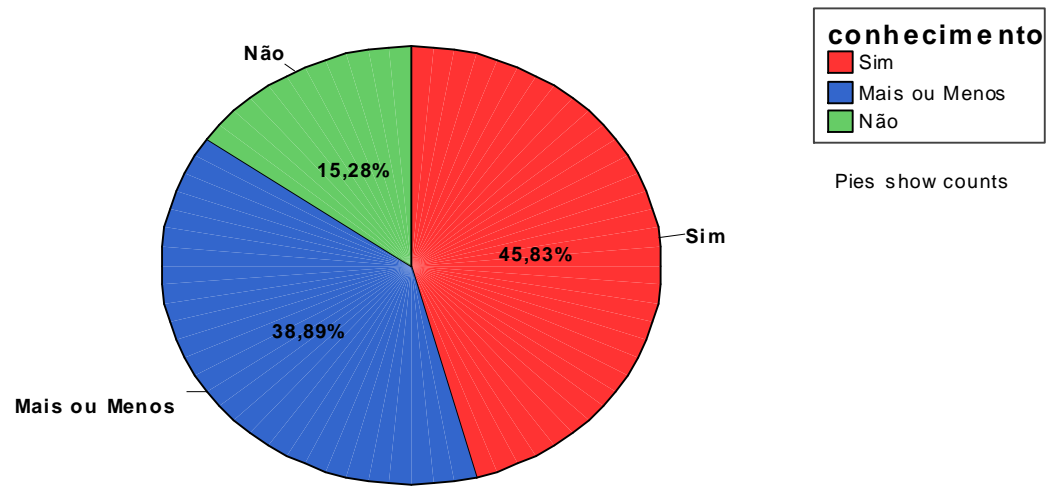

Em relação ao conhecimento sobre o programa de Qualidade de Vida no Trabalho implantado na EMBRATUR, dos 72 respondentes, 84,7\% já ouviram falar do programa, desses, 45,8\% conheciam-no, 38,9\% disseram conhecer mais ou menos, sendo 15,3\% afirmaram desconhecer. Mostrando assim uma boa divulgação do programa pela empresa. 


\section{Questão 2:}

\begin{tabular}{|l|c|c|c|c|}
\hline \multicolumn{5}{|c|}{ Quanto às atividades propostas pelo programa da QVT } \\
\hline & Freqüência & Percentual & Percentual Valido & $\begin{array}{c}\text { Percentual } \\
\text { Cumulativo }\end{array}$ \\
\hline Pouco Interessantes & 21 & 29,2 & 29,2 & 29,2 \\
Interessantes & 26 & 36,1 & 36,1 & 65,3 \\
Indiferentes & 13 & 18,1 & 18,1 & 83,3 \\
Não agradam & 1 & 1,4 & 1,4 & 84,7 \\
Desconheço & 11 & 15,3 & 15,3 & 100,0 \\
\hline Total & 72 & 100,0 & 100,0 & \\
\hline
\end{tabular}

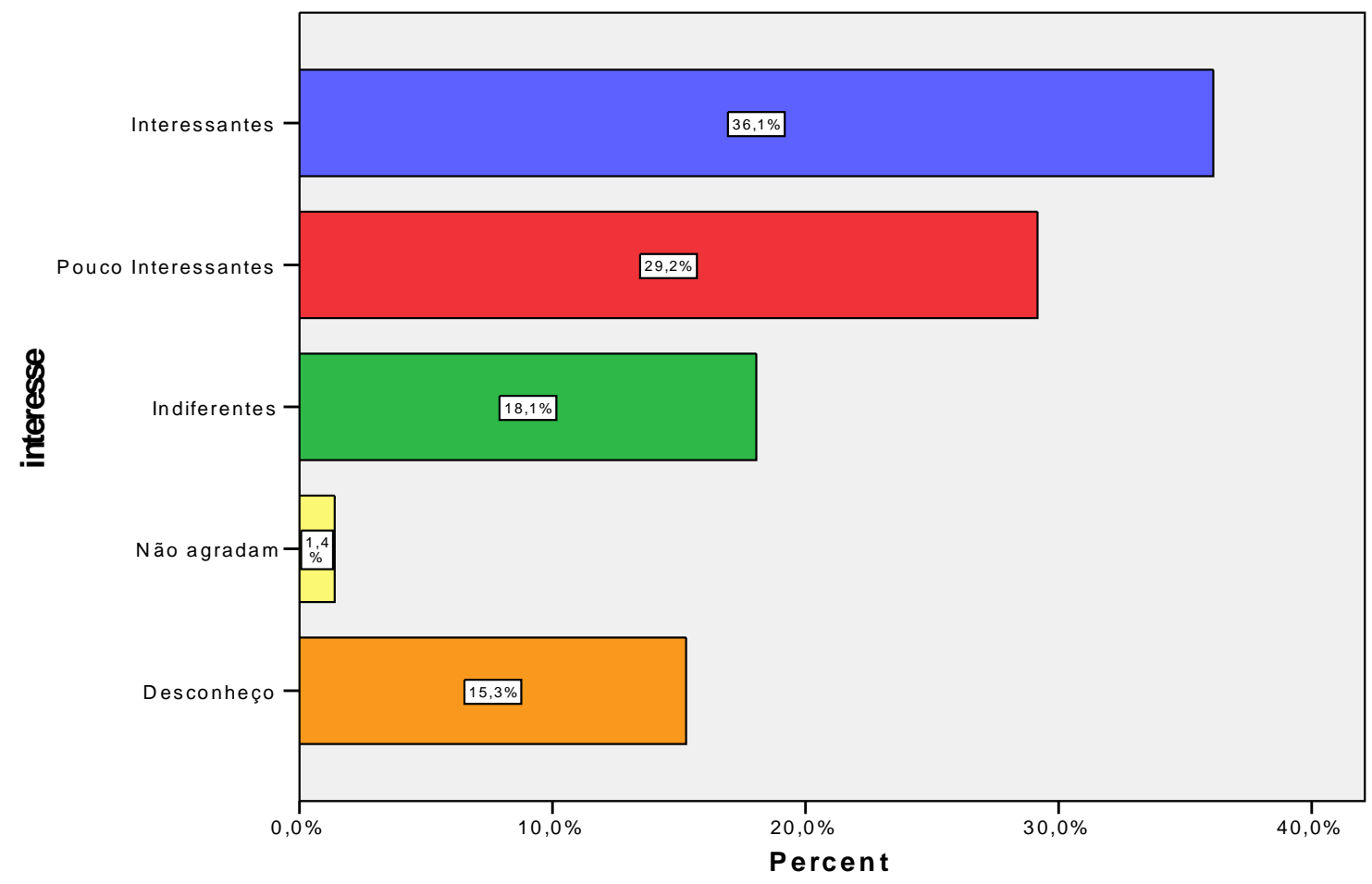

A respeito das atividades propostas pelo programa QVT, a maioria, $36,1 \%$, dos indagados acham que elas são interessantes para os colaboradores, $29,2 \%$ acham pouco interessantes para os colaboradores. 18,1\% acreditam que as ações oferecidas são indiferentes para os demais e apenas 1,4\% opinam que as ações oferecidas pelo programa desagradam. Vale a pena ressaltar ainda que $15,3 \%$ afirmam desconhecer o programa. 


\section{Questão 3:}

\begin{tabular}{|l|c|c|c|c|}
\hline \multicolumn{5}{|c|}{ Qual a atividade que você mais gosta de participar } \\
\hline & Freqüencia & Percentual & Percentual Valido & $\begin{array}{c}\text { Percentual } \\
\text { Cumulativo }\end{array}$ \\
\hline Ginástica Laboral & 25 & 34,7 & 34,7 & 34,7 \\
Curso de Idioma & 12 & 16,7 & 16,7 & 51,4 \\
Massagens & 3 & 4,2 & 4,2 & 55,6 \\
Fisioterapeuta & 2 & 2,8 & 2,8 & 58,3 \\
Palestras & 1 & 1,4 & 1,4 & 59,7 \\
Confraternizações & 16 & 22,2 & 22,2 & 81,9 \\
Não participa & 13 & 18,1 & 18,1 & 100,0 \\
\hline Total & 72 & 100,0 & 100,0 & \\
\hline
\end{tabular}

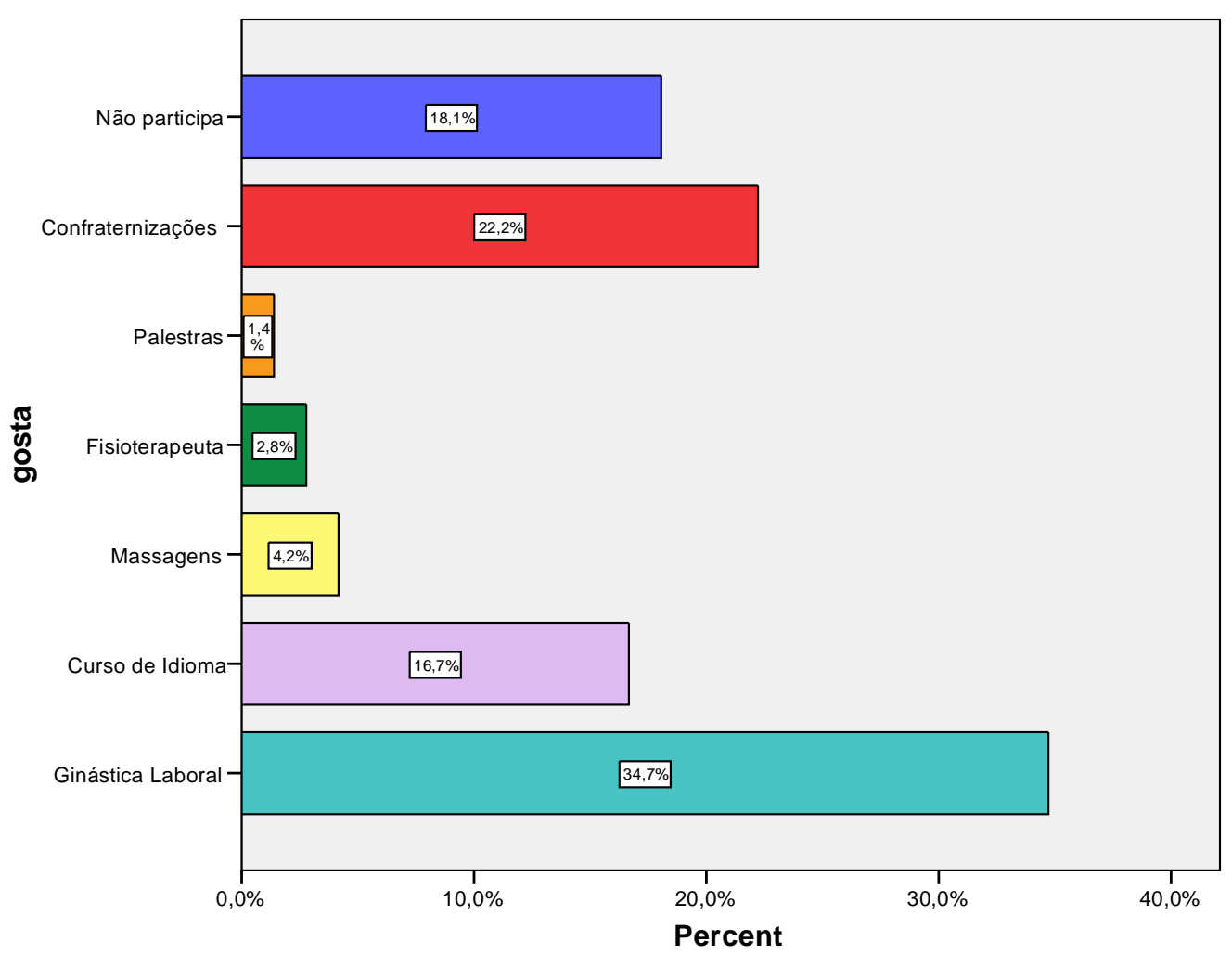

Outro item relevante nas pesquisas é o levantamento em relação a preferência dos respondentes por ações específicas: $34,7 \%$ gostam mais de praticar ginástica laboral, $22,2 \%$ as comemorações em datas festivas, os cursos de idiomas somam um percentual de $16,7 \%$ dos respondente, seguido das massagens com $4,2 \%, 2,8 \%$ indica preferência pelas consultas com o fisioterapeuta e 1,4\% tem preferência pelas palestras. É constatado um índice de 18,1\% para as pessoas que não participam, o que será mais detalhado logo adiante. 


\section{Questão 4:}

\begin{tabular}{|l|c|c|c|c|}
\hline \multicolumn{5}{|c|}{ O programa ajuda em } \\
\hline & Freqüência & Percentual & Percentual Valido & Percentual \\
Cumulativo \\
\hline Produtividade & 16 & 22,2 & 22,2 & 22,2 \\
Motivação & 17 & 23,6 & 23,6 & 45,8 \\
Relaxamento & 11 & 15,3 & 15,3 & 61,1 \\
Integração & 12 & 16,7 & 16,7 & 77,8 \\
Preven. de Doenças & 13 & 18,1 & 18,1 & 95,8 \\
Não ajuda & 3 & 4,2 & 4,2 & 100,0 \\
\hline Total & 72 & 100,0 & 100,0 & \\
\hline
\end{tabular}

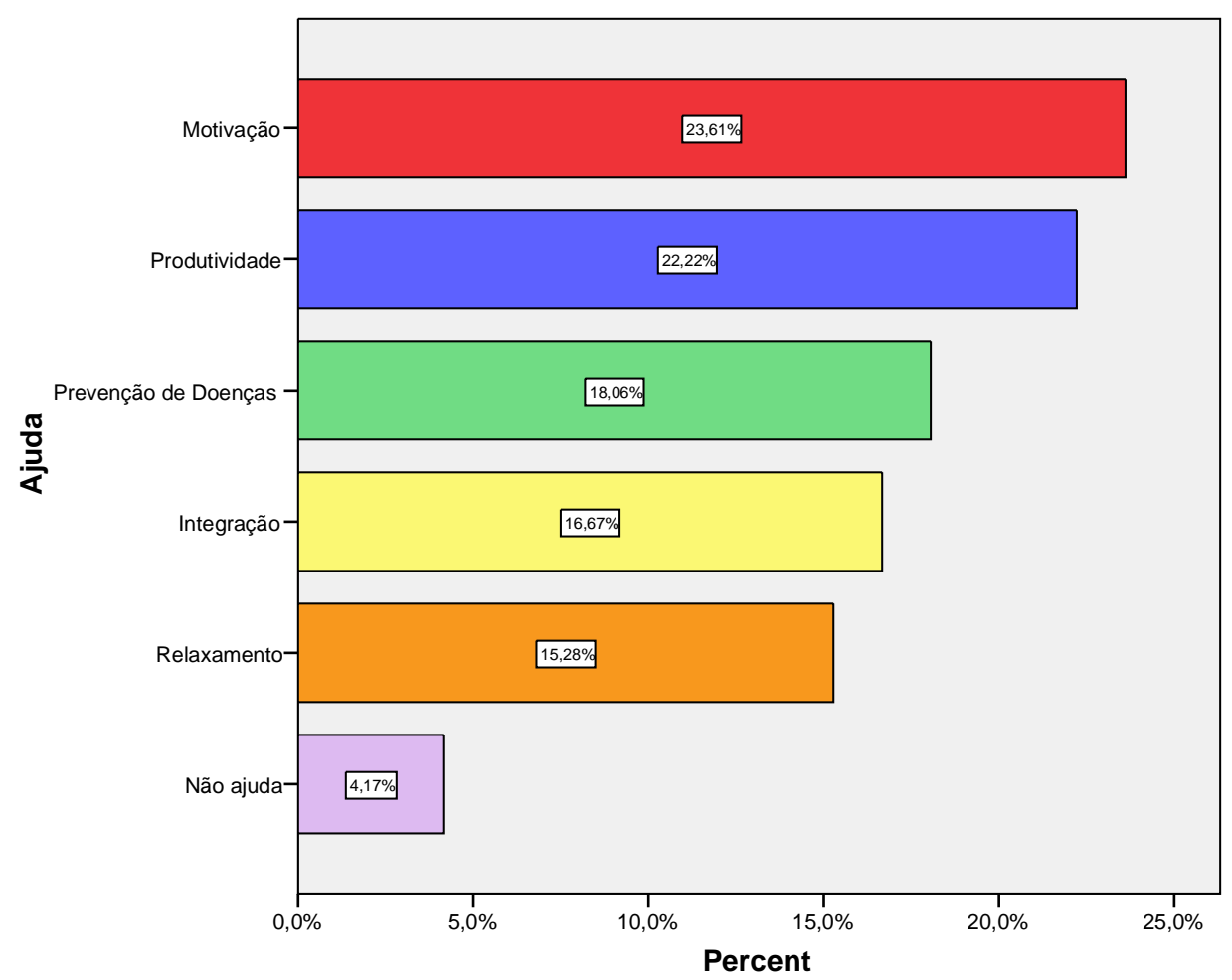

Esta questão teve o intuito de analisar a opinião dos colaboradores em relação aos benefícios trazidos pelo programa da QVT. A maioria dos respondentes, $23,6 \%$, acredita que a motivação é o principal beneficio, seguido da produtividade com $22,2 \%$ e a prevenção de doenças com 18,1\%. Já 16,7\% acreditam na integração dos colaboradores e $15,3 \%$ acredita no relaxamento do ambiente de trabalho. Alguns respondentes não crêem que o programa possa ajudar, sendo esse índice representado por $4,2 \%$ dos entrevistados. Pode-se obter mais informações sobre motivação organizacional no referencial teórico. 


\section{Questão 5:}

\begin{tabular}{|l|c|c|c|c|}
\hline \multicolumn{5}{|c|}{ Quanto a sua participação no programa de QVT } \\
\hline & Freqüência & Percentual & Percentual Valido & $\begin{array}{c}\text { Percentual } \\
\text { Cumulativo }\end{array}$ \\
\hline Sempre & 24 & 33,3 & 33,3 & 33,3 \\
Eventualmente & 32 & 44,4 & 44,4 & 77,8 \\
Não tenho tempo & 13 & 18,1 & 18,1 & 95,8 \\
Não me agrada & 3 & 4,2 & 4,2 & 100,0 \\
\hline Total & 72 & 100,0 & 100,0 & \\
\hline
\end{tabular}

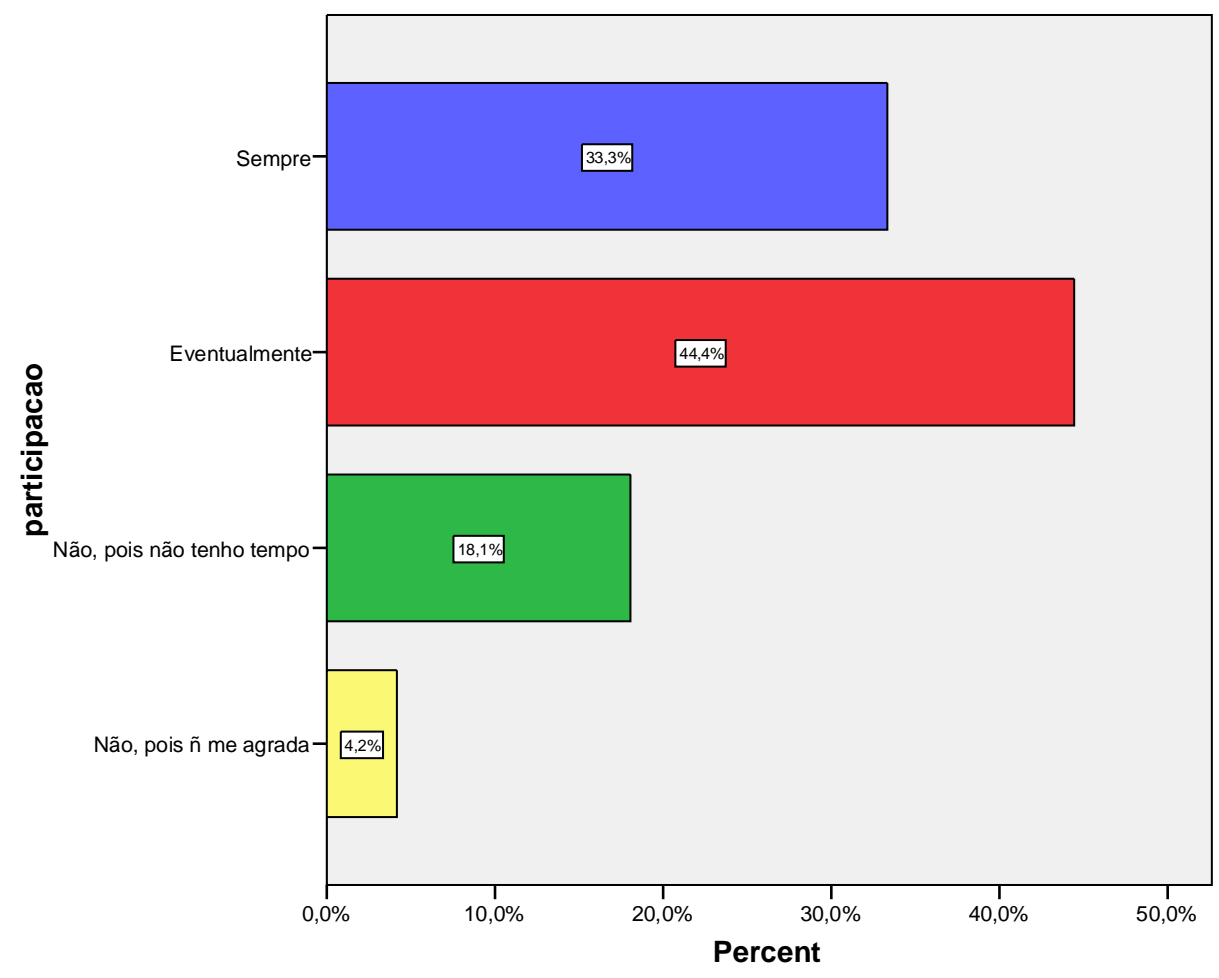

Esta questão aborda a participação dos colaboradores no programa, grande parte dos entrevistados, $77,8 \%$, participa do programa, desses: 44,4 interagem eventualmente, e 33,3\% sempre. Porém $22,3 \%$ não participam: 18,1\% alegam falta de tempo e 4,2\% afirmam não participar por não se agradarem com as atividades oferecidas. Esta questão também faz referência à questão três que cita a falta de participação de alguns colaboradores. 


\section{Questão 6:}

\begin{tabular}{|l|c|c|c|c|}
\hline \multicolumn{5}{|c|}{ Quanto ao investimento financeiro no programa QVT } \\
\hline & Freqüência & Percentual & Percentual Valido & Percentual \\
& 61 & 84,7 & 84,7 & 84,7 \\
\hline Vale a penulativo & 87,5 \\
Não vale a pena & 2 & 2,8 & 2,8 & 100,0 \\
Não sei dizer & 9 & 12,5 & 12,5 & \\
\hline Total & 72 & 100,0 & 100,0 & \\
\hline
\end{tabular}

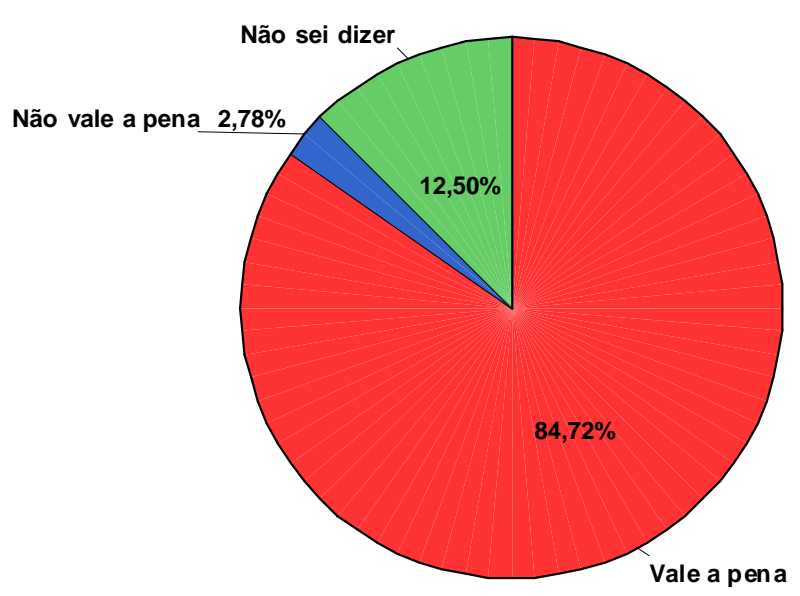

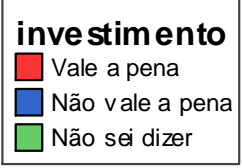

Pies show counts

Esta questão indaga sobre a percepção dos colaboradores em relação ao investimento financeiro da Embratur no programa QVT. Foi percebido que a grande maioria, $84,7 \%$, acredita que o investimento é valido pelos resultados alcançados, sendo $2,8 \%$ crêem no oposto, o investimento não é valido. Alguns respondentes não souberam responder, alegaram não ter retorno sobre os benefícios do programa. Essa falta de retorno sobre o programa pode refletir no funcionário como uma aparente superficialidade podendo causar um desinteresse pelo programa. 


\section{Questão 7:}

\begin{tabular}{|l|c|c|c|c|}
\hline \multicolumn{5}{|c|}{ Gênero } \\
\hline & Freqüencia & Percentual & Percentual Valido & $\begin{array}{r}\text { Percentual } \\
\text { Cumulativo }\end{array}$ \\
\hline Feminino & 29 & 40,3 & 40,3 & 40,3 \\
Masculino & 43 & 59,7 & 59,7 & 100,0 \\
\hline Total & 72 & 100,0 & 100,0 & \\
\hline
\end{tabular}

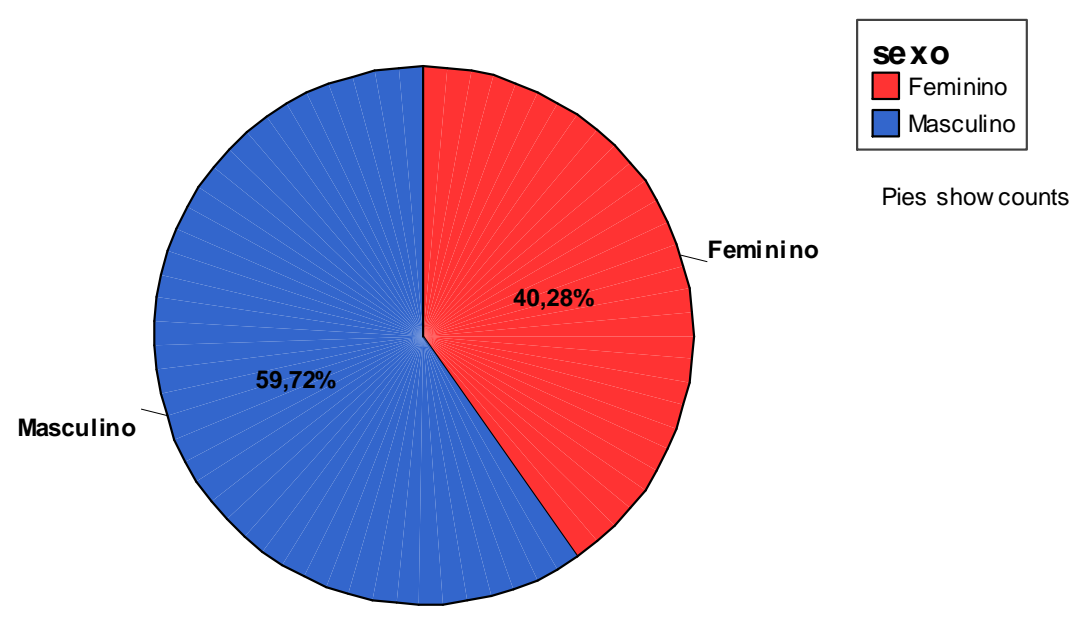

O percentual valido de colaboradores do sexo masculino é de $59,7 \%$ e $40,3 \%$ do sexo feminino. Comprovado que a maioria dos entrevistados são homens. 
Questão 8:

\begin{tabular}{|l|c|c|c|c|}
\hline \multicolumn{5}{|c|}{ Seu vínculo com a Embratur } \\
\hline & Frequeência & Percentual & Percentual Valido & Percentual \\
Cumulativo \\
\hline Funcionário & 42 & 58,3 & 58,3 & 58,3 \\
Terceirizado & 13 & 18,1 & 18,1 & 76,4 \\
Estagiário & 17 & 23,6 & 23,6 & 100,0 \\
\hline Total & 72 & 100,0 & 100,0 & \\
\hline
\end{tabular}

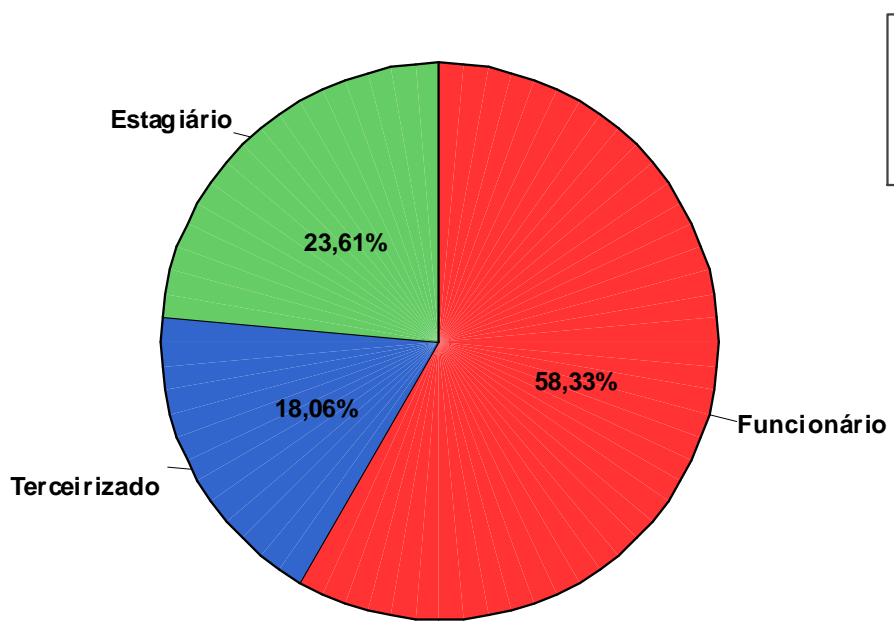

\section{vinculo}

$\square$ Funcionário

Terceirizado

Estagiário

Pies show counts

Em relação ao vínculo dos colaboradores com a Embratur nota-se que 55,6\% dos entrevistados são funcionários, $23,6 \%$ são estagiários e, e 18,1\% são terceirizados. $\mathrm{O}$ quadro de funcionários total da Embratur apresenta o percentual $60 \%$ dos colaboradores como funcionários. Reafirmando a validez da amostra. 


\section{Questão 9:}

\begin{tabular}{|l|c|c|c|c|}
\hline \multicolumn{5}{|c|}{ Departamento onde trabalha } \\
\hline & Frequeencia & Percentual & Percentual Valido & Percentual \\
Cumulativo \\
\hline Eventos & 17 & 23,6 & 23,6 & 23,6 \\
Orçamento & 1 & 1,4 & 1,4 & 25,0 \\
Marketing & 13 & 18,1 & 18,1 & 43,1 \\
RH & 3 & 4,2 & 4,2 & 47,2 \\
Outros & 26 & 36,1 & 36,1 & 83,3 \\
TI & 2 & 2,8 & 2,8 & 86,1 \\
Estudos e Pesquisa & 9 & 12,5 & 12,5 & 98,6 \\
Segurança & 1 & 1,4 & 1,4 & 100,0 \\
\hline Total & 72 & 100,0 & 100,0 & \\
\hline
\end{tabular}

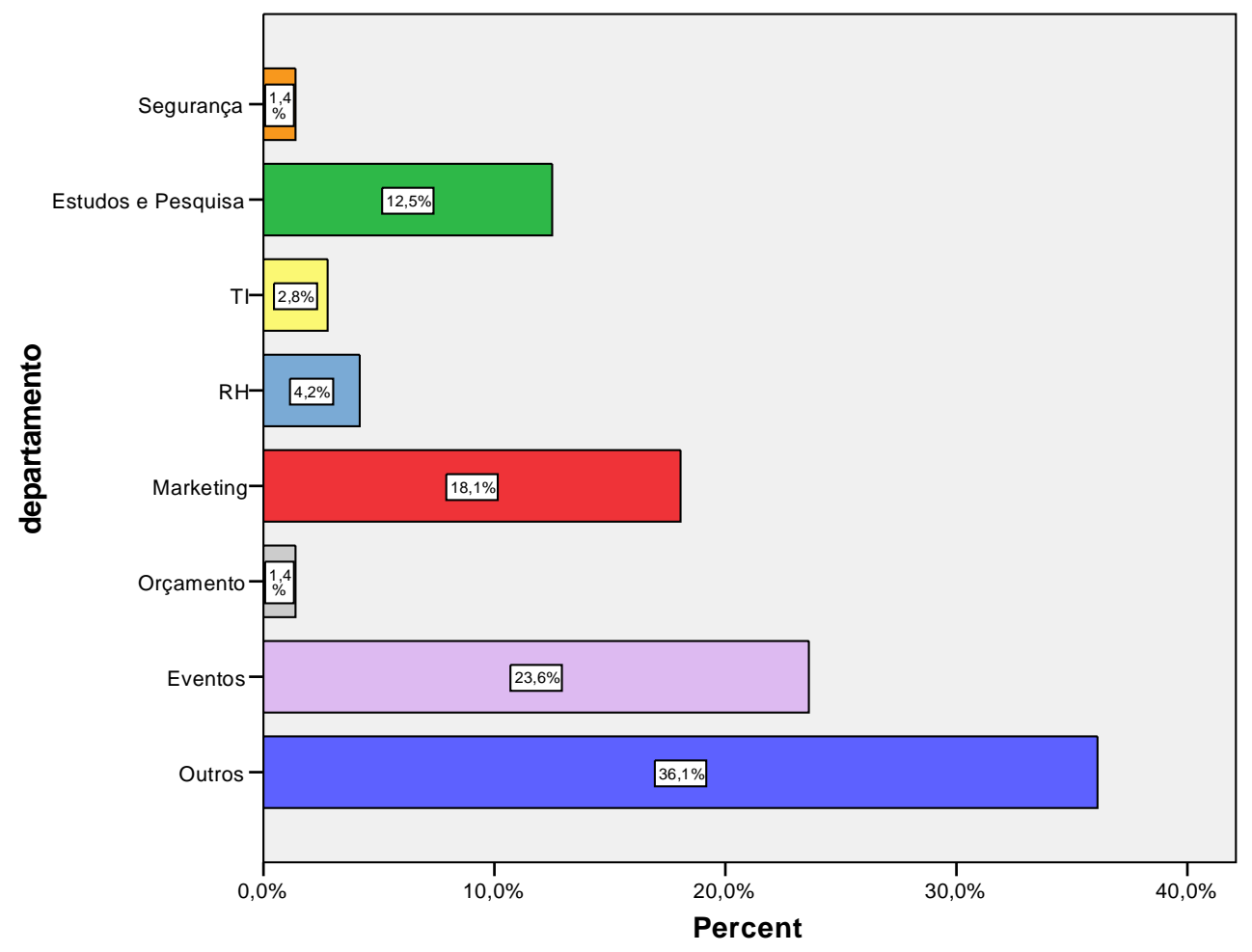

Esta questão identifica o departamento onde trabalha os respondentes: A maioria, $23,3 \%$ trabalha no setor de eventos, seguido do setor de marketing com $18,1 \%$, estudos e pesquisa com $12,5 \%$, recursos humanos com $4,2 \%$, departamento de tecnologia da informação representando um percentual de $2,8 \%$ e Segurança com 1,4\%. É imprescindível ressaltar que $36,1 \%$ dos respondentes não identificam a área em que trabalham. Podendo representar uma falta de interesse, receio da sua identificação ou querer se isentar de qualquer responsabilidade. 
Questão 10:

\begin{tabular}{|l|c|c|c|c|}
\hline \multicolumn{5}{|c|}{ Nível Hierárquico } \\
\hline & Freqüência & Percentual & Percentual Valido & $\begin{array}{c}\text { Percentual } \\
\text { Cumulativo }\end{array}$ \\
\hline Diretor & 3 & 4,2 & 4,2 & 4,2 \\
Gerente & 4 & 5,6 & 5,6 & 9,7 \\
Operacional & 42 & 58,3 & 58,3 & 68,1 \\
Outro & 23 & 31,9 & 31,9 & 100,0 \\
\hline Total & 72 & 100,0 & 100,0 & \\
\hline
\end{tabular}
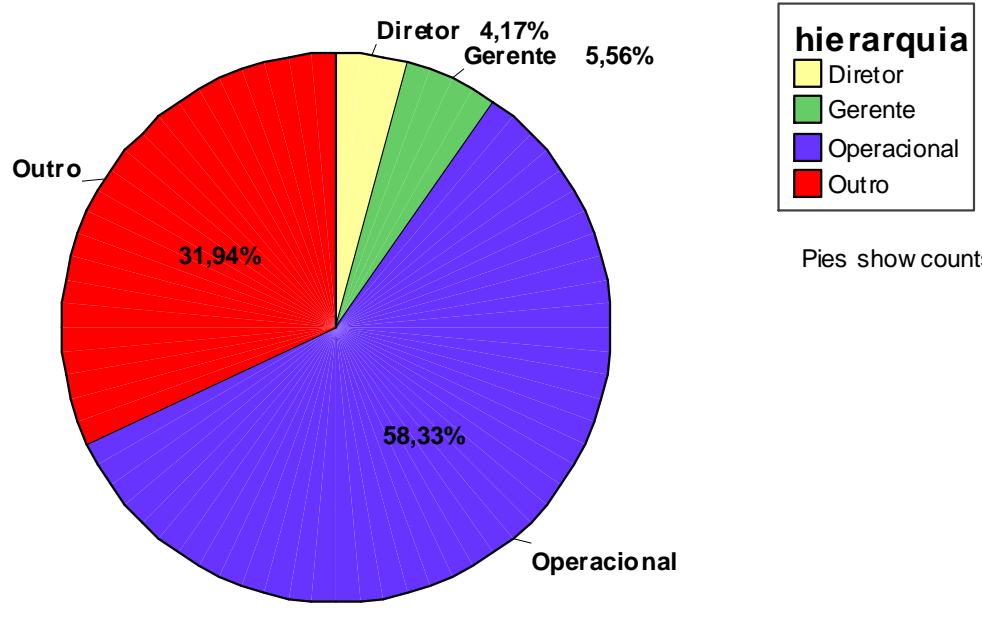

Pies show counts

Esta questão, ainda demográfica, aborda relação hierárquica dos colaboradores entrevistados: $58,3 \%$ são da área operacional, 5,6\% são gerentes e $3 \%$ corresponde ao percentual de diretores. Mais uma vez percebemos um grande número de colaboradores que não identificam suas respostas, novamente podendo ser reflexo de uma falta de interesse, receio de se identificar ou medo de assumir algum tipo de responsabilidade ligado à pesquisa. 


\section{Questão 11:}

\begin{tabular}{|l|c|c|c|c|}
\hline \multicolumn{5}{|c|}{ Idade } \\
\hline & Freqüência & Percentual & Percentual Valido & $\begin{array}{c}\text { Percentual } \\
\text { Cumulativo }\end{array}$ \\
\hline até 20 anos & 4 & 5,6 & 5,6 & 5,6 \\
de 21 a 25 anos & 22 & 30,6 & 30,6 & 36,1 \\
De 26 a 30 anos & 21 & 29,2 & 29,2 & 65,3 \\
De 31 a 35 anos & 8 & 11,1 & 11,1 & 76,4 \\
De 36 a 40 anos & 4 & 5,6 & 5,6 & 81,9 \\
De 41 a 45 anos & 6 & 8,3 & 8,3 & 90,3 \\
Acima de 45 & 7 & 9,7 & 9,7 & 100,0 \\
\hline Total & 72 & 100,0 & 100,0 & \\
\hline
\end{tabular}

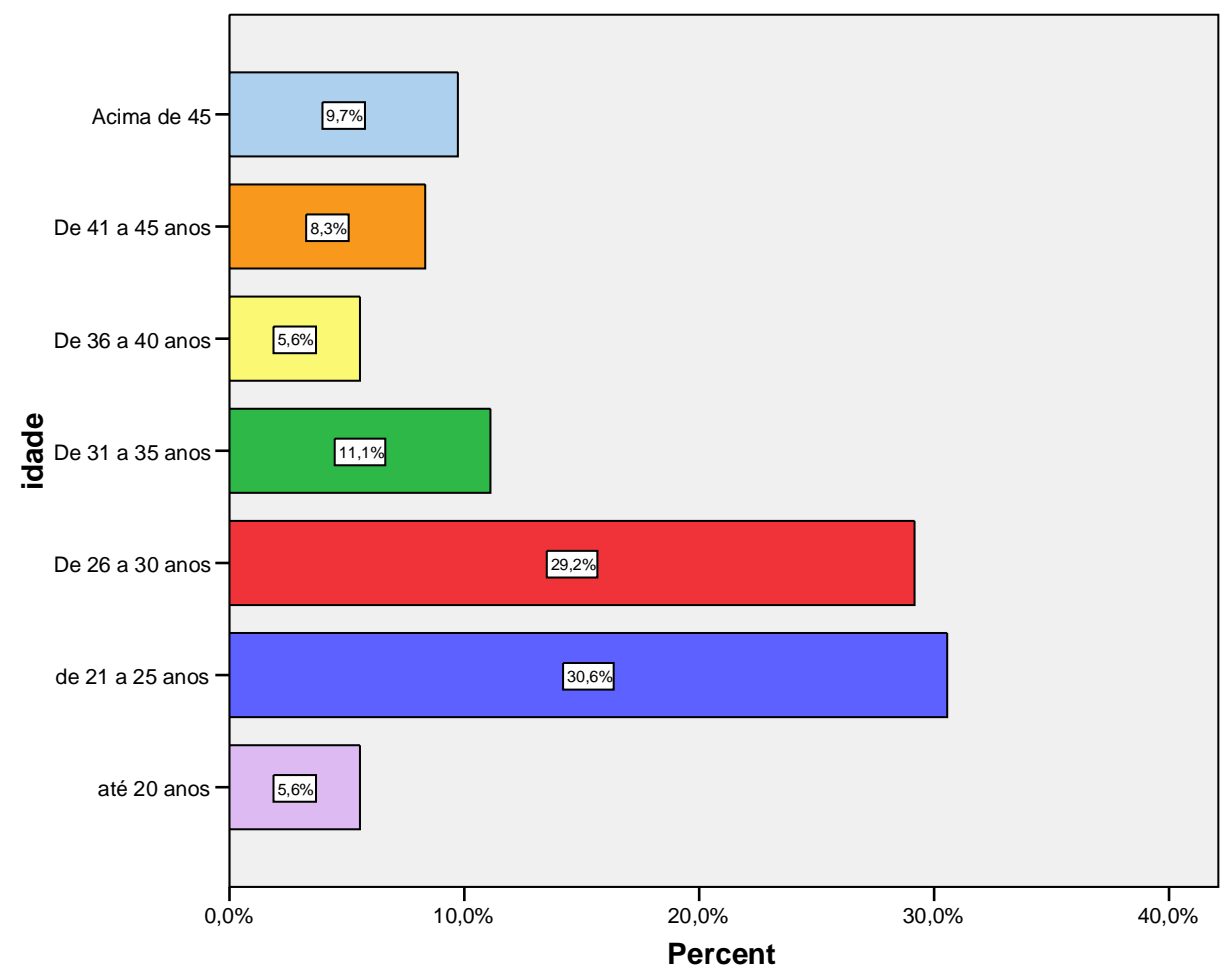

Com a análise das idades fica perceptível que a Embratur possui um perfil jovem de colaboradores de ate 30 anos de idade, representado por $65,3 \%$ dos entrevistados. A maioria dos colaboradores são profissionais recém chegados no mercado de trabalho, mostrando assim, funcionários jovens com conteúdo atualizado. 


\section{Questão 12:}

\begin{tabular}{|l|c|c|c|c|}
\hline \multicolumn{5}{|c|}{ Tempo de serviço na Embratur } \\
\hline & Freqüência & Percentual & Percentual Valido & $\begin{array}{r}\text { Percentual } \\
\text { Cumulativo }\end{array}$ \\
\hline Até 1 ano & 14 & 19,4 & 19,4 & 19,4 \\
1,1 a 3 anos & 22 & 30,6 & 30,6 & 50,0 \\
3,1 até 6 anos & 10 & 13,9 & 13,9 & 63,9 \\
Acima de 6 anos & 26 & 36,1 & 36,1 & 100,0 \\
\hline Total & 72 & 100,0 & 100,0 & \\
\hline
\end{tabular}
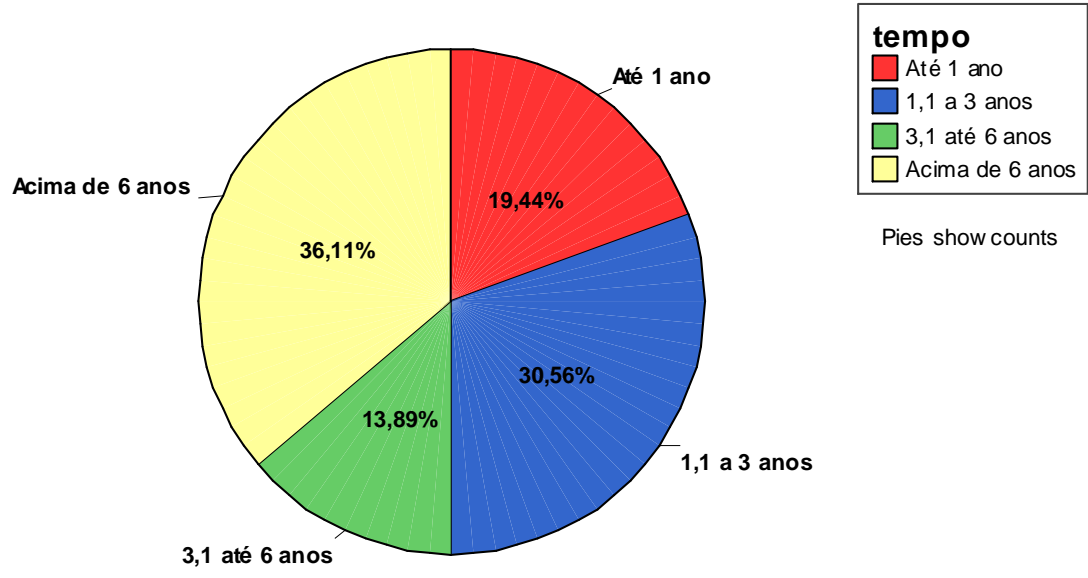

Pies show counts

A maioria dos colaboradores trabalham há mais de seis anos na empresa, representando um percentual de $36,1 \%$ dos entrevistados. Podendo ser caracterizado com um ponto positivo para a Embratur, indicando uma baixa rotatividade o que pode representar um bom clima organizacional. 


\subsubsection{Cruzamentos}

Com o intuito de melhor analisar os dados coletados foram feitos cruzamentos de questões relevantes que merecem uma maior atenção.

Tabela Cruzamento 1 - Vínculo X Conhecimento

\begin{tabular}{|ll|r|r|r|r|}
\hline \multirow{2}{*}{ VINCULO } & & \multicolumn{3}{|c|}{ CONHECIMENTO } & \multicolumn{2}{c|}{ Total } \\
\cline { 3 - 6 } & & \multicolumn{1}{c|}{ Sim } & $\begin{array}{c}\text { Mais ou } \\
\text { Menos }\end{array}$ & Não & \\
\hline Funcionário & Freq & 19 & 20 & 3 & 42 \\
Terceirizado & $\%$ & $26,4 \%$ & $27,8 \%$ & $4,2 \%$ & $58,3 \%$ \\
& Freq & 6 & 3 & 4 & 13 \\
Estagiário & $\%$ & $\mathbf{8 , 3} \%$ & $\mathbf{4 , 2} \%$ & $\mathbf{5 , 6} \%$ & $\mathbf{1 8 , 1} \%$ \\
& Freq & 8 & 5 & 4 & 17 \\
& $\%$ & $\mathbf{1 1 , 1} \%$ & $\mathbf{6 , 9} \%$ & $\mathbf{5 , 6 \%}$ & $\mathbf{2 3 , 6 \%}$ \\
\hline Total & Freq & 33 & 28 & 11 & 72 \\
& $\%$ & $45,8 \%$ & $38,9 \%$ & $15,3 \%$ & $100,0 \%$ \\
\hline
\end{tabular}

Esta tabela representa a relação entre o vínculo de cada entrevistado com o nível de conhecimento sobre o programa. Podemos perceber que dos $45,8 \%$ dos colaboradores que conhecem o programa, mais da metade são funcionários. Dos $15,3 \%$ colaboradores que afirmam não conhecer o programa $\mathbf{8 \%}$ são terceirizados ou estagiários. Essa falta de conhecimento pode representar um menor comprometimento com a empresa por parte dos estagiários e terceirizados, talvez por não serem funcionários eles não estão atentos para os benefícios e atividades propostos pela empresa. Todavia é valido ressaltar que o programa é direcionado para todos os colaboradores. 
Tabela Cruzamento 2 - Vínculo X Preferência

\begin{tabular}{|ll|c|c|c|c|c|c|c|c|}
\hline \multirow{2}{*}{ VínCULO } & \multicolumn{7}{|c|}{ PREFERÊNCIA } & Total \\
\cline { 3 - 11 } & & $\begin{array}{c}\text { Ginást. } \\
\text { Labora } \\
\text { I }\end{array}$ & $\begin{array}{c}\text { Curso } \\
\text { Idioma }\end{array}$ & Massag. & Fisiot. & Palestr & Confrat. & Não participa & \\
\hline Funcionários & Freq & 14 & 8 & 2 & 1 & 0 & 9 & 8 & 14 \\
& $\%$ & $\mathbf{1 9 , 4} \%$ & $\mathbf{1 1 , 1} \%$ & $\mathbf{2 , 8} \%$ & $\mathbf{1 , 4} \%$ &, $0 \%$ & $\mathbf{1 2 , 5} \%$ & $\mathbf{1 1 , 1} \%$ & $19,4 \%$ \\
Terceirizados & Freq & 3 & 3 & 0 & 0 & 0 & 3 & 4 & 3 \\
& $\%$ & $4,2 \%$ & $4,2 \%$ &, $0 \%$ &, $0 \%$ &, $0 \%$ & $4,2 \%$ & $5,6 \%$ & $4,2 \%$ \\
Estagiários & Freq & 8 & 1 & 1 & 1 & 1 & 4 & 1 & 8 \\
& $\%$ & $11,1 \%$ & $1,4 \%$ & $1,4 \%$ & $1,4 \%$ & $1,4 \%$ & $5,6 \%$ & $1,4 \%$ & $11,1 \%$ \\
\hline Total & Freq & 25 & 25 & 12 & 3 & 2 & 1 & 16 & 13 \\
& $\%$ & $34,7 \%$ & $16,7 \%$ & $4,2 \%$ & $2,8 \%$ & $1,4 \%$ & $22,2 \%$ & $18,1 \%$ & $34,7 \%$ \\
\hline
\end{tabular}

De $34,7 \%$ de colaboradores que praticam ginástica laboral $19,4 \%$ são funcionários, de 16,7\% de colaboradores que praticam Curso de idioma 11,1\% são funcionários. Dos $4,2 \%$ de colaboradores que vão para massagens $2,8 \%$ são funcionários, de $2,8 \%$ de colaboradores que praticam se consultam com fisioterapeuta $1,4 \%$ são funcionários, de $22,2 \%$ de colaboradores que vão para confraternizações de data comemorativas $12,5 \%$ são funcionários.

Em qualquer uma das ações do programa pode-se perceber que vínculo empregatício que mais participa das atividades propostas são os funcionário e servidores, os quais representam mais da metade do percentual de cada ação. Reforçando a análise da tabela anterior. 
Tabela Cruzamento 3 - Preferência X Gênero

\begin{tabular}{|ll|c|c|c|c|c|c|c|c|}
\hline \multirow{2}{*}{ GÊNERO } & \multicolumn{7}{|c|}{ PREFERÊNCIA } & Total \\
\cline { 3 - 9 } & & $\begin{array}{c}\text { Ginástica } \\
\text { Laboral }\end{array}$ & $\begin{array}{c}\text { Curso } \\
\text { Idioma }\end{array}$ & Massag & Fisioterap & Palestras & Confrater & $\begin{array}{c}\text { Não } \\
\text { participa }\end{array}$ \\
\hline Feminino & Freq & 10 & 6 & 2 & 1 & 0 & 8 & 2 & 29 \\
& $\%$ & $\mathbf{1 3 , 9 \%}$ & $8,3 \%$ & $2,8 \%$ & $1,4 \%$ &, $0 \%$ & $11,1 \%$ & $2,8 \%$ & $40,3 \%$ \\
\multirow{4}{*}{ Masculino } & Freq & 15 & 6 & 1 & 1 & 1 & 8 & 11 & 43 \\
& $\%$ & $\mathbf{2 0 , 8 \%}$ & $8,3 \%$ & $1,4 \%$ & $1,4 \%$ & $1,4 \%$ & $11,1 \%$ & $\mathbf{1 5 , 3 \%}$ & $59,7 \%$ \\
\multirow{4}{*}{ Total } & Freq & 25 & 12 & 3 & 2 & 1 & 16 & 13 & 72 \\
& $\%$ & $\mathbf{3 4 , 7 \%}$ & $\mathbf{1 6 , 7 \%}$ & $4,2 \%$ & $2,8 \%$ & $1,4 \%$ & $\mathbf{2 2 , 2} \%$ & $\mathbf{1 8 , 1 \%}$ & $100,0 \%$ \\
\hline
\end{tabular}

Por meio desta tabela podemos perceber a relação entre as atividades de que cada colaborador mais gosta participar cruzando com o gênero de cada um deles. $\mathrm{Na}$ maioria dos itens a comparação se mostra bem equilibrada levando em conta que a maior parte dos respondentes são homens. A atividade que a maioria mais gosta é a ginástica laboral, esses índices se comprovam em ambos os gêneros.

Apesar de um baixo índice no quesito palestras, vale a pena ressaltar que a porcentagem total do mesmo é composta apenas por colaboradores do sexo masculino, não existem mulheres entrevistadas que tenham escolhido palestras como atividade preferida. No quesito massagens se nota uma preferência do sexo feminino.

Porém dentre os funcionários que não participam a maior incidência é de homens mostrando um percentual de 15,3\% de homens que não participam, e 2,8\% de mulheres que não participam. 
Tabela Cruzamento 4 - Gênero X Participação

\begin{tabular}{|ll|c|c|c|c|c|}
\hline \multirow{2}{*}{ GÊNERO } & & \multicolumn{4}{|c|}{ PARTICIPACAO } & Total \\
\cline { 3 - 7 } & & Sempre & Eventualmente & $\begin{array}{c}\text { Não, pois } \\
\text { não tenho } \\
\text { tempo }\end{array}$ & $\begin{array}{c}\text { Não, pois } \\
\text { ñ me } \\
\text { agrada }\end{array}$ & \\
\hline Feminino & Freq & 13 & 11 & 4 & 1 & 29 \\
Masculino & $\%$ & $18,1 \%$ & $15,3 \%$ & $5,6 \%$ & $1,4 \%$ & $\mathbf{4 0 , 3 \%}$ \\
& Freq & 11 & 21 & 9 & 2 & 43 \\
Total & $\%$ & $15,3 \%$ & $29,2 \%$ & $12,5 \%$ & $2,8 \%$ & $\mathbf{5 9 , 7} \%$ \\
& Freq & 24 & 32 & 13 & 3 & 72 \\
& $\%$ & $\mathbf{3 3 , 3} \%$ & $\mathbf{4 4 , 4 \%}$ & $\mathbf{1 8 , 1} \%$ & $\mathbf{4 , 2} \%$ & $\mathbf{1 0 0 , 0} \%$ \\
\hline
\end{tabular}

Esta tabela comparou os dados da variável participação com a variável gênero de cada colaborador respondente. A grande maioria participa eventualmente, índice de 44,4 pontos, apresentando um percentual maior de colaboradores do sexo masculino para esse item, já os colaboradores que participam sempre mostram um índice maior de mulheres que participam.

Dos $22,3 \%$ colaboradores que não praticam 15,3 \% são homens e $7 \%$ são mulheres. Ou seja, se isolarmos os colaboradores que não praticam teremos um índice de $68,6 \%$ representados por homens. A maioria dos funcionários alega falta de tempo. Pode-se analisar que dentre os colaboradores que não participam a grande maioria são homens, reforçando a análise da tabela acima. 
Tabela Cruzamento 5 - Benefício X Departamento

\begin{tabular}{|ll|c|c|c|c|c|c|c|c|c|}
\hline \multirow{2}{*}{ BENEFícIOS } & \multicolumn{7}{|c|}{ DEPARTAMENTO } & Total \\
\cline { 3 - 11 } & & Event & Orçam & Market & RH & Outros & TI & DEPES & Segur & \\
\hline Produtivid & Freq & 2 & 0 & 3 & 3 & 5 & 1 & 2 & 0 & 16 \\
& $\%$ & $2,8 \%$ &, $0 \%$ & $4,2 \%$ & $\mathbf{4 , 2} \%$ & $6,9 \%$ & $1,4 \%$ & $2,8 \%$ &, $0 \%$ & $22,2 \%$ \\
Motivação & Freq & 10 & 0 & 1 & 0 & 3 & 0 & 2 & 1 & 17 \\
& $\%$ & $\mathbf{1 3 , 9} \%$ &, $0 \%$ & $1,4 \%$ &, $0 \%$ & $4,2 \%$ &, $0 \%$ & $2,8 \%$ & $1,4 \%$ & $23,6 \%$ \\
Relaxame & Freq & 0 & 0 & 2 & 0 & 7 & 0 & 2 & 0 & 11 \\
& $\%$ &, $0 \%$ &, $0 \%$ & $2,8 \%$ &, $0 \%$ & $9,7 \%$ &, $0 \%$ & $2,8 \%$ &, $0 \%$ & $15,3 \%$ \\
Integração & Freq & 4 & 0 & 3 & 0 & 4 & 0 & 1 & 0 & 12 \\
& $\%$ & $5,6 \%$ &, $0 \%$ & $4,2 \%$ &, $0 \%$ & $5,6 \%$ &, $0 \%$ & $1,4 \%$ &, $0 \%$ & $16,7 \%$ \\
P. doença & Freq & 1 & 1 & 3 & 0 & 5 & 1 & 2 & 0 & 13 \\
& $\%$ & $1,4 \%$ & $1,4 \%$ & $4,2 \%$ &, $0 \%$ & $6,9 \%$ & $1,4 \%$ & $2,8 \%$ &, $0 \%$ & $18,1 \%$ \\
Não ajuda & Freq & 0 & 0 & 1 & 0 & 2 & 0 & 0 & 0 & 3 \\
& $\%$ &, $0 \%$ &, $0 \%$ & $1,4 \%$ &, $0 \%$ & $2,8 \%$ &, $0 \%$ &, $0 \%$ &, $0 \%$ & $4,2 \%$ \\
\hline Total & Freq & 17 & 1 & 13 & 3 & 26 & 2 & 9 & 1 & 72 \\
& $\%$ & $\mathbf{2 3 , 6} \%$ & $1,4 \%$ & $18,1 \%$ & $\mathbf{4 , 2} \%$ & $36,1 \%$ & $2,8 \%$ & $12,5 \%$ & $1,4 \%$ & $100,0 \%$ \\
\hline
\end{tabular}

A tabela acima cruzou os dados referentes aos benefícios obtidos com a pratica das ações do programa de qualidade de vida e com o departamento onde os entrevistados atuam. De acordo com os dados da tabela Benefícios X Departamento vale frisar que a maioria dos colaboradores da área de eventos acredita na motivação como principal beneficio, pode-se obter maiores informações sobre motivação organizacional no referencial teórico.

Percebe-se, ainda, que o departamento de $\mathbf{R H}$ acredita que o principal benefício do programa é a produtividade. Reafirmando o dado da pesquisa qualitativa onde o criador do programa, o gerente de $\mathrm{RH}$ colocou como objetivo do programa o aumento na produtividade, mostra que relaciona com o objetivo final do programa. 
Tabela Cruzamento 6 - Hierarquia X Benefícios

\begin{tabular}{|c|c|c|c|c|c|c|c|c|}
\hline \multirow{2}{*}{\multicolumn{2}{|c|}{ HIERARQUIA }} & \multicolumn{6}{|c|}{ BENEFÍCIOS } & \multirow[t]{2}{*}{ Total } \\
\hline & & \multirow{2}{*}{$\frac{\text { Produtivid }}{0}$} & $\begin{array}{c}\text { Motivaçã } \\
0\end{array}$ & \multirow{2}{*}{$\begin{array}{c}\text { Relaxa } \\
\mathrm{m}\end{array}$} & \multirow{2}{*}{$\frac{\text { Integração }}{0}$} & $\begin{array}{c}\text { Prevenção } \\
\text { de } \\
\text { Doenças }\end{array}$ & $\begin{array}{r}\text { Não } \\
\text { ajuda }\end{array}$ & \\
\hline Diretor & Freq & & 0 & & & 0 & 1 & 4 \\
\hline & $\%$ & ,0\% & $0 \%$ & $4,2 \%$ &, $0 \%$ &, $0 \%$ & $1,4 \%$ & $5,6 \%$ \\
\hline \multirow[t]{2}{*}{ Gerente } & Freq & 1 & 1 & 4 & 0 & 2 & 1 & 9 \\
\hline & $\%$ & $1,4 \%$ & $1,4 \%$ & $5,6 \%$ &, $0 \%$ & $2,8 \%$ & $1,4 \%$ & $12,5 \%$ \\
\hline \multirow[t]{2}{*}{ Operacional } & Freq & 14 & 11 & 2 & 7 & 4 & 0 & 38 \\
\hline & $\%$ & $19,4 \%$ & $15,3 \%$ & $2,8 \%$ & $9,7 \%$ & $5,6 \%$ &, $0 \%$ & $52,8 \%$ \\
\hline \multirow[t]{2}{*}{ Outros } & Freq & 1 & 5 & 2 & 5 & 7 & 1 & 21 \\
\hline & $\%$ & $1,4 \%$ & $6,9 \%$ & $2,8 \%$ & $6,9 \%$ & $9,7 \%$ & $1,4 \%$ & $29,2 \%$ \\
\hline \multirow[t]{2}{*}{ Total } & Freq & 16 & 17 & 11 & 12 & 13 & 3 & 72 \\
\hline & $\%$ & $22,2 \%$ & $23,6 \%$ & $15,3 \%$ & $16,7 \%$ & $18,1 \%$ & $4,2 \%$ & $100,0 \%$ \\
\hline
\end{tabular}

Esta tabela mostra a relação da hierarquia dos colaboradores com os benefícios obtidos por meio do programa. A maior parte dos colaboradores que acreditam na motivação e produtividade como principais benefícios ocupam cargos operacionais. Ressaltando que se pode obter maiores informações sobre motivação organizacional no referencial teórico.

Pode-se perceber que dos $15,3 \%$, que representa o percentual de colaboradores que acredita no relaxamento como o principal benefício do programa, aproximadamente $10 \%$ é representado por diretores e gerente. Ao isolar o item relaxamento como uma variável, pode-se observar que $65,3 \%$ é o percentual representado pelos diretores e gerente. $O$ que reafirma o dado coletado na pesquisa qualitativa, onde os gerentes de áreas declaram acreditar que as atividades do programa são realizadas apenas para o relaxamento, pois não acreditam que isso possa influenciar na produtividade. Essa opinião dos superiores pode ser resultado da falta de participação dos mesmos. 
Tabela Cruzamento 7 - Hierarquia X Participação

\begin{tabular}{|ll|c|c|c|c|c|}
\hline \multirow{2}{*}{ HIERARQUIA } & & \multicolumn{4}{|c|}{ PARTICIPACAO } & Total \\
\cline { 3 - 7 } & & Sempre & Eventualmente & $\begin{array}{c}\text { Não } \\
\text { tenho } \\
\text { tempo }\end{array}$ & $\begin{array}{c}\text { Não } \\
\text { me } \\
\text { agrada }\end{array}$ & \\
\hline Diretor & Freq & 0 & 1 & 2 & 1 & 4 \\
Gerente & $\%$ &, $0 \%$ & $1,4 \%$ & $\mathbf{2 , 8} \%$ & $\mathbf{1 , 4} \%$ & $5,6 \%$ \\
& Freq & 1 & 2 & 6 & 0 & 9 \\
Operacional & $\%$ & $1,4 \%$ & $2,8 \%$ & $\mathbf{8 , 3} \%$ &, $\mathbf{0} \%$ & $12,5 \%$ \\
& Freq & 15 & 20 & 3 & 0 & 38 \\
Outro & $\%$ & $\mathbf{2 0 , 8}$ & $\mathbf{2 7 , 8} \%$ & $4,2 \%$ &, $0 \%$ & $52,8 \%$ \\
& Freq & 8 & 9 & 2 & 2 & 21 \\
& $\%$ & $11,1 \%$ & $12,5 \%$ & $2,8 \%$ & $2,8 \%$ & $29,2 \%$ \\
\hline Total & Freq & 24 & 32 & 13 & 3 & 72 \\
& $\%$ & $\mathbf{3 3 , 3} \%$ & $\mathbf{4 4 , 4} \%$ & $\mathbf{1 8 , 1} \%$ & $\mathbf{4 , 2} \%$ & $100,0 \%$ \\
\hline
\end{tabular}

No quadro Hierarquia X Participação pode-se perceber que dos 22,3\% representa o número de colaboradores que não participam do programa, desses, $12,5 \%$ são diretores e gerentes. Outra analise possível por meio dessa tabela é que desses $22,3 \%$ que não participam 18,1\% alegam falta de tempo. E ainda desses $22,3 \%$ os gerentes e diretores representam $11,1 \%$ dos colaboradores que não participam por falta de tempo. Já por outro lado os colaboradores operacionais apresentam os maiores índices de participação. 
Tabela Cruzamento 8 - Idade X Participação

\begin{tabular}{|lc|c|c|c|cc|}
\hline \multirow{2}{*}{ IDADE } & & \multicolumn{4}{|c|}{ PARTICIPAÇÃO } & \multicolumn{2}{c|}{ Total } \\
\cline { 2 - 7 } & & Sempre & Eventualmente & $\begin{array}{c}\text { Não, pois ñ } \\
\text { tenho tempo }\end{array}$ & $\begin{array}{c}\text { Não, pois ñ } \\
\text { me agrada }\end{array}$ \\
\hline Até 20 anos & Freq & 2 & 2 & 0 & 0 & 4 \\
De 21 a 25 anos & $\%$ & $2,8 \%$ & $2,8 \%$ &, $0 \%$ &, $0 \%$ & $5,6 \%$ \\
& Freq & 7 & 14 & 1 & 0 & 22 \\
De 26 a 30 anos & $\%$ & $\mathbf{9 , 7} \%$ & $\mathbf{1 9 , 4 \%}$ & $1,4 \%$ &, $0 \%$ & $30,6 \%$ \\
& Freq & 6 & 9 & 5 & 1 & 21 \\
De 31 a 35 anos & $\%$ & $\mathbf{8 , 3} \%$ & $\mathbf{1 2 , 5 \%}$ & $\mathbf{6 , 9} \%$ & $\mathbf{1 , 4 \%}$ & $29,2 \%$ \\
& Freq & 4 & 0 & 3 & 1 & 8 \\
De 36 a 40 anos & $\%$ & $5,6 \%$ &, $0 \%$ & $\mathbf{4 , 2} \%$ & $\mathbf{1 , 4 \%}$ & $11,1 \%$ \\
& Freq & 1 & 2 & 1 & 0 & 4 \\
De 41 a 45 anos & $\%$ & $1,4 \%$ & $2,8 \%$ & $1,4 \%$ &, $0 \%$ & $5,6 \%$ \\
& Freq & 2 & 2 & 1 & 1 & 6 \\
Acima de 45 & $\%$ & $2,8 \%$ & $2,8 \%$ & $1,4 \%$ & $\mathbf{1 , 4} \%$ & $8,3 \%$ \\
& Freq & 2 & 3 & 2 & 0 & 7 \\
& $\%$ & $2,8 \%$ & $4,2 \%$ & $2,8 \%$ &, $0 \%$ & $9,7 \%$ \\
\hline Total & Freq & 24 & 32 & 13 & 3 & 72 \\
& $\%$ & $\mathbf{3 3 , 3} \%$ & $\mathbf{4 4 , 4 \%}$ & $\mathbf{1 8 , 1} \%$ & $\mathbf{4 , 2} \%$ & $100,0 \%$ \\
\hline
\end{tabular}

De acordo com a tabela, dos entrevistados que participam sempre a maior incidência é de colaboradores que possuem de 21 a 30 anos, dos colaboradores que participam eventualmente a maior incidência é de respondentes com a mesma idade acima de 21 anos a 30 anos. Dos entrevistados que alegam não participar por falta de tempo possui um perfil de 26 a 35 anos. Já os entrevistados que não participam por não sentir agrado nas atividades propostas não possuem um perfil que possa ser analisado, por se apresentar em diferentes estágios de idade.

Por meio desses dados pode-se afirmar que a maioria dos colaboradores que participam, tanto os que sempre participam como os de participação eventual apresentam um perfil jovem, podendo ter mais disposição e uma opinião mais atual sobre o programa. Já os respondentes que não participam por falta de tempo apresentam um perfil um pouco mais velho, talvez ocupando cargos com mais responsabilidades com isso, possam ter a impressão que o programa seria perda tempo, sem ter crença nos objetivos do mesmo. 
Tabela Cruzamento 9 - Idade X Interesse

\begin{tabular}{|c|c|c|c|c|c|c|c|}
\hline \multirow{2}{*}{ IDADE } & & \multicolumn{5}{|c|}{ INTERESSE } & \multirow[t]{2}{*}{ Total } \\
\hline & & $\begin{array}{c}\text { Pouco } \\
\text { Interessantes }\end{array}$ & $\begin{array}{l}\text { Interes } \\
\text { santes }\end{array}$ & $\begin{array}{l}\text { Indife } \\
\text { rentes }\end{array}$ & $\begin{array}{c}\text { Não } \\
\text { agradam }\end{array}$ & Desconheço & \\
\hline \multirow[t]{2}{*}{ até } & Freq & 1 & 1 & 0 & 0 & 2 & 4 \\
\hline & $\%$ & $1,4 \%$ & $1,4 \%$ & ,0\% & , 0\% & $2,8 \%$ & $5,6 \%$ \\
\hline \multirow[t]{2}{*}{ de 21 a 25} & Freq & 7 & & 4 & 0 & 3 & 22 \\
\hline & $\%$ & $9,7 \%$ & $11,1 \%$ & $5,6 \%$ & ,0\% & $4,2 \%$ & $30,6 \%$ \\
\hline \multirow[t]{2}{*}{ De 26 a 30} & Freq & 7 & & 4 & 1 & 2 & 21 \\
\hline & $\%$ & $9,7 \%$ & $9,7 \%$ & $5,6 \%$ & $1,4 \%$ & $2,8 \%$ & $29,2 \%$ \\
\hline \multirow[t]{2}{*}{ De 31 a 35} & Freq & 1 & 4 & 2 & 0 & 1 & \\
\hline & $\%$ & $1,4 \%$ & $5,6 \%$ & $2,8 \%$ & ,0\% & $1,4 \%$ & $11,1 \%$ \\
\hline \multirow[t]{2}{*}{ De 36 a 40} & Freq & 2 & & 1 & 0 & 0 & \\
\hline & $\%$ & $2,8 \%$ & $1,4 \%$ & $1,4 \%$ & , 0\% & ,0\% & $5,6 \%$ \\
\hline \multirow{2}{*}{ De 41 a 45} & Freq & 0 & 3 & 1 & 0 & 2 & 6 \\
\hline & $\%$ & ,0\% & $4,2 \%$ & $1,4 \%$ & , 0\% & $2,8 \%$ & $8,3 \%$ \\
\hline \multirow{2}{*}{$\begin{array}{l}\text { Acima de } \\
45\end{array}$} & Freq & 3 & 2 & 1 & 0 & 1 & 7 \\
\hline & $\%$ & $4,2 \%$ & $2,8 \%$ & $1,4 \%$ &, $0 \%$ & $1,4 \%$ & $9,7 \%$ \\
\hline \multirow[t]{2}{*}{ Total } & Freq & 21 & 26 & 13 & 1 & 11 & 72 \\
\hline & $\%$ & $29,2 \%$ & $36,1 \%$ & $18,1 \%$ & $1,4 \%$ & $15,3 \%$ & 0,0 \\
\hline
\end{tabular}

Os colaboradores que acham as atividades do programa interessantes representam $36,1 \%$ do total, desses, $20,8 \%$ tem de 21 anos à 30 anos de idade. Podendo assim indicar que o programa seja mais interessante aos colaboradores jovens.

Já a maioria dos colaboradores que desconhecem o programa possuem ate 20 anos, podendo ser caracterizados por estagiários, como indicou a tabela 1 e 2 de cruzamento. E dos colaboradores que acham as atividades desinteressantes ou indiferentes esta sendo representado por um percentual de $9,8 \%$ de idade entre 26 e 35 anos. 
Tabela Cruzamento 10 - Gênero X Interesse

\begin{tabular}{|c|c|c|c|c|c|c|c|}
\hline \multirow{2}{*}{ GÊNERO } & & \multicolumn{5}{|c|}{ INTERESSE } & \multirow[t]{2}{*}{ Total } \\
\hline & & $\begin{array}{c}\text { Pouco } \\
\text { Interessantes }\end{array}$ & Interessantes & Indiferentes & $\begin{array}{c}\text { Não } \\
\text { agradam }\end{array}$ & $\begin{array}{l}\text { Desconh } \\
\text { eço }\end{array}$ & \\
\hline \multirow[t]{2}{*}{ Feminino } & Freq & 9 & 12 & 4 & 0 & 4 & 29 \\
\hline & $\%$ & $12,5 \%$ & $16,7 \%$ & $5,6 \%$ & ,0\% & $5,6 \%$ & $40,3 \%$ \\
\hline \multirow[t]{2}{*}{ Masculino } & Freq & 12 & 14 & 9 & 1 & 7 & 43 \\
\hline & $\%$ & $16,7 \%$ & $19,4 \%$ & $12,5 \%$ & $1,4 \%$ & $9,7 \%$ & $59,7 \%$ \\
\hline \multirow[t]{2}{*}{ Total } & Freq & 21 & 26 & 13 & 1 & 11 & 72 \\
\hline & $\%$ & $29,2 \%$ & $36,1 \%$ & $18,1 \%$ & $1,4 \%$ & $15,3 \%$ & $100,0 \%$ \\
\hline
\end{tabular}

Os colaboradores que acham as atividades do programa interessantes são representados pelo percentual de 36,1 pontos, desses, a maioria são mulheres,

Já os respondentes que se sentem indiferentes ao programa ou não acham o programa agradável se apresenta com um maior número de homens. 
Tabela Cruzamento 11 - Tempo X Interesse

\begin{tabular}{|c|c|c|c|c|c|c|c|}
\hline \multirow[b]{2}{*}{ TEMPO } & & \multicolumn{5}{|c|}{ INTERESSE } & \multirow[t]{2}{*}{ Total } \\
\hline & & $\begin{array}{c}\text { Pouco } \\
\text { Interessante }\end{array}$ & ressante & Indiferente & $\begin{array}{l}\text { Não } \\
\text { agrada }\end{array}$ & conheço & \\
\hline Até 1 & Freq & 5 & 6 & 1 & 0 & 2 & 14 \\
\hline & $\%$ & $6,9 \%$ & $8,3 \%$ & $1,4 \%$ &, $0 \%$ & $2,8 \%$ & $19,4 \%$ \\
\hline 3 anos & $\begin{array}{l}\text { Freq } \\
\%\end{array}$ & $\begin{array}{c}5 \\
6.9 \%\end{array}$ & $\begin{array}{c}8 \\
11.1 \%\end{array}$ & $\begin{array}{c}4 \\
5.6 \%\end{array}$ & $\begin{array}{c}1 \\
1.4 \%\end{array}$ & $\begin{array}{c}4 \\
56 \%\end{array}$ & $\begin{array}{c}22 \\
30.6 \%\end{array}$ \\
\hline 3,1 até 6 anos & Freq & 1 & $\begin{array}{l}5 \\
60 \%\end{array}$ & 2 & 0 & $\begin{array}{l}2 \\
20 \%\end{array}$ & $\begin{array}{c}10 \\
130 \%\end{array}$ \\
\hline Acima de 6 & $\begin{array}{l}\% \\
\text { Freq }\end{array}$ & $\begin{array}{c}1,4 \% \\
10\end{array}$ & $\begin{array}{c}6,9 \% \\
7\end{array}$ & $\begin{array}{c}2,8 \% \\
6\end{array}$ & $\begin{array}{c}, 0 \% \\
0\end{array}$ & $\begin{array}{c}2,8 \% \\
3\end{array}$ & $\begin{array}{c}13,9 \% \\
26\end{array}$ \\
\hline & $\%$ & $13,9 \%$ & $9,7 \%$ & $8,3 \%$ &, $0 \%$ & $4,2 \%$ & $36,1 \%$ \\
\hline Tota & $\begin{array}{l}\text { Freq } \\
\%\end{array}$ & $\begin{array}{c}21 \\
29,2 \%\end{array}$ & $\begin{array}{c}26 \\
36,1 \%\end{array}$ & $\begin{array}{c}13 \\
\mathbf{1 8 , 1} \%\end{array}$ & $\begin{array}{c}1 \\
1,4 \%\end{array}$ & $\begin{array}{c}11 \\
15,3 \%\end{array}$ & $\begin{array}{c}72 \\
100,0 \%\end{array}$ \\
\hline
\end{tabular}

Esta tabela analisa a relação do tempo de serviço e do interesse dos colaboradores. $36,1 \%$ É o percentual de colaboradores que acham o programa interessante, dessa fatia $11,1 \%$ possui de entre 1 ano e 1 mês ate 3 anos na empresa. Os colaboradores que acham pouco interessante o programa representam $29,2 \%$ do total, dessa fatia $13,9 \%$ possui mais do que 6 anos na empresa. Os colaboradores que se sentem indiferentes ao programa representa $18,1 \%$ do total, dessa fatia 8,3\% possui acima de 6 anos trabalhando na Embratur.

Esses dados indicam que os colaboradores que possuem mais tempo de casa tendem a não se interessar pelo programa, ou se mostrando indiferente. Esses índices podem ser reflexos de funcionários que já estão perto de se aposentar e com isso não acreditem que existam benefícios a curto prazo ou podem também pensar de forma mais conservadora não acreditando em algum tipo de conseqüência positiva. 


\subsection{SUGESTÕES DOS COLABORADORES}

Após a coleta dos dados das pesquisas quantitativas e qualitativas foi apontado as principais sugestões dos colaboradores para a melhoria do programa de qualidade de vida na Embratur.

1 - Programa ser melhor divulgado entre a equipe;

2 - Música ambiental para as laborais;

3 - Mais dinâmicas de grupo e palestras sobre o corpo e saúde;

4 - Melhorias: aquisições de bastões, elásticos, bolas, colchonetes, melhores equipamentos para os funcionários, como: cadeiras adequadas, teclados ergonômicos, mesas apropriadas para o manuseio dos computadores, fones que substituam o telefone;

5 - Solicitação de uma participação mais ativa dos colaboradores que ocupam os cargos gerenciais, como coordenadores, gerentes e diretores;

6 - Sala específica para as atividades, principalmente de fisioterapia;

7 - Contratação de um psicólogo para atendimento aos servidores;

8 - Novidades nas atividades de confraternização, principalmente aniversariantes do mês. 


\section{CONSIDERAÇÕES FINAIS}

As empresas estão tornando-se cada vez mais conscientes sobre a importância da qualidade de vida no trabalho. É possível perceber o crescente comprometimento delas para com os funcionários, passando a ser estes a principal base da nova organização, envolvendo-os em diversos níveis, sendo abordados não mais como meros recursos, mas sim, como parceiros.

O principal motivo para se investir em qualidade de vida é a própria sobrevivência da organização. Observa-se em todos os setores uma forte tendência de resgatar o lado humano, já que, para crescer, é necessário excelência no que se faz, o que só é possível obter quando se leva em conta o principal capital de uma empresa, ou seja, seus recursos humanos.

Quando o trabalhador não se sente satisfeito, muitos problemas, como 0 estresse disfuncional, podem vir à tona, levando à conseqüências mais graves, por exemplo, o alcoolismo e uso de drogas. Existem várias soluções comuns para se reduzir o estresse no ambiente profissional, o aumento de horas de sono, alimentação mais balanceada, um serviço mais adequado, planejamento e organização das atividades diárias, a busca de aconselhamento, e até opções mais exóticas, como a meditação transcendental.

É neste ponto que se insere a preocupação da empresa com a saúde e a qualidade de vida de seus colaboradores. É necessário o bem-estar do funcionário, conscientizando-o da importância do seu trabalho na organização, e da possibilidade de influir no processo de produção. Caso contrário haverá uma quebra de produtividade, aumento do estresse causando o burnout, podendo este desdobrarse em outros problemas de saúde. Apesar da importância da qualidade de vida no trabalho, e do crescente investimento das organizações nos programas para tal, ainda existem diferentes visões sobre tais esquemas.

Além do problema teórico, existe também a questão prática da empresa investir em QVT e o funcionário não dar credibilidade ao programa, seja por falta de informação, por causa da aparente superficialidade, ou por ser aplicado sem a crença em sua utilidade para as condições de trabalho. Por estas razões, considera- 
se relevante verificar-se a percepção dos funcionários da EMBRATUR a respeito do programa de QVT implantado na organização. Neste estudo, foi observado as diferentes visões em relação ao programa de qualidade de vida, somado a uma análise sensitiva de uma amostra de colaboradores.

O objetivo geral desse trabalho foi realizar um estudo analisando o programa de qualidade de vida no trabalho da Embratur segundo a visão dos seus colaboradores. Os objetivos específicos foram: fazer a analise de 3 visões dentro da organização estudada, a visão dos criadores do programa, a visão dos gerentes ou supervisores e a visão dos colaboradores em geral; identificar os pontos de melhoria no programa e apontar sugestões. Esses objetivos fora alcançados conforme 0 conteúdo desse e dos capítulos anteriores.

Ao implantar a QVT, o grupo organizador do projeto - o Departamento de $\mathbf{R H}$-, objetivou conciliar resultados positivos tanto para os funcionários quanto para a companhia. O programa baseou-se na melhoria do clima organizacional, do bemestar geral, na saúde dos trabalhadores, e na diminuição de riscos físicos, com intuito de aumentar a sua motivação e comprometimento, resultando, assim, no aumento da produtividade por meios saudáveis. Porém, na visão dos gerentes de área, as atividades da QVT proporcionam apenas relaxamento: eles não acham que essas possam concorrer para a melhoria dos resultados das tarefas, o que revela que os objetivos dessas ações não foram passados para esses gerentes.

Sob a visão dos colaboradores, o programa é bem aceito. Praticamente todos percebem algum tipo de beneficio, tanto físico quanto mental ou comportamental, Eles também concordaram com a influência que estas exercem sobre a produção, embora não dispusessem de informações sobre os objetivos do programa.

Como foi dito acima, o RH acredita que é possível obter uma maior produção oferecendo-se melhores condições de trabalho, eqüalizando desta maneira, os benefícios entre a empresa e seus colaboradores. Os gerentes de área desconhecem como funciona o acompanhamento em relação aos programas QVT, e, concomitantemente, na visão dos colaboradores da EMBRATUR, a maioria queixou-se justamente da falta de acompanhamento dos Recursos Humanos. 
Outra reclamação citada diversas vezes nas entrevistas foi a ausência dos superiores hierárquicos nas práticas da QVT. O $\mathrm{RH}$, ao elaborar o programa, visou a participação de todos os colaboradores - dos diretores aos funcionários e serventes. $\mathrm{Na}$ avaliação dos depoimentos dos gerentes de área, eles afirmaram que não participam das ações fornecidas pela empresa, pois alegam falta de tempo.

$\mathrm{Na}$ amostra quantitativa, pode-se verificar um maior numero de colaboradores do sexo masculino. Em relação ao vínculo dos colaboradores a maioria dos entrevistados eram servidores ou funcionários da EMBRATUR. Os colaboradores da EMBRATUR em sua grande maioria já conhecem ou já ouviram falar sobre o Programa de qualidade de vida. A maioria dos respondentes, afirmou que a que a motivação é o principal beneficio, seguido da produtividade e a prevenção de doenças. Outros acreditam na integração dos colaboradores e no relaxamento do ambiente de trabalho. Existe também um pequeno percentual que não acredita que o programa possa contribui em nada.

Quanto à participação no programa, uma maior porcentagem se mostra interessada, e pratica as atividades, enquanto uma pequena porcentagem dos entrevistados sente que elas não agradam aos colaboradores. É relevante frisar que alguns dos respondentes afirmaram não participar da QVT por falta de tempo, questão também respondida anteriormente pelos gerentes de área na análise qualitativa.

Apesar da maior parte dos respondentes afirmarem conhecer o projeto, diversas vezes sugeriu-se que houvesse uma maior divulgação dos resultados obtidos através do programa, pois o investimento nele é visto por essa parcela como uma ação válida, levando-se em conta os resultados os quais se pode alcançar.

Os pontos de melhoria do programa podem ser apontados de forma bem resumida: Existe uma falha na comunicação interna da organização, essa desinformação pode ser representada pela falta de feedback em relação ao programa. Essa falha também reflete na ausência dos gerentes e diretores de áreas, que, por não saber dos objetivos e resultados do programa o tratam como uma atividade que se relaciona apenas ao lazer, acreditando que o único benefício trazido com a prática das atividades são funcionários mais relaxados. 
Essa descrença no programa leva a falta de incentivo, fazendo que os gerentes e diretores não participem podendo julgar como perda de tempo, como diversas vezes foi citado por parte dos superiores, e também podemos analisar na tabela Hierarquia X Benefício, uma suposta falta de tempo como justificativa para a não participação do programa. Conseqüentemente essa situação pode refletir de forma indireta no restante dos colaboradores, influenciando-os a tomar a mesma decisão.

Como sugestões é preciso uma maior divulgação interna sobre os objetivos e resultados alcançados. Os funcionários se comprometerão com mais afinco em qualquer atividade dentro da empresa ao saberem mais sobre ela. É de suma importância que os organizadores mostrem os benefícios trazidos pela prática do programa QVT.

Outra sugestão é estimular a participação dos supervisores. Para que a implantação alcance suas metas, deve-se estimular a cooperação e a participação de todos os colaboradores. Ao conceberem um programa de qualidade de vida é preciso perceber que o mesmo não será implantado com sucesso se não houver um efetivo envolvimento dos empregados, atuando com satisfação e motivação para a realização de suas tarefas.

A integração dos supervisores nas atividades é essencial para estimular a vinda dos demais, pois estes são exemplos para os subordinados. Dentro de uma moderna gestão empresarial é preciso fugir do autoritarismo, abrindo-se ao diálogo e à tolerância ao estimular a cooperação, evitando a competição entre departamentos e indivíduos, pois, além da otimização do processo, esse contato é, também, uma forma de quebrar uma imagem hierarquizada dos funcionários, ajudando a correlação entre todos.

Por meio do cruzamento de dados tornou-se perceptível um perfil dos colaboradores que participam e se interessam pelo programa e dos colaboradores que menos se interessam e não tem participação ativa no programa, sendo esses colaboradores homens acima de 26 anos com mais tempo de casa, que ocupa cargos superiores. A sugestão, neste caso, é fazer uma pesquisa limitando esse 
perfil de colaboradores desinteressados e através da analise dessa criar estímulos para incentivá-los a participar.

Dentro do ambiente coorporativo a motivação de cada cliente interno é fundamental para o produto final. A satisfação organizacional de cada colaborador reflete em uma melhora no desempenho das tarefas dos mesmos, o que resultará na melhoria do produto.

Com relação ao presente estudo de caso, a motivação e satisfação dos colaboradores da Embratur - Instituto que possui finalidade de "vender" o produto turístico: Brasil no exterior - se refletirá na excelência da função de cada um deles resultando no aumento da qualidade dos produtos/serviços e mais adiante impactando pontos positivos no sistema turístico.

Os programas de QVT fortalecem cada vez mais a qualidade dos relacionamentos entre empresa e empregados, alcançando, através deles, resultados eficazes e satisfatórios para as duas partes envolvidas. Mas, para que isso ocorra e se mantenha, é essencial a existência da conscientização interna sobre a importância do investimento no bem-estar dos funcionários, dados os benefícios trazidos pelo programa.

Conclui-se, portanto, que o programa de Qualidade de Vida na EMBRATUR, apesar de ser bem aceito pela maioria dos colaboradores, necessita de algumas mudanças internas para alcançar os objetivos fixados pelo $\mathrm{RH}$. 


\section{REFERÊNCIAS BIBLIOGRÁFICAS}

ASSOCIAÇÃO BRASILEIRA DE QUALIDADE DE VIDA - ABQV. Banco de dados. Disponível em: http://www.abqv.org.br, acesso em 23/10/2006.

SUBCHEFIA PARA ASSUNTOS JURÍDICOS DA PRESIDÊNCIA DA REPÚBLICA. (BRASIL) Decreto no 4.672, de 16 de abril de 2003. Disponível em: http://www.planalto.gov.br/ccivil_03/decreto/2003/D4672.htm, acesso em 21/03/2007.

BEKIN, Saul faingaus. Conversando com Endomarketing. São Paulo: Makron Books, 1995.

BOM SUCESSO, Edina de Paula. Relações Interpessoais e Qualidade de Vida. Rio de Janeiro: Qualitymark, 2003.

BRUM, Analisa de Medeiros. Endomarketing como estratégia de gestão: encante seu cliente interno. Porto Alegre: L\&PM, 1998.

CAVERSAN, Luis. Embratur 40 anos. Brasília: 2006

CERVO, Amado L.; BERVIAN Pedro A. Metodologia Cientifica. $5^{\circ}$ ed. São Paulo: Afiliada, 2003.

CHIAVENATO, Idalberto. Gestão de Pessoas. $2^{\circ}$ ed. Rio de Janeiro: Campus, 2005.

DENCKER, Ada de Freitas Maneti. Métodos e Técnicas de pesquisa em turismo. $5^{\circ}$ ed. Futura,.2001.

DUTRA, Joel Souza. Gestão de Pessoas: modelo, processo, tendências e perspectivas. $1^{\circ}$ ed. São Paulo, 2002.

GALLOPIN, Gilberto. The abstract concept of environment. J. General Systems. 1981.

LIMONGI-FRANÇA, Ana Cristina. Qualidade de vida no trabalho - QVT. $2^{\circ}$ ed. São Paulo: Atlas S.A, 2004.

MASLOW, A.H. The theory of human motivation. Psychological Review. 1943.

ORGANIZAÇÃO MUNDIAL DE TURISMO; NETZ, Sandra (Trad). Guia de Desenvolvimento do Turismo Sustentável. Porto Alegre: Bookman, 2003.

ROSSI, Ana Maria Rossi; PERREWÉ, Pámela I.; SAUTER, Stiven I. Stress e Qualidade de Vida no Trabalho. --: Atlas, 2005

SALANOVA, M.;HONTANGAS, P.; PIERRÓ, J. W. Motivation Laboral. Madrid: Síntesis.1996.

SIQUEIRA, Mirlene Maria Matias; GOMIDE JUNIOR, Sinésio. Vínculos do Indivíduo com o Trabalho e com a Organização. $1^{\circ} \mathrm{ed}$. Porto Alegre: Artmed, 2004.

SPÉZIA, Domingos Sávio. Metodologia de Pesquisa. Brasília. 2006.

ZANELLI, José Carlos; BORGES-ANDRADE, Jairo Eduardo; BASTOS, Antonio V. Bitencourt.Psicologia, organizações e trabalho no Brasil.São Paulo:Artmed, 2004. 


\section{APÊNDICES}

APÊNDICE 1 - Questionário aplicado ao Gerente de RH da EMBRATUR

1. Foi feito marketing interno do programa de qualidade de vida na EMBRATUR? Quais as peças como foi feito?

RESPOSTA: É feito um acompanhamento, principalmente em relação à ginástica laboral, onde existiu uma pesquisa para saber as necessidades dos funcionários. $O$ projeto foi elaborado juntamente com a UnB.

\section{Todos os funcionários da organização são convidados a participar?}

(Desde gerentes e diretores até serventes)

RESPOSTA: Os projetos foram criados para atender todos os colaboradores da EMBRATUR: funcionários, terceirizados, contratados diretores, presidência, serventes.

3. É possível perceber melhoria na produtividade dos funcionários após a implantação do QVT ?

RESPOSTA: Com certeza. O servidor trabalha com mais afinco, se sente mais valorizado pela empresa, e tudo isso o motiva ao trabalho, aumentando a produtividade.

\section{A Presidência/ diretoria participa ativamente e acredita no programa?}

RESPOSTA: Com certeza. A maioria das benfeitorias dos programas partem deles; eles dão o sinal e o RH corre atrás da construção das ações.

\section{Como é a participação do RH no Projeto??}

RESPOSTA: O RH é responsável por todos os projetos, desde a criação como acompanhamentos e resultados. No caso da ginástica laboral e das aulas de idiomas é feito um acompanhamento através de relatórios trimestrais. Nas demais atividades é feito um acompanhamento geral, e verificar se há necessidade de mudança de horário, de professor, se os funcionários estão satisfeitos.

\section{Você pessoalmente participa das atividades promovidas?}

RESPOSTA: Participo apenas da laboral. 
7. O programa é renovado de acordo com as necessidades do funcionário e da empresa? Como funciona este processo?

RESPOSTA: Sim, sempre que possível são implantadas novas ações. Porém há dificuldade pela falta de verba. Existem muitas ações que não foram colocadas em prática.

8. Você acha que vale a pena o investimento financeiramente para realizar este programa?

RESPOSTA: Com certeza. Não só é importante, como é uma obrigação. Ajuda no relaxamento, previne riscos físicos, ajuda no entrosamento. Uma parte do orçamento é para fortalecer e aprimorar a qualidade e capacitação do funcionário. 
APÊNDICE 2 - Questionário aplicado aos Gerentes das Área da EMBRATUR

1. Os funcionários desta área foram convidados a participar do QVT? RESPOSTA 1: Sim.

RESPOSTA 2: Sim.

2. O convite foi convincente para os funcionários na sua percepção?

RESPOSTA 1: Sim e não. Há dedicação dos instrutores em convencer os participantes, mas há resistência dos funcionários, poucos (sic), devido à abordagem, horários e outras restrições pessoais.

RESPOSTA 2: Sim, sempre vejo os funcionários participando.

3. É possível perceber uma melhoria no relacionamento entre os funcionários após a implantação da QVT?

RESPOSTA 1: Não diretamente relacionada à QVT.

RESPOSTA 2: Sim, os funcionários estão bem mais entrosados.

4. É possível perceber maior motivação e produtividade dos funcionários depois da implantação do QVT?

RESPOSTA 1: Não diretamente relacionada à QVT.

RESPOSTA 2: Não exatamente. Os funcionários estão mais relaxados, mais isso não influencia a produtividade.

5. O programa é renovado de acordo com as necessidades do funcionário e da empresa? Como funciona este processo?

RESPOSTA 1: Desconheço o assunto.

RESPOSTA 2: Não sei informar.

6. É possível perceber diferenças no comportamento dos funcionários que praticam as atividades de QVT e os que não praticam? Quais são essas diferenças?

RESPOSTA 1: Nunca percebi.

RESPOSTA 2: Não. 
7. Você participa das ações? Você acha que a sua participação importante? Por quê?

RESPOSTA 1: Às vezes, quando tenho tempo.

RESPOSTA 2: Eu não tenho tempo para participar, mas os funcionários da área praticam.

8. Você tem alguma sugestão de ação ou melhoria para o QVT?

RESPOSTA 1: Variar o ambiente, e tentar atividades ao ar livre.

RESPOSTA 2: Não.

9. Você acha que vale a pena o investimento financeiro para realizar este programa?

RESPOSTA 1: Sim, desde que os haja um acompanhamento da participação dos funcionários.

RESPOSTA 2: Sim. 
APÊNDICE 3 - Questionário aplicado aos funcionários formadores de opinião, que tenham mais tempo de casa, ou grande influência e relacionamento com os grupos na EMBRATUR

\section{Você participa de quantas atividades do QVT?}

RESPOSTA 1: A. Aula laboral, aula de inglês, aniversariantes do mês. Não participa da fisioterapia, já que nunca sentiu dor. B. Aula laboral, aniversariantes do mês.

RESPOSTA 2: Aula laboral, aniversariantes do mês.

RESPOSTA 3: Aula laboral, aniversariante do mês, massagens, consulta do fisioterapeuta, aula de espanhol.

RESPOSTA 4: Só laboral, três vezes por semana.

RESPOSTA 5: Laboral, não participa da fisioterapia, pois não sentiu necessidade.

RESPOSTA 6: Apenas laboral.

RESPOSTA 7: Nenhum. Não tenho tempo.

RESPOSTA 8: Nenhum. Acho perda de tempo. Enquanto estaria praticando poderia estar resolvendo alguma outra coisa.

RESPOSTA 9: Palestras. Fora do horário de trabalho, não tem tempo disponível para trabalhar e praticar as ações. Extrapolaria meu horário de trabalho.

RESPOSTA 10: Sim, de acordo com meus horários procuro praticar todas as ações implantadas pela a empresa: aniversariantes do mês, aulas laborais, palestras, confraternizações em geral, aula de idiomas, massagem, fisioterapia.

\section{Você percebe benefícios pessoais ao participar dessas atividades?}

RESPOSTA 1: Sim, Prevenção de LER, DORT, humor.

RESPOSTA 2: Sim, é uma via de duas mãos, é um investimento.

RESPOSTA 3: Sim, os funcionários se sentem mais relaxados.

RESPOSTA 4: Sim, previne complicações físicas. 
RESPOSTA 5: Sim, apenas o entrosamento.

RESPOSTA 6: Com certeza é benéfico, além de dar uma maior disposição recebemos maiores informações sobre ergonomia.

RESPOSTA 7: Sim

RESPOSTA 8: Não

RESPOSTA 9: Sim

RESPOSTA 10: Sim

\section{Você percebe melhoria na produtividade de seus colegas de trabalho que participam do QVT?}

RESPOSTA 1: Sim. O funcionário se sente mais relaxado, fisicamente e psicologicamente, influenciando na motivação para trabalhar.

RESPOSTA 2: Sim. A empresa esta investindo na melhoria do ambiente, ajudando para que o funcionário se sinta melhor para trabalhar.

RESPOSTA 3: Sim, ajuda na pressão dos prazos,

RESPOSTA 4: Não, as ações apenas ajudam socialmente, não na produtividade.

RESPOSTA 5: Sim, após participar das ações da QVT tenho um melhor rendimento durante o expediente.

RESPOSTA 6: Não.

RESPOSTA 7: Não, a produtividade se dá conta pelo ambiente de trabalho.

RESPOSTA 8: Não.

RESPOSTA 9: Sim, principalmente os que fazem fisioterapia.

RESPOSTA 10: Sim, nos sentimos valorizados pela empresa, e trabalhamos com mais vontade.

\section{Você acha que você e seus colegas se sentem satisfeitos com as} atividades propostas pelo QVT?

RESPOSTA 1: Sim. 
RESPOSTA 2: Sim, gostam.

RESPOSTA 3: Sim. Porém, quem mais precisa - presidência, diretores, coordenadores -, não praticam.

RESPOSTA 4: Não, acho que os diretores não se sentem a vontade para participar. RESPOSTA 5: Não.

RESPOSTA 6: Sim. A maioria gosta e se dispõe a participar.

RESPOSTA 7: Sim.

RESPOSTA 8: Alguns.

RESPOSTA 9: Nem todos. Por exemplo, os diretores normalmente estão trabalhando, acho que eles não acham tão importante.

RESPOSTA 10: Sim.

\section{Você acha que a participação no projeto ajuda a relação entre os demais funcionários?}

RESPOSTA 1: Sim. União entre os departamentos.

RESPOSTA 2: Sim. Até os serventes participam.

RESPOSTA 3: Sim. Principalmente nas festas de confraternização.

RESPOSTA 4: Sim. Vivemos diariamente oito horas por dia com nossos colegas, viramos uma família, e é importante estar em harmonia com eles. Essas ações ajudam na melhoria dos relacionamentos

RESPOSTA 5: Sim.

RESPOSTA 6: Sim.

RESPOSTA 7: Não vejo ligação.

RESPOSTA 8: Não.

RESPOSTA 9: Sim. Inclusive poderia haver uma maior interação no setor se os diretores e coordenadores participassem.

RESPOSTA 10: Certamente. A interação entre os participantes é imediata e descontraída. 
6. O programa é renovado de acordo com as necessidades do funcionário e da empresa?

RESPOSTA 1: Não.

RESPOSTA 2: Não. O projeto é imposto, não existe um estudo para reconhecer as necessidades dos funcionários.

RESPOSTA 3: Não.

RESPOSTA 4: Sim, sempre passam fichas de avaliação.

RESPOSTA 5: O RH procura passar um questionário para verificar a satisfação dos funcionários.

RESPOSTA 6: Não.

RESPOSTA 7: Não.

RESPOSTA 8: Nunca percebi.

RESPOSTA 9: Não.

RESPOSTA 10: RH fez uma pesquisa antes de implementar as ações.

7. É possível perceber diferenças no comportamento dos funcionários que praticam as atividades de QVT e os que não praticam? Quais são essas diferenças?

RESPOSTA 1: Sim.

RESPOSTA 2: Não. Sempre vejo todos praticando.

RESPOSTA 3: Sim. O departamento de marketing não pratica, e normalmente eles parecem estar mais estressados.

RESPOSTA 4: Sim. Normalmente os diretores não participam, e normalmente podemos percebem um maior cansaço.

RESPOSTA 5: Sim apenas na parte física, em questão de relaxamento não.

RESPOSTA 6: Não.

RESPOSTA 7: Não.

RESPOSTA 8: Não consigo identificá-las. 
RESPOSTA 9: Sim. Eu particularmente noto que os dias que eu pratico me sinto mais motivada para trabalhar, e nos dias que não pratico sou tomada pela preguiça. RESPOSTA 10: Sim. É visível uma maior disposição e descontração dos que participam.

\section{Você tem alguma sugestão de ação ou melhoria para o QVT?}

RESPOSTA 1: Chefes de área participarem, juntamente com os demais funcionários.

RESPOSTA 2: Acompanhamento do RH.

RESPOSTA 3: Sim. Cursos de capacitação. Um local exclusivo para realização das aulas laboral.

RESPOSTA 4: Talvez um convite direto aos diretores.

RESPOSTA 5: Para ajudar a interação dos funcionários, uma maior participação dos coordenadores.

RESPOSTA 6: Sim. Aulas de loga.

RESPOSTA 7: Não. A EMBRATUR é uma mãe. Sempre procura estar presente.

RESPOSTA 8: Não. A EMBRATUR já faz a parte dela. O aumento das ações pode atrapalhar a produtividade.

RESPOSTA 9: Participação os diretores.

RESPOSTA 10: Maior investimento financeiro.

\section{Você acha que vale a pena o investimento financeiro para realizar este programa?}

RESPOSTA 1: Sim. É uma obrigação da empresa, pois, ao investir na parte de recursos humanos, a EMBRATUR mostra a valoração dos seus funcionários, e estará investindo nela própria.

RESPOSTA 2: Não. 
RESPOSTA 3: Sim. A QVT é uma via de mão dupla. Enquanto cuida dos funcionários, leva maior produtividade para empresa.

RESPOSTA 4: Sim, com certeza.

RESPOSTA 5: Sim.

RESPOSTA 6: Sim.

RESPOSTA 7: Sim.

RESPOSTA 8: Não.

RESPOSTA 9: Sim.

RESPOSTA 10: Sim, certamente. Afinal, essas atividades trazem ânimo, bomhumor, descontração e interatividade entre os funcionários. 


\section{APÊNDICE 4 - Questionário quantitativo com os funcionários da EMBRATUR}

1. Você conhece o programa QVT - Qualidade de vida no Trabalho da Embratur:
1. ( ) Sim;
2. ( ) Mais ou menos;
3. ( )Não.

2. Quanto às atividades propostas pelo programa da QVT:

1. ( ) As atividades são interessantes para os funcionários;

2. ( ) As atividades são pouco interessantes para os funcionários ;

3. ( ) As atividades são indiferentes para os funcionários;

4. ( ) As atividades não agradam aos funcionários;

5. ( ) Não conheço as atividades.

3. Marque qual a atividade que você mais gosta de participar: (marque apenas uma resposta)
1. ( )Ginástica laboral;
2. ( ) Curso de idiomas;
3. ( ) Massagens;
4. ( )Consulta com fisioterapeuta; 5. ( ) Palestras;
6. ( ) Confraternização em datas comemorativas.

4. O programa ajuda em: (marque quantos itens desejar)
1. ( ) Produtividade; 2. ( ) Motivação;
3. ( ) Relaxamento;

4. ( )Integração das pessoas; 5. ( )Não ajuda em nada.

5. Quanto à sua participação no programa da QVT:

1. ( ) Participo sempre;

2. ( ) Participo eventualmente;

3. ( ) Não participo pois não tenho tempo;

4. ( ) Não participo pois não me agrada.

6. Quanto ao investimento financeiro no programa QVT?

1. ( ) O investimento vale à pena pelos resultados alcançados

2. ( ) O investimento não vale à pena pelos resultados alcançados

7. Sexo:
1. ( ) Feminino;
2. ( ) Masculino.

8. Idade? anos.

9. Seu vínculo com a EMBRATUR:
1. ( ) Funcionário;
2. ( ) Terceirizados;
3. ( ) Estagiário.

10. Departamento onde trabalha:
1. ( ) Eventos;
2. ( ) Orçamentos;
3. ( ) Marketing.
4. ( ) R.H.
5. ( ) Outro, qual?

11. Nível hierárquico?
1. ( ) Diretor;
2. ( ) Gerente;
3. ( ) Operacional
4. ( ) Outro,
Qual?

12. Tempo de serviço na EMBRATUR? anos.

13. Por favor, coloque sugestões de melhoria para o QVT da EMBRATUR no verso desta folha: 


\section{ANEXOS}

ANEXO 1 - Decreto no 4.672, de 16 de abril de 2003.

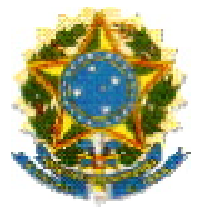

\section{Presidência da República Casa Civil Subchefia para Assuntos Jurídicos}

DECRETO № 4.672, DE 16 DE ABRIL DE 2003.

Aprova a Estrutura Regimental e o Quadro Demonstrativo dos Cargos em Comissão e das Funções Gratificadas da EMBRATUR - Instituto Brasileiro de Turismo, e dá outras providências.

O PRESIDENTE DA REPÚBLICA, no uso das atribuições que lhe confere o art. 84, incisos IV e VI, alínea "a", da Constituição, e tendo em vista disposto no art. 50 da Medida Provisória no 103 , de $1^{\text {o }}$ de janeiro de 2003 ,

\section{DECRETA:}

Art. 1ㅇ Ficam aprovados, na forma dos Anexos I e II a este Decreto, a Estrutura Regimental e o Quadro Demonstrativo dos Cargos em Comissão e das Funções Gratificadas da EMBRATUR Instituto Brasileiro de Turismo.

Art. 2o Em decorrência do disposto no art. 1o, ficam remanejados, na forma do Anexo III a este Decreto, os seguintes cargos em comissão do Grupo-Direção e Assessoramento Superiores - DAS:

I - da Secretaria de Gestão, do Ministério do Planejamento, Orçamento e Gestão para a EMBRATUR, um DAS 101.3; um DAS 102.4; e três DAS 102.3; e

II - da EMBRATUR para a Secretaria de Gestão, do Ministério do Planejamento, Orçamento e Gestão, quatro DAS 101.4; três DAS 101.2; dois DAS 101.1; dois DAS 102.2; dois DAS 102.1; onze FG-1; doze FG-2; e quatorze FG-3.

Art. 3o Os apostilamentos decorrentes da aprovação da Estrutura Regimental de que trata o art. 1 ㅇ deverão ocorrer no prazo de vinte dias, contado da data de publicação deste Decreto.

Parágrafo único. Após os apostilamentos previstos no caput, o Presidente da EMBRATUR fará publicar no Diário Oficial da União, no prazo de trinta dias, contado da data de publicação deste Decreto, relação nominal dos titulares dos cargos em comissão do Grupo-Direção e Assessoramento Superiores - DAS a que se refere o Anexo II, indicando, inclusive, o número de cargos vagos, sua denominação e respectivo nível.

Art. $4^{\circ}$ O regimento interno da EMBRATUR será aprovado pelo Ministro de Estado do Turismo e publicado no Diário Oficial da União, no prazo de sessenta dias, contado da data de publicação deste Decreto.

Art. $5^{\circ}$ Este Decreto entra em vigor na data de sua publicação. 
Art. 6 Fica revogado o Decreto ํㅜ 2.079, de 26 de novembro de 1996.

Brasília, 16 de abril de 2003; 182ㅇ da Independência e 115º da República.

LUIZ INÁCIO LULA DA SILVA

Guido Mantega

Walfrido Silvino dos Mares Guia Neto

Este texto não substitui o publicado no D.O.U. de 17.4.2003

ANEXO I

ESTRUTURA REGIMENTAL DA

EMBRATUR - INSTITUTO BRASILEIRO DE TURISMO

CAPÍTULO I

DA NATUREZA, SEDE E FINALIDADE

Art. 1 A EMBRATUR - Instituto Brasileiro de Turismo, autarquia especial, criada nos termos do art. 11 do Decreto-Lei no 55, de 18 de novembro de 1966, vinculada ao Ministério do Turismo, com sede e foro em Brasília, Distrito Federal, e jurisdição em todo o território nacional.

Art. 2 A EMBRATUR tem por finalidade apoiar a formulação e coordenar a implementação da Política Nacional de Turismo, como fator de desenvolvimento social e econômico, cabendo-lhe, ainda, executar as ações relativas:

I - à promoção e marketing de ofertas de destinos, produtos e serviços turísticos do Brasil nos mercados nacional e internacional;

II - ao incremento dos fluxos de turista nacionais e internacionais em suas várias modalidades;

III - às avaliações de critérios, parâmetros e métodos para o controle e consolidação da base de dados gerenciais e estatísticos do turismo nacional; e

IV - ao implemento, controle e supervisão de ações para o incremento da qualidade e competitividade do turismo nacional.

\section{CAPÍTULO II}

\section{DA ESTRUTURA ORGANIZACIONAL}

Art. 3 A EMBRATUR tem a seguinte estrutura organizacional:

I - órgãos de assistência direta e imediata ao Presidente:

a) Gabinete;

b) Assessoria de Comunicação Social; e

c) Procuradoria-Jurídica;

II - órgãos seccionais: 

a) Auditoria Interna; e
b) Departamento de Administração e Finanças;
III - órgãos específicos singulares:
a) Departamento de Turismo de Lazer e Incentivos;
b) Departamento de Marketing e Relações Institucionais;
c) Departamento de Turismo de Negócios e Eventos; e
d) Departamento de Estudos e Pesquisas.

\title{
CAPÍTULO III
}

\section{DA DIREÇÃO E NOMEAÇÃO}

Art. 4ํㅡ A EMBRATUR é dirigida por um Presidente e cinco Diretores, indicados pelo Ministro de Estado do Turismo e nomeados pelo Presidente da República.

$\S 1$ 을 A nomeação do Procurador Jurídico deverá ser precedida da prévia anuência do Advogado-Geral da União.

$\S 2$ o A nomeação do Auditor-Chefe será submetida pelo Presidente da EMBRATUR à aprovação da Controladoria-Geral da União.

$\S 3$ 응 Os demais cargos em comissão e funções gratificadas serão providos na forma da legislação vigente.

\author{
CAPÍTULO IV
}

\section{DAS COMPETÊNCIAS}

\section{Seção I}

\section{Dos Órgãos de Assistência Direta e Imediata ao Presidente}

\section{Art. 5으 Ao Gabinete compete:}

I - assistir ao Presidente da EMBRATUR em sua representação política e social e incumbir-se do preparo e despacho do seu expediente pessoal; e

II - exercer outras competências que Ihe forem cometidas pelo Presidente da EMBRATUR.

Art. 6o À Assessoria de Comunicação Social compete assessorar o Presidente nos assuntos pertinentes a imprensa e a relações públicas.

Art. 7o À Procuradoria-Jurídica, na qualidade de órgão executor da Procuradoria-Geral Federal, compete:

I - representar judicial e extrajudicialmente a EMBRATUR; 
II - exercer atividades de consultoria e assessoramento jurídicos aos órgãos da EMBRATUR, aplicando-se, no que couber, o disposto no art. 11 da Lei Complementar no 73, de 10 de fevereiro de 1993;

III - fixar a interpretação da Constituição, das leis, dos tratados e dos demais atos normativos a ser uniformemente seguida em suas áreas de atuação e coordenação, quando não houver orientação normativa do Advogado-Geral da União;

IV - a apuração da liquidez e certeza dos créditos, de qualquer natureza, inerentes às atividades da EMBRATUR, inscrevendo-os em dívida ativa, para fins de cobrança amigável ou judicial; e

V - examinar, prévia e conclusivamente, no âmbito da EMBRATUR:

a) os textos de editais de licitação, bem como os dos respectivos contratos ou instrumentos congêneres, a serem publicados e celebrados;

b) os atos pelos quais se vá reconhecer a inexigibilidade ou decidir a dispensa de licitação;

C) propostas, estudos, projetos, anteprojetos e minutas de atos normativos de interesse da EMBRATUR; e

d) os processos e documentos que envolvam matérias referentes a assuntos de cunho administrativo ou judicial.

\section{Seção II}

\section{Dos Órgãos Seccionais}

Art. 8o À Auditoria Interna compete examinar a conformidade legal dos atos de gestão orçamentário-financeiro, patrimonial, de pessoal, dos demais sistemas administrativos e operacionais, e especificamente:

I - verificar a regularidade nos controles internos e externos, especialmente daqueles referentes à realização da receita e da despesa, bem como da execução financeira de contratos, convênios, acordos e ajustes firmados pela EMBRATUR;

II - promover inspeções regulares para verificar a execução física e financeira dos programas, projetos e atividades e executar auditorias extraordinárias determinadas pelo Presidente;

III - examinar e emitir parecer sobre a prestação de conta anual da entidade e tomadas de contas especiais; e

IV - propor ações de forma a garantir a legalidade dos atos e o alcance dos resultados, contribuindo para a melhoria da gestão.

Art. 9으 Ao Departamento de Administração e Finanças compete coordenar e controlar a execução das atividades relacionadas aos Sistemas de Pessoal Civil da Administração Federal SIPEC, de Organização e Modernização Administrativa - SOMAD, de Administração dos Recursos de Informação e Informática - SISP, de Serviços Gerais - SISG, de Planejamento e de Orçamento Federal, de Contabilidade Federal e de Administração Financeira Federal.

\section{Seção III}

\section{Dos Órgãos Específicos Singulares}

Art. 10. Ao Departamento de Turismo de Lazer e Incentivos compete: 
I - identificar e analisar as condições de competitividade dos produtos turísticos brasileiros;

II - estabelecer parâmetros que possibilitem a identificação de segmentos de produtos turísticos;

III - identificar os mercados existentes e potenciais, bem como formas alternativas de comercialização dos produtos turísticos brasileiros; e

IV - desenvolver estratégias para a distribuição dos produtos turísticos nos canais de comercialização.

Art. 11. Ao Departamento de Marketing e Relações Institucionais compete:

I - propor, coordenar, supervisionar e controlar a execução da política de marketing, de promoção e propaganda do turismo brasileiro no País e no exterior; e

II - coordenar as relações entre a EMBRATUR, entidades e instituições públicas e privadas; e

III - articular, sob a coordenação do Ministério do Turismo, com o Congresso Nacional nos assuntos relacionados à EMBRATUR.

Art. 12. Ao Departamento de Turismo de Negócios e Eventos compete:

I - coordenar as ações para incrementar e desenvolver a participação do segmento de negócios e eventos no turismo brasileiro;

II - coordenar a participação dos segmentos turísticos brasileiros de negócios e eventos e de lazer e incentivos em eventos e atividades promocionais voltadas ao incremento do fluxo turístico no território brasileiro e no mercado internacional; e

III - ampliar a participação do Brasil no mercado internacional do turismo, no segmento de negócios e eventos.

Art. 13. Ao Departamento de Estudos e Pesquisas compete:

I - propor, coordenar, supervisionar e apoiar a realização de estudos, pesquisas, análises, levantamentos e sistematização de dados estatísticos sobre o setor turístico, com o objetivo de orientar as políticas públicas e subsidiar a tomada de decisão da iniciativa privada;

II - criar base de dados de informações gerenciais sobre a oferta e demanda turística para apoiar a tomada de decisão nas áreas pública e privada;

III - realizar estudos e pesquisas sobre oportunidades de investimentos na área de turismo; e

IV - interagir com instituições correlatas em nível nacional e internacional, buscando o constante aprimoramento da área de pesquisa e informação turística.

CAPÍTULO V

\section{DAS ATRIBUIÇÕES DOS DIRIGENTES}

Art. 14. Ao Presidente incumbe:

I - planejar, dirigir, coordenar e controlar a execução das atividades da EMBRATUR; 
II - orientar e coordenar o funcionamento geral da EMBRATUR em todos os setores de suas atividades, zelando pelo fiel cumprimento da Lei № 8.181, de 1991, assim como da política geral e dos planos, programas e projetos da Autarquia;

III - firmar, em nome da EMBRATUR, contratos, convênios, acordos, ajustes e outros instrumentos similares; e

IV - praticar os atos necessários à gestão técnica, administrativa, orçamentária e financeira da EMBRATUR.

Art. 15. Aos Diretores, ao Procurador-Jurídico, ao Auditor-Chefe, ao Chefe de Gabinete, ao Chefe da Assessoria e aos demais dirigentes incumbe planejar, dirigir e coordenar a execução das atividades afetas as suas respectivas unidades organizacionais, bem como exercer outras atribuições que lhes forem cometidas pelo Presidente da EMBRATUR.

\section{CAPÍTULO VI}

\section{DAS DISPOSIÇÕES GERAIS}

Art. 16. O regimento interno definirá o detalhamento das unidades integrantes da Estrutura Regimental da EMBRATUR, as competências das respectivas unidades e as atribuições de seus dirigentes. 
ANEXO 2 - Quadro demonstrativo dos cargos em comissão e das funções gratificadas da EMBRATUR

\begin{tabular}{|c|c|c|c|}
\hline UNIDADE & $\begin{array}{l}\text { CARGO/ } \\
\text { FUNÇÃO }\end{array}$ & $\begin{array}{l}\text { DENOMINAČ̃̃O } \\
\text { CARGO/FUNÇÃO }\end{array}$ & $\begin{array}{c}\text { DAS/ } \\
\text { FG }\end{array}$ \\
\hline & 1 & Presidente & 101.6 \\
\hline & 2 & Assessor & 102.4 \\
\hline \multirow{7}{*}{ GABINETE } & 1 & Chefe de Gabinete & 101.4 \\
\hline & 3 & Assessor Técnico & 102.3 \\
\hline & 3 & Assistente & 102.2 \\
\hline & 2 & Assistente Técnico & 102.1 \\
\hline & 1 & & FG-1 \\
\hline & 1 & & FG-2 \\
\hline & 1 & & FG-3 \\
\hline \multicolumn{4}{|l|}{ Assessoria de Comunicação } \\
\hline \multirow[t]{3}{*}{ Social } & 1 & Chefe da Assessoria & 101.4 \\
\hline & 2 & Assessor Técnico & 102.3 \\
\hline & 1 & Assistente & 102.2 \\
\hline PROCURADORIA-JURÍDICA & 1 & Procurador-Jurídico & 101.4 \\
\hline Divisão & 2 & Chefe & 101.2 \\
\hline AUDITORIA INTERNA & 1 & Auditor-Chefe & 101.4 \\
\hline Divisão & 2 & Chefe & 101.2 \\
\hline \multicolumn{4}{|l|}{ DEPARTAMENTO DE } \\
\hline \multirow[t]{4}{*}{ ADMINISTRAÇÃO E FINANÇAS } & 1 & Diretor & 101.5 \\
\hline & 1 & Assistente Técnico & 102.1 \\
\hline & 1 & & FG-1 \\
\hline & 1 & & FG-2 \\
\hline
\end{tabular}




\begin{tabular}{|c|c|c|c|}
\hline & 1 & & FG-3 \\
\hline Coordenação-Geral de Administração & 1 & Coordenador-Geral & 101.4 \\
\hline Divisão & 3 & Chefe & 101.2 \\
\hline Serviço & 4 & Chefe & 101.1 \\
\hline Coordenação-Geral de Finanças & 1 & Coordenador-Geral & 101.4 \\
\hline Divisão & 3 & Chefe & 101.2 \\
\hline Serviço & 4 & Chefe & 101.1 \\
\hline Coordenação-Geral de Informação & 1 & Coordenador-Geral & 101.4 \\
\hline Divisão & 3 & Chefe & 101.2 \\
\hline \multicolumn{4}{|l|}{ DEPARTAMENTO DE TURISMO DE } \\
\hline \multirow[t]{2}{*}{ LAZER E INCENTIVOS } & 1 & Diretor & 101.5 \\
\hline & 1 & Assistente Técnico & 102.1 \\
\hline \multicolumn{4}{|l|}{ Coordenação-Geral de Apoio à } \\
\hline Comercialização & 1 & Coordenador-Geral & 101.4 \\
\hline Divisão & 3 & Chefe & 101.2 \\
\hline $\begin{array}{l}\text { Coordenação-Geral de Segmentação e } \\
\text { Produtos }\end{array}$ & 1 & Coordenador-Geral & 101.4 \\
\hline Divisão & 2 & Chefe & 101.2 \\
\hline Serviço & 1 & Chefe & 101.1 \\
\hline Coordenação-Geral de Novos Mercados & 1 & Coordenador-Geral & 101.4 \\
\hline Divisão & 2 & Chefe & 101.2 \\
\hline \multicolumn{4}{|l|}{ DEPARTAMENTO DE MARKETING E } \\
\hline \multirow[t]{3}{*}{ RELAÇOES INSTITUCIONAIS } & 1 & Diretor & 101.5 \\
\hline & 2 & Assistente Técnico & 102.1 \\
\hline & 1 & Assessor Técnico & 102.3 \\
\hline Coordenação-Geral de Propaganda & 1 & Coordenador-Geral & 101.4 \\
\hline
\end{tabular}




\begin{tabular}{|c|c|c|c|}
\hline Divisão & 3 & Chefe & 101.2 \\
\hline Serviço & 1 & Chefe & 101.1 \\
\hline $\begin{array}{l}\text { Coordenação-Geral de Relações } \\
\text { Institucionais }\end{array}$ & 1 & Coordenador-Geral & 101.4 \\
\hline Divisão & 3 & Chefe & 101.2 \\
\hline \multicolumn{4}{|l|}{ DEPARTAMENTO DE TURISMO DE } \\
\hline \multirow[t]{2}{*}{ NEGÓCIOS E EVENTOS } & 1 & Diretor & 101.5 \\
\hline & 1 & Assessor Técnico & 102.3 \\
\hline Coordenação-Geral de Turismo de Eventos & 1 & Coordenador-Geral & 101.4 \\
\hline Divisão & 3 & Chefe & 101.2 \\
\hline $\begin{array}{l}\text { Coordenação-Geral de Eventos } \\
\text { Promocionais }\end{array}$ & 1 & Coordenador-Geral & 101.4 \\
\hline Coordenação & 1 & Coordenador & 101.3 \\
\hline Divisão & 1 & Chefe & 101.2 \\
\hline Serviço & 1 & Chefe & 101.1 \\
\hline $\begin{array}{l}\text { Coordenação-Geral de Turismo de } \\
\text { Negócios }\end{array}$ & 1 & Coordenador-Geral & 101.4 \\
\hline Divisão & 2 & Chefe & 101.2 \\
\hline Serviço & 1 & Chefe & 101.1 \\
\hline \multicolumn{4}{|l|}{ DEPARTAMENTO DE ESTUDOS E } \\
\hline \multirow[t]{2}{*}{ PESQUISAS } & 1 & Diretor & 101.5 \\
\hline & 1 & Assessor Técnico & 102.3 \\
\hline $\begin{array}{l}\text { Coordenação-Geral de Estudos E } \\
\text { Pesquisas }\end{array}$ & 1 & Coordenador-Geral & 101.4 \\
\hline Divisão & 3 & Chefe & 101.2 \\
\hline $\begin{array}{l}\text { Coordenação-Geral de Informações } \\
\text { Gerenciais }\end{array}$ & 1 & Coordenador-Geral & 101.4 \\
\hline Divisão & 2 & Chefe & 101.2 \\
\hline
\end{tabular}


ANEXO 3 - Quadro resumo de custos dos cargos em comissão e das funções gratificadas da EMBRATUR

\begin{tabular}{|c|c|c|c|c|c|}
\hline \multirow{2}{*}{ CóDIGO } & \multirow{2}{*}{$\begin{array}{c}\text { DAS- } \\
\text { UNITÁRIO }\end{array}$} & \multicolumn{2}{|c|}{ SITUAÇÃO ATUAL } & \multicolumn{2}{|c|}{ SITUAÇÃO NOVA } \\
\hline & & QTDE. & VALOR TOTAL & QTDE. & VALOR TOTAL \\
\hline DAS 101.6 & 6,15 & 1 & 6,15 & 1 & 6,15 \\
\hline DAS 101.5 & 5,16 & 5 & 25,80 & 5 & 25,80 \\
\hline DAS 101.4 & 3,98 & 21 & 83,58 & 17 & 67,66 \\
\hline DAS 101.3 & 1,28 & - & - & 1 & 1,28 \\
\hline DAS 101.2 & 1,14 & 40 & 45,60 & 37 & 42,18 \\
\hline DAS 101.1 & 1,00 & 14 & 14,00 & 12 & 12,00 \\
\hline DAS 102.4 & 3,98 & 1 & 3,98 & 2 & 7,96 \\
\hline DAS 102.3 & 1,28 & 5 & 6,40 & 8 & 10,24 \\
\hline DAS 102.2 & 1,14 & 6 & 6,84 & 4 & 4,56 \\
\hline DAS 102.1 & 1,00 & 8 & 8,00 & 6 & 6,00 \\
\hline \multicolumn{2}{|c|}{ SUBTOTAL 1} & 101 & 200,35 & 93 & 183,83 \\
\hline FG-1 & 0,20 & 13 & 2,60 & 2 & 0,40 \\
\hline FG-2 & 0,15 & 14 & 2,10 & 2 & 0,30 \\
\hline FG-3 & 0,12 & 16 & 1,92 & 2 & 0,24 \\
\hline \multicolumn{2}{|c|}{ SUBTOTAL 2} & 43 & 6,62 & 6 & 0,94 \\
\hline \multicolumn{2}{|c|}{ TOTAL (1+2) } & 144 & 206,97 & 99 & 184,77 \\
\hline
\end{tabular}


ANEXO 4 - Quadro de remanejamento de cargos da EMBRATUR

\begin{tabular}{|c|c|c|c|c|c|}
\hline \multirow[t]{2}{*}{ CÓDIGO } & \multirow{2}{*}{$\begin{array}{c}\text { DAS- } \\
\text { UNITÁRIO }\end{array}$} & \multicolumn{2}{|c|}{$\begin{array}{c}\text { DA SEGES/MP P/ A } \\
\text { EMBRATUR (a) }\end{array}$} & \multicolumn{2}{|c|}{$\begin{array}{l}\text { DA EMBRATUR P/ A } \\
\text { SEGES/MP (b) }\end{array}$} \\
\hline & & QTDE & VALOR TOTAL & QTDE & VALOR TOTAL \\
\hline DAS 101.4 & 3,98 & - & - & 4 & 15,92 \\
\hline DAS 101.3 & 1,28 & 1 & 1,28 & & \\
\hline DAS 101.2 & 1,14 & - & - & 3 & 3,42 \\
\hline DAS 101.1 & 1,00 & - & - & 2 & 2,00 \\
\hline DAS-102.4 & 3,98 & 1 & 3,98 & - & - \\
\hline DAS 102.3 & 1,28 & 3 & 3,84 & - & - \\
\hline DAS 102.2 & 1,14 & - & - & 2 & 2,28 \\
\hline DAS 102.1 & 1,00 & - & - & 2 & 2,00 \\
\hline \multicolumn{2}{|c|}{ SUBTOTAL 1} & 5 & 9,10 & 13 & 25,62 \\
\hline FG-1 & 0,20 & - & - & 11 & 2,20 \\
\hline FG-2 & 0,15 & - & - & 12 & 1,80 \\
\hline FG-3 & 0,12 & - & - & 14 & 1,68 \\
\hline \multicolumn{2}{|c|}{ SUBTOTAL 2} & - & - & 37 & 5,68 \\
\hline \multicolumn{2}{|c|}{ TOTAL } & 5 & 9,10 & 50 & 31,30 \\
\hline \multicolumn{2}{|c|}{$\begin{array}{l}\text { SALDO DO REMANEJAMENTO } \\
\qquad(a-b)\end{array}$} & - & - & -45 & $-22,20$ \\
\hline
\end{tabular}


ANEXO 5 - Figuras exemplificando a aplicação de programas de QVT

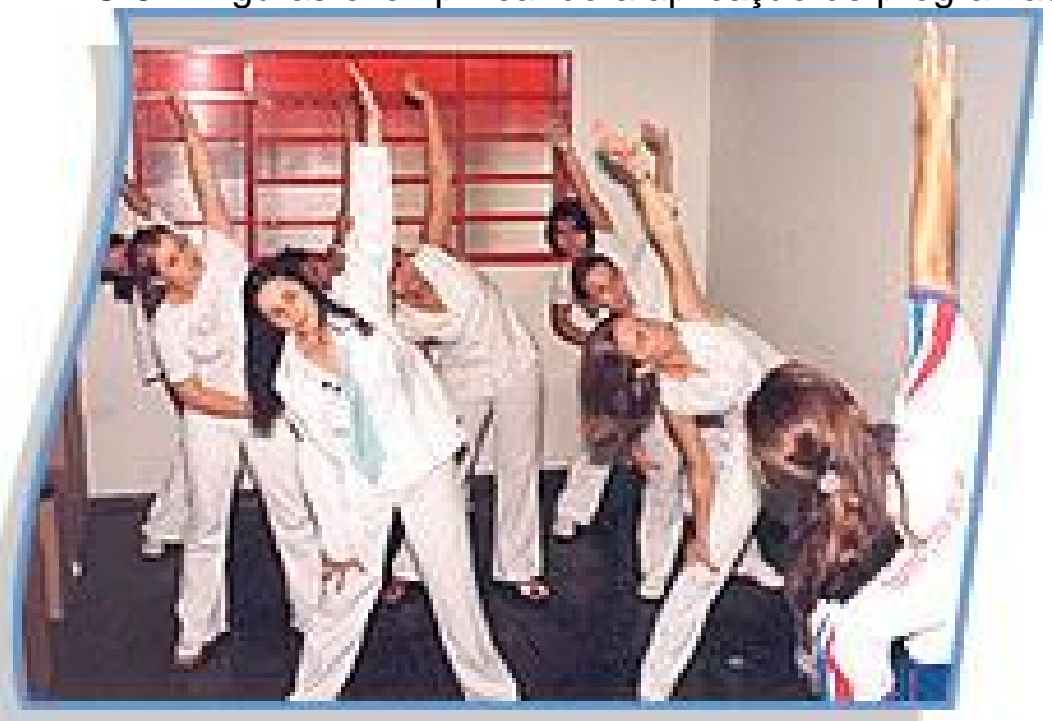

Figura 1: Ginástica Laboral

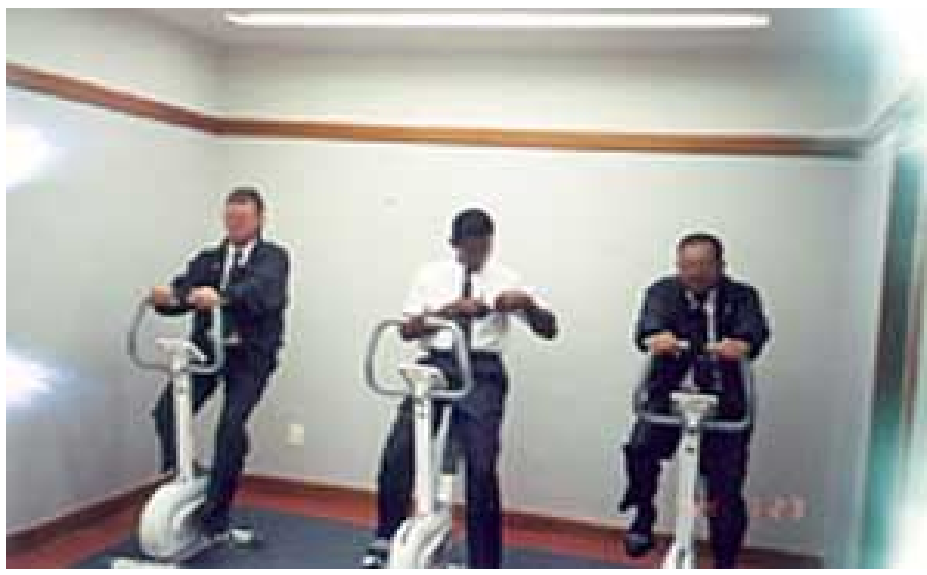

Figura 2: Ergometria

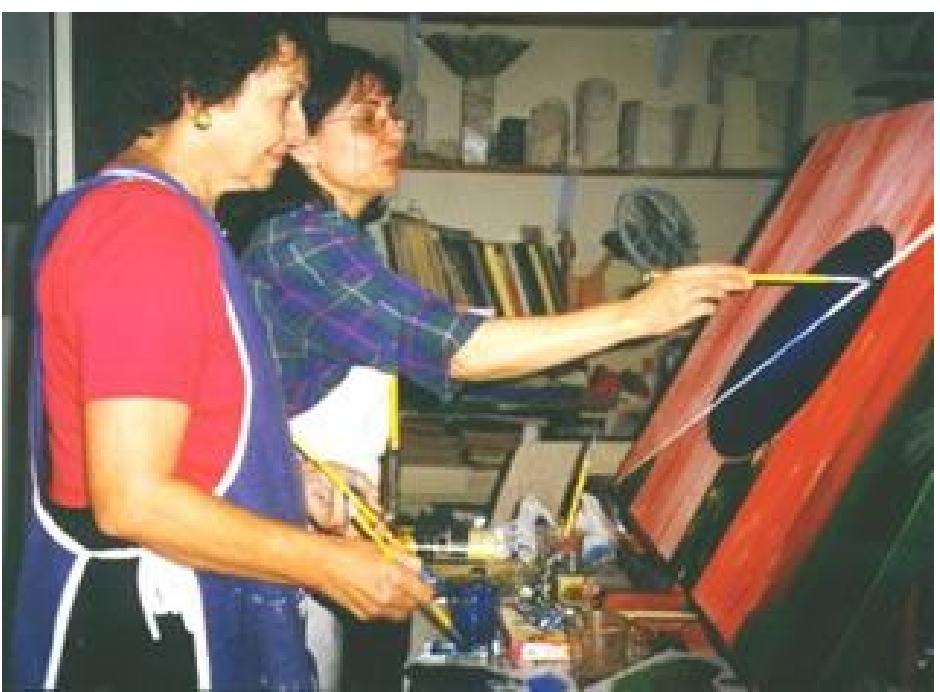

Figura 3: Aula de pintura 